\title{
ENERGY PROJECTS, SOCIAL LICENCE, PUBLIC ACCEPTANCE AND REGULATORY SYSTEMS IN CANADA: A WHITE PAPER*
}

John Colton, Kenneth Corscadden, Stewart Fast, Monica Gattinger, Joel Gehman, Martha Hall Findlay, Dylan Morgan, Judith Sayers, Jennifer Winter and Adonis Yatchew

\section{ACKNOWLEDGEMENTS}

The authors wish to note that this paper is not a work of consensus, but rather a collaborative effort to explore the topics of public acceptance and social licence and should not be considered reflective of each individual's personal viewpoint.

The authors have many people to thank for their contributions to this paper. In particular, thanks are owed to participants at the Canadian Network for Energy Policy Research and Analysis stakeholder workshop held in Calgary in January 2015, and Kaleidoscope Training and Consulting for their excellent facilitation of the workshop. We also wish to thank participants at the Canadian Network for Energy Policy Research and Analysis' Conference on Public Acceptance of Energy Projects held in Ottawa in September 2015 for their comments and discussion of the paper. We especially thank Blaine Favel, MarieJosé Fortin, Rowland Harrison, lan Lee and Herb Emery for reading and commenting on a draft version of the paper. Thanks are owed to Frankie Lau for his excellent logistical support during both the workshop and the conference, and to Kinga Starzyk-Dramowicz for her logistical support during the team's initial working meeting. We wish to thank Jordan Carlson and Sophie Lorefice for excellent research assistance. Last but not least, the author team would like to acknowledge Dylan Morgan's efforts in co-ordinating the monthly conference calls and compiling the various components of the paper into a single document.

The School of Public Policy is committed to the highest standards of academic integrity and objectivity. For that reason, we forthrightly disclose that funding for this research was received from the Energy Council of Canada, through its support as founding sponsor of the Canadian Network for Energy Policy Research and Analysis at the School of Public Policy, University of Calgary. We also wish to acknowledge the support of the Vice President of Research Office at the University of Calgary, for funding an Eyes High Postdoctoral Scholar for the Network, without which the research could not have taken place.

* This research was financially supported by the Government of Canada via a partnership with Western Economic Diversification. 


\section{SUMMARY}

It has become increasingly difficult in Canada to gain and sustain public acceptance of energy projects. Increased levels of protest, combined with traditional media and social media coverage of opposition, combine to suggest decreased public acceptance of energy projects. Decision-makers have responded accordingly, and a variety of energy projects have either been delayed or put on hold indefinitely. This is true for both conventional and renewable energy projects and in many different regions across the country. A number of proposed energy projects have recently faced opposition from various stakeholder groups. For instance, the decision of the Joint Review Panel for the Northern Gateway Pipeline is being challenged in Canada's court system. First Nations groups have issued an ultimatum to the Federal Government that it must choose between Site C (a proposed hydro dam) and liquefied natural gas development in B.C. Rapid expansion of wind energy projects in Ontario has engendered lengthy and costly appeals and the rise of an anti-wind social movement. In Nova Scotia, tidal energy development is being positioned as a new renewable energy option; gaining public acceptance is critical in light of recent opposition to wind energy development. As these experiences suggest, not only has the regulatory process become more contentious, but also an apparently new concept - social licence - has had popular appeal.

This white paper reports on the results of a year-long interdisciplinary collaboration aimed at identifying and summarizing extant research regarding social licence and related concepts, with a particular emphasis on understanding its implications for public acceptance of energy projects in Canada, and their related regulatory processes. In particular, this research addressed the following questions:

1. What is the history and scope of the term 'social licence', both in the context of energy project development and more generally? What are the strengths and limitations of this term? How does it help or hinder energy policy, regulatory debates and decision-making?

2. What are the similarities and differences between the notion of social licence and established concepts and other concepts or frameworks?

3. From the standpoint of public acceptance of energy projects, is Canada's regulatory system broken? From whose perspective? And what alternatives might be considered?

4. What are barriers to, and enablers of a licence within the regulatory process - legal, social or otherwise?

5. What role does social licence play in the larger picture: How valid is the concept of social licence? Can social licence actually stop a project, or determine the outcome of an election? Does it create a valuable dialogue about a project? When opposition to projects leads to the arrest of people breaching an injunction or violent confrontations, what role can social licence play in promoting an alternative approach?

In addition to a comprehensive look at the concepts of public acceptance and social licence and their applications to Canada, this white paper arrives at certain conclusions (Section 5) and makes recommendations (Section 6) for improving Canada's regulatory systems and improving public confidence in Canada's various energy-related regulatory agencies. For instance, as the federal government embarks on its agenda to amend the regulatory process, the research presented here can inform how the government can best carry out its mandate of reform while balancing the economic, environmental, political, social, and security-related issues pertinent to regulators, federal and provincial governments, industry, First Nations, environmental groups and the general public.

The appeal of the term "social licence" derives from the inclusivity and equitability that it seems to imply. But populist pressure for increased voice and regulatory or judicial intervention, arising out of a sense of disaffection or disenfranchisement, is hardly a novel phenomenon: historical context and 
the lessons learned therefrom are essential in evaluating the idea and situating the debate within a meaningful framework.

Social licence entails an additional layer of 'regulation', albeit an amorphous one. A central lesson of the 20th century experience is that regulation comes at a cost, and that excessive regulation and intervention can lead to paralysis and 'government failure'. The implication is that regulation should be relied upon where it is necessary, and should be implemented in sensible ways. One of the conclusions of this report is that public trust and confidence can be enhanced by rationalizing existing regulatory vehicles to reduce the common perception that decisions are sometimes politically motivated and ensuring that decisions are made at the right levels of government.

The institutionalization of social licence also has identifiable risks. It is likely to increase incentives for "rent-seeking behaviour." The threat of veto, or even obstruction, endows the affected group with leverage that can result in extraction of rents that are disproportionate to impacts. It also increases regulatory and political uncertainty associated with a given project, discouraging investment, or requiring returns higher than are merited by the inherent riskiness of the proposed undertaking.

The term "social licence" needs to be further analyzed, and, if used, used with care. The concept originated in the mining sector as the "social licence to operate," and as the concept has migrated to the energy sector, it appears to have broadened in scope so that its meaning has become unclear, amorphous and confusing. Other terms such as "acceptance," "support" or "public confidence" may be more appropriate in the energy sphere. Regulators, policy-makers and politicians should refrain from the use of these terms without a clear understanding of their implications.

Our specific recommendations include:

1. Governmental Coordination. Greater coordination of regulatory processes between the federal and provincial governments is required and should be directed towards enhancing beneficial outcomes for all affected stakeholders (Section 6.1).

2. Stakeholder Engagement. A consistent, transparent and rigorous system for identifying and reaching out to stakeholders is essential to regulatory efficiency and efficacy (Section 6.2).

3. Social Licence as a Concept. When it comes to energy development, the term "social licence" needs to be further analyzed, and, if used, used with care (Section 6.3).

4. First Nations. The federal and provincial governments should take ownership of this duty to consult and ensure that it is done in a comprehensive manner that has been set out by both domestic and international law (Section 6.4).

5. Changes to the NEB Act. An independent review of the changes to the NEB Act regarding time to consult and the list of those who can be consulted should be undertaken to ensure the NEB is unconstrained in its ability to regulate appropriately and has public confidence in its mandate and decisions (Section 6.5).

6. Make Broader Use of Information Gained during Assessment Processes. Energy regulators should consider mechanisms to report recurring concerns that are outside of the scope of their mandate (Section 6.6).

7. Compliance after Project Approval. There is a need for publicly available, timely and relevant data relating to the compliance and post-approval status of projects. Data should be placed on a government portal to increase accessibility to stakeholders (Section 6.7).

8. Cross-Examination in Regulatory Hearings. The extensiveness of permitted cross-examination, and indeed the entire regulatory proceeding, needs to be proportionate to the magnitude of the impacts of the ultimate decision (Section 6.8). 


\section{PROJETS ÉNERGÉTIQUES, CONTRAT SOCIAL, ACCEPTATION PUBLIQUE ET SYSTĖMES DE RÉGLEMENTATION AU CANADA : LIVRE BLANC*}

John Colton, Kenneth Corscadden, Stewart Fast, Monica Gattinger, Joel Gehman, Martha Hall Findlay, Dylan Morgan, Judith Sayers, Jennifer Winter et Adonis Yatchew

\section{REMERCIEMENTS}

Les auteurs souhaitent noter que le présent document n'est pas un ouvrage consensuel mais plutôt un effort de collaboration visant à explorer les sujets de l'acceptation publique et du contrat social. On ne devrait pas considérer qu'il représente le point de vue personnel de chaque individu.

Les auteurs ont de nombreuses personnes à remercier pour leurs contributions à cette étude. En particulier, nous tenons à remercier les participants à l'atelier des intervenants du Canadian Network for Energy Policy Research and Analysis qui s'est déroulé à Calgary en janvier 2015, ainsi que Kaleidoscope Training and Consulting pour leur excellent travail d'animation de cet atelier. Nous souhaitons également remercier les participants à la Canadian Network for Energy Policy Research and Analysis' Conference on Public Acceptance of Energy Projects, qui a eu lieu à Ottawa en septembre 2015, pour leurs commentaires et leur discussion de l'étude. Nous remercions spécialement Blaine Favel, Marie-Josée Fortin, Rowland Harrison, Ian Lee et Herb Emery pour avoir lu et commenté une version préliminaire de l'étude. Nos remerciements vont également à Frankie Lau pour son excellent soutien logistique pendant l'atelier et la conférence, ainsi qu'à Kinga Starzyk-Dramowicz pour son soutien logistique lors de la réunion de travail initiale de l'équipe. Nous tenons à remercier Jordan Carlson et Sophie Lorefice pour leur excellent travail d'aide à la recherche. Finalement, l'équipe d'auteurs tient à souligner les efforts de Dylan Morgan pour la coordination des conférences téléphoniques mensuelles et pour le regroupement des diverses composantes de l'étude en un document unique.

La School of Public Policy a à cœur les plus hautes normes d'intégrité et d'objectivité dans la recherche universitaire. C'est pour cette raison que nous déclarons ouvertement que le financement de cette recherche provient du Conseil canadien de l'énergie, grâce à son soutien en tant que commanditaire fondateur du Canadian Network for Energy Policy Research and Analysis de la School of Public Policy, Université de Calgary. 
Nous tenons également à souligner le soutien du vice-président du Bureau de recherche de l'Université de Calgary pour le financement d'un chercheur Eyes High Postdoctoral Scholar pour le Réseau, sans lequel notre recherche n'aurait pas pu être menée.

\section{SOMMAIRE}

Il est devenu de plus en plus difficile au Canada d'obtenir et de conserver l'acceptation du public pour des projets énergétiques. Des niveaux accrus de protestations, combinés avec la couverture par les médias traditionnels et sociaux de l'opposition, s'allient pour suggérer une diminution de l'acceptation publique des projets énergétiques. Les preneurs de décisions ont répondu en conséquence et divers projets énergétiques ont été soit retardés, soit suspendus indéfiniment. Cela est vrai aussi bien pour les projets énergétiques classiques que pour les énergies renouvelables, dans de nombreuses régions à travers le pays. Plusieurs projets énergétiques proposés ont récemment dû faire face à l'opposition de divers groupes d'intervenants. Par exemple, la décision de la Commission mixte d'évaluation pour le pipeline Northern Gateway est contestée devant les tribunaux canadiens. Des groupes des Premières Nations ont émis un ultimatum au gouvernement fédéral à l'effet qu'il doit choisir entre Site C (un barrage hydroélectrique proposé) et la mise en valeur du gaz naturel liquéfié en C.-B. L'expansion rapide des projets d'énergie éolienne en Ontario a engendré de longs et coûteux appels et a fait surgir un mouvement social anti-éolien. En Nouvelle-Écosse, le développement de l'énergie marémotrice est positionné comme nouvelle option d'énergie renouvelable. L'obtention de l'approbation du public est cruciale à la lumière de la récente opposition au développement de l'énergie éolienne. Comme le suggèrent ces expériences, non seulement le processus réglementaire est-il devenu plus litigieux mais en outre un concept apparemment nouveau, celui de contrat social, a su gagner l'appui du public.

Le présent livre blanc rapporte les résultats d'une collaboration interdisciplinaire visant à identifier et à résumer la recherche actuelle concernant le contrat social et les concepts associés, en accordant une attention particulière à la compréhension de ses incidences sur l'acceptation par le public des projets énergétiques au Canada et des processus réglementaires afférents. En particulier, cette recherche abordait les questions suivantes:

1. Quelle est l'historique et la portée du terme "contrat social ", tant dans le cas du développement de projets énergétiques que dans un contexte plus général ? Quels sont les points forts et les limites de ce concept? Comment contribue-t-il ou nuit-il à la politique énergétique, aux débats réglementaires et à la prise de décisions?

2. Quelles sont les similarités et les différences entre la notion de contrat social et les concepts établis et d'autres concepts ou cadres?

3. Du point de vue de l'acceptation publique des projets énergétiques, le système de réglementation canadien est-il dysfonctionnel ? De quel point de vue ? Quelles options pourrait-on envisager?

4. Quels sont les obstacles et les instruments d'habilitation (légaux, sociaux ou autres) relativement à l'obtention d'un permis dans le processus réglementaire?

5. Quel rôle le contrat social joue-t-il dans un contexte global? Quelle est la validité du concept de contrat social ? Un contrat social peut-il vraiment freiner un projet ou déterminer le résultat d'une élection ? Est-ce qu'il suscite un véritable dialogue à propos d'un projet ? Lorsque l'opposition à des projets mène à l'arrestation de personnes qui enfreignent une injonction ou à des affrontements violents, quel rôle le contrat social peut-il jouer pour favoriser une approche différente? 
En plus d'offrir un aperçu d'ensemble des concepts d'acceptation publique et de contrat social et de leurs applications au Canada, le livre blanc arrive à certaines conclusions (section 5) et présente des recommandations (section 6) pour améliorer les systèmes de réglementation canadiens et pour rehausser la confiance du public envers les divers organismes de réglementation du secteur de l'énergie au Canada. Par exemple, au moment où le gouvernement fédéral lance son programme en vue d'amender le processus réglementaire, la recherche présentée ici peut informer la meilleure manière dont le gouvernement peut s'acquitter de son mandat de réforme tout en conciliant les enjeux économiques, environnementaux, politiques, sociaux et relatifs à la sécurité pertinents pour les régulateurs, le fédéral et les gouvernements provinciaux, l'industrie, les Premières Nations les groupes environnementaux et le grand public.

L'attrait du terme " contrat social » provient de l'inclusivité et de l'équitabilité qu'il semble suggérer. Toutefois, la pression populaire à l'appui d'un droit de parole accru et de plus d'intervention réglementaire et judiciaire, découlant d'un sentiment de mécontentement et de désenchantement, n'est pas un phénomène nouveau : le contexte historique et les leçons qui en ont été tirées sont essentiels pour évaluer l'idée et situer le débat dans un cadre pertinent.

Le concept de "contrat social " implique un niveau additionnel de "réglementation ", quoique sans forme définie. Une leçon centrale de l'expérience du vingtième siècle est que la réglementation a un coût et qu'un excès de réglementation et d'intervention peut entraîner la paralysie et un "échec des pouvoirs publics». Cela sous-entend qu'on devrait recourir à la réglementation lorsqu'elle est nécessaire et qu'on devrait la mettre en application de manière judicieuse. L'une des conclusions du présent rapport est qu'on peut rehausser la confiance du public en rationalisant les instruments réglementaires existants afin de réduire la perception courante voulant que les décisions soient parfois motivées politiquement, ainsi qu'en s'assurant que les décisions soient prises aux bons paliers de gouvernement.

L'institutionnalisation du contrat social comporte également des risques identifiables. II est susceptible d'augmenter les incitatifs à un « comportement de recherche de rentes". La menace d'un veto, ou même d'une obstruction, confère au groupe concerné un avantage qui peut mener à l'extraction de rentes qui sont hors de proportion avec les impacts. Cela fait également augmenter l'incertitude réglementaire et politique associée à un projet donné, décourageant l'investissement ou exigeant des rendements plus élevés que ceux qui sont justifiés par le risque inhérent à l'entreprise proposée.

On doit analyser plus en profondeur le terme « contrat social » et son utilisation doit s'entourer de précautions. Ce concept tire son origine du " permis social d'exploitation » issu du secteur minier. Le concept ayant migré au secteur de l'énergie, sa portée semble s'être élargie, de sorte que sa signification est devenue incertaine, mal définie et déroutante. D'autres termes, tels que " acceptation », " soutien » ou " confiance du public », pourraient être plus appropriés dans le domaine énergétique. Les régulateurs, les décideurs et les politiciens devraient s'abstenir d'utiliser ces termes sans une compréhension claire de leurs implications.

Nos recommandations précises incluent ce qui suit:

1. Coordination des gouvernements. Une plus grande coordination des processus réglementaires entre le fédéral et les gouvernements provinciaux est requise et devrait avoir comme objectif d'accroître les résultats bénéfiques pour tous les intervenants visés (section 6.1).

2. Participation des intervenants. Un système cohérent, transparent et rigoureux pour identifier et rejoindre les intervenants est essentiel pour l'efficience et l'efficacité réglementaires (section 6.2). 
3. Le contrat social en tant que concept. Lorsqu'il s'agit de développement énergétique, le terme " contrat social » doit être analysé plus en profondeur et on doit faire preuve de précautions si on choisit de l'utiliser (section 6.3).

4. Premières Nations. Le fédéral et les gouvernements provinciaux devraient accepter la responsabilité de ce devoir de consultation et s'assurer de s'en acquitter d'une manière complète, tel que déterminé par le droit national et le droit international (section 6.4).

5. Modifications à la Loi sur l'ONÉ. Un examen indépendant des modifications à la Loi sur l'ONÉ concernant le délai de consultation et la liste de ceux qui peuvent être consultés devrait être effectué pour s'assurer que l'ONÉ soit sans contrainte dans sa capacité de réglementer adéquatement et jouisse de la confiance du public dans son mandat et ses décisions (section 6.5).

6. Faire un usage élargi de l'information obtenue au cours des processus d'évaluation. Les organismes de réglementation de l'énergie devraient envisager des mécanismes pour rapporter les problèmes récurrents qui dépassent la portée de leur mandat (section 6.6).

7. Conformité après l'approbation du projet. II est nécessaire de disposer d'informations accessibles au public, à jour et pertinentes relativement à la conformité et au statut postapprobation des projets. Les données devraient être placées sur un portail gouvernemental afin d'en rehausser l'accessibilité pour les intervenants (section 6.7).

8. Contre-interrogatoire dans les audiences réglementaires. La portée des contreinterrogatoires permis, ainsi que de l'ensemble de la procédure réglementaire, doit être proportionnelle à l'importance des impacts de la décision finale (section 6.8). 


\section{INTRODUCTION}

Few would argue that there is increased public interest in energy projects in Canada. What is open for debate is whether this increased public interest is associated with lower public acceptance $^{1}$ of the energy projects in question, and decreased trust of the regulator and the regulatory processes governing approval or denial of projects. Certainly, reports of project protests, ${ }^{2}$ court challenges of regulatory decisions, ${ }^{3}$ increased use of terms such as "social licence" and political pronouncements on the value (or lack thereof) of energy projects, all give the impression that there is a lack of public acceptance, and that this lack implies something may be broken with regard to Canada's regulatory system. Moreover, statements by Canadian politicians suggesting Canadians themselves do not trust the regulatory process underscore the importance of examining this topic. ${ }^{4}$

The goal of this white paper is to address the question: "When it comes to public acceptance of energy projects, is Canada's regulatory system broken?" This is not an easy or simple question to answer, as we must first attempt to define both what is meant by public acceptance and how it is measured, as well as to define the criteria for assessing "brokenness" of the regulatory system. We offer three alternative arguments on the state of the regulatory process - broken, not broken, and should be improved - to explore all sides of the issue. The objective is not to make a definitive statement on the state of Canada's regulatory system, but to explore the recent trends in energy project development and regulation, and where public policy can be improved.

The publication of this paper is especially timely as the new federal government has committed to modernizing the regulatory process, notably pipeline review processes at the National Energy Board (NEB) and environmental assessment processes for natural resource projects. The Minister of Natural Resources' 2015 mandate letter stipulates that the minister shall work with other relevant ministers on Canada's environmental assessment processes to "regain public trust and introduce new, fair processes" with particular regard for "robust oversight" and "decisions [that] are based on science, facts and evidence," ensuring citizen, indigenous group and expert participation, and reducing environmental impacts [123]. The minister's mandate with respect to the NEB is "to ensure that [the NEB's] composition reflects regional views and has sufficient expertise in fields such as environmental science, community development and indigenous traditional knowledge" [123].

\footnotetext{
Other terms commonly used include "social licence," "social acceptance" and "acceptabilité sociale." In this paper, we will use the various terms interchangeably. We recognize that there may be some nuance and differences among the terms, but do not ourselves have a preferred term. Moreover, we also note that at a very high level, the various terms are essentially synonymous.

2 Examples of public protests include pipelines in B.C., wind farms in Ontario, hydraulic fracturing in New Brunswick, and the Site C hydroelectric dam in B.C. See [57] CTV News, "Thousands Protest Northern Gateway Pipeline," Oct. 22, 2012; [11] I. Bailey, "Protesters Rally Against Trans Mountain Pipeline, but Drilling Continues," Globe and Mail, Nov. 24, 2014; [47] CBC News, "Wind Turbine Protest to Block Major Ontario Highway, Oct. 17, 2013; [46] CBC News, "RCMP, Protesters Withdraw After Shale Gas Clash in Rexton,” Oct. 17, 2013; [74] F. Dinshaw, "David Suzuki Rescues Capsized Canoers at Site C Dam Protest," National Observer, July 12, 2015. other regulators have been subject to court challenges, including the Alberta Energy Regulator on the oil sands ([98] Fort McKay First Nation v. Alberta Energy Regulator, 2013 ABCA 355) and Ontario's Environment Review Tribunal over a wind farm approval ([192] P. Morden, "Lambton County Wind Farm Approval Appealed," Sarnia Observer, April 3, 2015).

4 For example, the recent government announcement on "restoring trust" in the government's assessments. See [181] S. McCarthy, "Ottawa adds Additional Steps to Pipeline Reviews," Globe and Mail, Jan. 27, 2016.
} 
While the government is reviewing environmental assessments and the NEB, it has announced that five principles will underpin its decision-making on pipelines [124]:

- No project review will need to start from square one - it will continue under the current legislative framework;

- Decisions will be evidence-based, including science and traditional indigenous knowledge;

- Affected communities and the public will be consulted;

- Indigenous people will also be consulted and accommodated where warranted; and

- GHG emissions associated directly with the project as well as upstream will be assessed.

This white paper is of direct relevance to the above-noted federal regulatory reviews. Specifically, the paper provides a detailed analysis of the literatures addressing public confidence in the regulatory processes, along with the specificities of Indigenous rights in the energy regulatory system, and concrete recommendations for changes to the regulatory framework to strengthen public faith in the system. The rest of the paper proceeds as follows. We begin with an overview of the role of regulatory bodies and regulation in Canada; readers more familiar with regulatory processes and levels of jurisdiction may choose to skip this section. The next section covers the history, definitions and use of the terms "social licence," "social acceptance" and "public acceptance," including attempts to measure the terms, how Aboriginal-Canadian rights differ from the idea of social licence, and examples in the context of energy projects. We then offer three cases on the state of Canada's regulatory process - that it is broken (section 3), not broken (section 4.2), and not broken but can be improved (section 4.3). These cases are followed by conclusions (section 5 ) and policy recommendations (section 6).

\section{REGULATION AND THE ROLE OF REGULATORY BODIES}

Any analysis of regulation and the role of regulatory bodies in the energy sector must begin with an appreciation of the policy context within which regulators function. Broadly speaking, energy policy addresses three key imperatives: economics, environment and security $[107,111,251]$. The first relates to markets, and deals with the economic underpinnings of energy markets, ensuring they work efficiently and competitively, and that Canadian energy producers have access to international markets for export. The second deals with the environmental impact of energy exploration, production, transmission and consumption, and comprises such matters as species at risk, human health and safety, climate change, and land and water use. The third policy imperative is energy security, and includes security for Canadian consumers and the economy (affordability, reliability, price stability and security of supply) as well as security of critical energy infrastructure (the physical and cyber-security of pipelines, nuclear facilities, electricity transmission infrastructure, etc.). Clearly, balancing among market, environmental and security imperatives in a way that garners social acceptance and support (a.k.a., social licence) is a tall order. 
In Canada, this policy complexity is further heightened by the division of energy powers in the constitution. Canada has one of the most divided and decentralized constitutional arrangements for energy among Western industrialized countries [77]. When it comes to energy markets, the provinces are dominant players. They have constitutional jurisdiction over non-renewable natural resources, including exploration, development, management, royalties and intra-provincial energy trade and commerce. They also have jurisdiction over the generation, production, transmission and sales of electricity within their boundaries (nuclear is an exception, as discussed below). The federal government's powers most closely related to energy markets derive from its jurisdiction over interprovincial and international trade and commerce (including foreign investment), international treaty-making, taxation, fisheries, and energy development offshore and on frontier lands. The federal government has truncated or devolved a number of its powers in these areas. With respect to offshore and frontier lands, it has negotiated agreements with provincial and territorial governments to delegate or co-manage regulatory authority and royalties. And with the negotiation of the Canada-U.S. Free Trade Agreement, it in effect used federal treaty-making powers to liberalize international energy trade, thereby reducing its control over international energy flows.

Ottawa also intervenes in the energy sector via federal spending power and equalization. With respect to the former, recent examples include federal loan guarantees for the Muskrat Falls hydroelectric development in Newfoundland and Labrador, and federal investments in carbon capture and storage projects in Alberta and Saskatchewan. With respect to the latter, the federal government decides whether or not (or under what circumstances and how) energy royalties or other provincial revenues in the energy sector are included in equalization formulas. The federal government also plays a strong role when it comes to the development of energy resources on or crossing Aboriginal lands, given its jurisdiction over reserves and in instances where it negotiates land claims or other agreements (provinces, of course, can also be key actors in these arrangements).

The environmental imperative of energy policy arguably generates the greatest level of involvement of both provincial and federal governments in the energy sphere. Provinces have jurisdiction over the conservation of energy resources within their boundaries as well as intra-provincial environmental impacts of energy. The federal government has jurisdiction over trans-boundary environmental impacts, as well as fisheries, navigation and shipping, agriculture, criminal law, and the power to legislate for peace, order and good government. Any single energy project is very likely, therefore, to trigger federal and provincial governments' involvement through their respective environmental powers.

When it comes to energy security, the federal government is a dominant player through its role in critical energy infrastructure protection and in nuclear safety via the Canadian Nuclear Safety Commission. The federal government has also promoted nuclear industry development through the Crown corporation, Atomic Energy of Canada Limited, portions of which have been privatized in recent years.

In pursuing the complexity of policy aims in the energy sphere, both federal and provincial governments employ the policy instrument of regulation. Regulation, as a policy tool, refers to "rules of behaviour backed up by sanctions of the state" [78]. It is expressed in a variety 
of forms - constitutions, statutes, delegated legislation, guidelines, standards, codes, etc. — to which varying degrees of state sanction are attached [77]. ${ }^{5}$

In terms of implementation, governments delegate regulation and regulatory development to agencies such as the National Energy Board, the Canadian Environmental Assessment Agency, the Canadian Nuclear Safety Commission, the Ontario Energy Board and the Alberta Energy Regulator.

Legislatures set the overall policy frameworks within which regulators function via enabling legislation (e.g., the National Energy Board Act). ${ }^{6}$ Statutes stipulate the broad policy objectives to be pursued by the regulator when it comes to developing regulatory frameworks and making decisions about individual energy projects. This institutional arrangement aims to depoliticize decision-making on individual projects. Rather than project approvals playing out in the political arena, regulatory agencies undertake expert evidence-based analyses in a quasi-judicial setting. They are generally directed by their enabling legislation to regulate in the public interest, which is defined in statute as pursuing a variety of policy imperatives (e.g., economic development, environmental protection, affordability, security, etc.).

Regulators develop detailed regulations to fulfil their mandate in operational terms, translating broad policy objectives such as "pursuing the public interest," "economic development," "environmental protection," and the like into concrete rules, guidelines and standards to which industry proponents and individual projects must adhere. In addition to these substantive regulatory measures, regulators also develop procedural frameworks for how they will make their decisions. These include whether or under what circumstances a public hearing will be held, along with whom, and how various stakeholders can participate in the decision-making process. The resulting framework of substantive and procedural regulations is revised and modified on an ongoing basis in light of experience, available budgetary resources, new scientific evidence and industry practices, stakeholder expectations, etc. As such, the regulatory framework is forever a work in progress. Moreover, regulatory bodies in different jurisdictions may interpret similar policy objectives in varying ways owing to their particular institutional, economic, environmental, geological, political and social contexts.

What is common to their activities, however, is that they either approve or reject proposed projects in light of the regulatory framework governing their decision-making in substantive and procedural terms. If a regulator approves a project, a licence is awarded to the project proponent, usually with a variety of conditions that a company must adhere to when it comes to project development, operation and abandonment. Once a project is underway, regulators monitor project activities for compliance, and can enforce regulations with sanctions (fines, suspension of licence, etc.) in cases of non-compliance.

\footnotetext{
As noted in the concluding section of this paper, governments have also engaged in deregulation, notably to liberalize energy markets. In Canada, this got underway in the 1980s in oil and gas, in the 1990s in electricity, and included price deregulation, trade liberalization and introducing greater competition into energy markets. See [227] A. Plourde, "The Changing Nature of National and Continental Energy Markets," Canadian Energy Policy and the Struggle for Sustainable Development, edited by G. Bruce Doern. 
When a project proponent or other stakeholder disagrees with a regulatory body's decision, there are various mechanisms of appeal. These include appeals directly to the government (usually to a minister or cabinet, which can overturn a decision) and appeals to the courts (different courts depending on the nature of the appeal).

At the federal level, the National Energy Board was created in 1959 following a recommendation of the 1957 Royal Commission on Energy (the Borden Commission), which analyzed the interplay between domestic and international energy markets [183]. The 1950s were a transformative period for the Canadian energy sector as it began to produce oil and gas far in excess of requirements in the province of production. Prior to the NEB's creation, in order to ship oil and gas beyond provincial boundaries, pipeline companies required parliamentary approval to become incorporated, which opened the door to political interference in market decision-making.

At the time, not unlike today, there were multiple major pipeline proposals on the table to carry Canadian energy to domestic and export (at the time, only American) markets. Political debates in the 1950s turned on which markets Canadian oil and gas should serve (domestic and/or American), which pipeline routes should be used to carry it there, and whether pipeline companies should be wholly Canadian-owned and controlled. Political debate was fierce and contentious, to the point that the St. Laurent Liberal government lost power to the Diefenbaker Progressive Conservatives in the 1957 general election, in part because of its position on pipelines. Almost immediately upon gaining power, the Diefenbaker government struck a royal commission to undertake an independent study of a host of energy policy issues.

The Borden Commission's mandate included consideration of which regulatory framework should govern pipeline approvals and the setting of pipeline tolls, rates and tariffs for shippers. The commission recommended that the government create an independent regulatory commission to take decisions on interprovincial and international energy projects (pipeline construction, tolls, tariffs and rates).

The National Energy Board Act, passed into law in 1959, confers authority on the NEB to regulate offshore areas and frontier lands not covered by federal-provincial agreements; the construction, operation and abandonment of interprovincial and international energy infrastructure (oil and gas pipelines and, where designated, electric power lines); tolls and tariffs for oil and gas pipelines under its jurisdiction; international exports and imports of natural gas; and international exports of oil, natural gas liquids, refined petroleum products and electricity. This mandate circumscribes the geographical and functional activities over which the NEB has regulatory authority. The act also circumscribes the extent of the Board's authority. In the case of pipeline project approvals, for example, the original act conferred on the Board the authority to reject pipeline proposals, but given the potential national impact of constructing new pipelines, final authority to approve projects rested with the government [129]. Similarly, the NEB Act does not mandate the Board to address climate change or reduce greenhouse gas emissions, thereby leaving these issues in the hands of policy-makers (the NEB examines the emissions generated from the construction and operation of a pipeline, but it does not have authority to regulate GHG emissions 
produced when fossil fuels are extracted, produced or consumed ${ }^{7}$ ) [77]. Nonetheless, there is no question that the NEB's original energy-sector-based regulatory role has been joined over time by consideration of environmental and safety concerns, some in conjunction with other legislation and regulatory agencies - in environment, for example, with the Canadian Environmental Assessment Act and the Canadian Environmental Assessment Agency [77]. Most recently, as noted above, while the federal government is reviewing the environmental assessment process and the NEB, it has announced interim changes for major energy projects, in particular that the government will include an assessment of upstream emissions from the production of fossil fuels in decisions. ${ }^{8}$ The extent to which this change will affect the NEB's mandate and process is yet to be determined.

The legislative frameworks governing the mandates and activities of energy regulators like the NEB are, of course, not static. Governments, through the legislative process, can and do amend regulators' enabling legislation when political, economic, geological, social or other circumstances change. In the NEB's case, for example, the federal government brought a bill before Parliament to amend the NEB Act in 2012, in the context of a broader process of legislative change aimed at reducing regulatory burden on investors in Canada's natural resource sector. Under the banner of Responsible Resource Development (unveiled in Budget 2012), the government noted that "those who wish to invest in our resources have been facing an increasingly complicated web of rules and bureaucratic reviews that have grown over time, adding costs and delays that can deter investors and undermine the economic viability of major projects."

Amendments to the NEB Act undertaken in this legislative reform process included:

- The requirement that applications for Certificates of Public Convenience and Necessity (CPCN) that the NEB plans to reject come to cabinet for review and possible approval (i.e., final decision-making power to both approve or deny a CPCN now rests with the government);

- The establishment of a fixed timeline between the date a CPCN or exemption order application is complete and the submission of a recommendation by the Board to the government (15 months, although extensions are possible); and

- Enhanced powers for the Chair of the NEB to intervene in an application process if it appears the new timelines are not likely to be met.

While the government's stated aim with these amendments was to support expeditious and timely project reviews, some have criticized the changes for reducing the comprehensiveness of regulatory reviews, decreasing the opportunity for various stakeholders to participate in NEB decision-making processes, and for leaving the fate of major project proposals directly in the hands of the prime minister and cabinet.

See [279] Peter Watson, "In the Eye of the Storm," Speech to the Economic Club of Canada. Canadian Energy Summit, 2014, Calgary, Alberta, Nov. 21, 2014.

8 See [124] Government of Canada, "Government of Canada Moves to Restore Trust in Environmental Assessment," January Jan. 27, 2016.

9 See [122] Government of Canada, Ministry of Finance, Jobs, Growth and Long-Term Prosperity: Economic Action Plan 2012: 88. 
To be fair, the NEB has had its hands full with unprecedented numbers of individuals, groups and other parties wanting to participate in its hearing processes, and some on grounds that go beyond the issues the NEB considers in its review processes, notably climate change. This was perhaps most vividly on display during the Joint Review Panel (JRP) process for the Northern Gateway pipeline proposal, when opponents of the project banded together to mob the mic at JRP hearings. More recently, the NEB was presented with a petition by organizations, including 350.org, Leadnow.ca and the Council of Canadians, demanding the Board include greenhouse gas emissions from the oil sands in its review of the Energy East pipeline proposal. The groups stated the petition was supported by some 100,000 Canadians, which would make it the largest petition ever submitted to the NEB.

As suggested above and throughout this paper, expectations for stakeholder involvement in regulatory processes appear to be mounting. At this stage, however, it is not always clear that regulatory processes are the appropriate channels for voicing concerns, particularly where they deal with policy matters beyond the scope of a regulator's legislative mandate (e.g., climate change). Where expectations are in-mandate, the provision in the 2015 federal budget of additional funding to the NEB for public participation in pipeline proposal reviews suggests the government recognizes that public involvement in regulatory processes is important and requires additional resources in order to be undertaken.

This discussion of the NEB points to both the place of regulators in the broader energy policy sphere, as well as the sorts of challenges regulators face when it comes to social acceptance and support (or lack thereof) for energy development. At the provincial level, virtually all provinces have established regulatory bodies in the energy sphere. Section 3.6.3 of this paper includes an examination of the mandate, roles and activities of the Ontario Energy Board for illustrative purposes.

When it comes to real or perceived public dissatisfaction with regulators, regulatory processes or regulatory decisions, a number of issues emerge as important takeaways from this discussion:

- Regulators are not policy-makers. They operate within the context of a legislatively defined mandate that lays out broad policy objectives. Regulatory agencies develop a detailed regulatory framework through which to pursue these policy objectives. Where public dissatisfaction pertains to questions of policy, regulators may be illpositioned to address them;

- Regulators are intended to be technical, expert-based bodies that make decisions based on a rational assessment of evidence, not based on political expediency. They were created in order to depoliticize decision-making with respect to individual energy projects. Nonetheless, where project proposals are contentious, regulators' actions may be perceived, rightly or wrongly, as political if they are seen to privilege one dimension of their mandate (e.g., economic development) over another (e.g., environmental protection);

- While regulators operate at arm's-length from the government of the day, they are public bodies whose authority ultimately derives from Parliament and provincial 
legislatures, and their decisions can be appealed to public authorities, be they the government of the day or the courts;

- Public expectations for greater involvement in regulatory decision-making can bear real consequences for regulators and the regulatory process, including increasing financial costs and timelines.

\section{HISTORY, DEFINITIONS AND USE OF SOCIAL LICENCE AND SOCIAL ACCEPTANCE}

"Drunks are accorded great social licence in Oaxacan villages. They may shout insults, intrude uninvited into social gatherings, and behave in other normally unacceptable ways" [68].

As reflected in the epigram, social licence is not a new concept, and in fact, has long been understood to play a vital control function in society. ${ }^{10}$ Over the past two decades, however, there have been increasing references to the concept of social licence, especially in the context of mining, hydrocarbon extraction, and other resource-intensive projects. For instance, news media mentioned the term fewer than 10 times in the years 1997 through 2002, but more than 1,000 times each in 2013 and 2014. ${ }^{11}$ Most often, the concept of social licence has been promulgated by industry executives and government officials [234]. And yet, despite the term's growing popularity, to our knowledge no comprehensive academic review of this work has been undertaken. In this section, we review and analyze existing literature, including industry publications, popular books, journal articles, and reports from industry, consultants and government. Rather than a singular concept, our review identifies and synthesizes what we term three different "varieties of social licence."

After highlighting some of the similarities and differences between these varieties, we distill one concept common to all of them: legitimacy. To the extent that the core idea animating social licence is legitimacy, it can be understood as akin to putting old wine in a new bottle. In fact, scholars have long understood that all organizations, whether governments, corporations or non-profits, must demonstrate their legitimacy, or social acceptability, if they are to survive and succeed. Conversely, as prior research has repeatedly shown, a lack of legitimacy can be a formidable, even fatal, threat to organizational success and survival.

\subsection{Varieties of Social Licence}

\subsubsection{The Pyramid Model}

The first variety of social licence we review, known as the pyramid model, was developed iteratively in a series of articles, papers and presentations by mining industry consultants

\footnotetext{
In Oaxaca, Mexico, evidence of human habitation dates to 11,000 BC.

11 We searched Factiva for mentions of "social licence" or "social licence" in North American print media, Jan. 1, 1997 to Dec. 31, 2014, inclusive.
} 
over the 14-year period from 2000 to 2013. As the inspiration for their model, proponents credit James Cooney, then an executive at Canadian gold mining company Placer Dome $[24,27,261] .{ }^{12}$ In 1996, Placer Dome had been severely criticized after a tailings dam failed at one of its mines in the Philippines, releasing toxic mud into a river and burying a village [27]. More generally, mining was ranked the worst of 24 U.S. industries in a 1996 Roper opinion poll, behind even the tobacco industry [261]. It was in this context in 1997 that Cooney reportedly characterized the industry's problems to officials with the World Bank as a matter of obtaining a "social licence to operate." Personnel from the World Bank are said to have circulated the term at a May 1997 conference on "mining and the community" that was held in Quito, Ecuador [261].

In 2002, the International Institute of Environment and Development published Breaking New Ground: Mining, Minerals and Sustainable Development. The result of a two-year process, this landmark industry report declared that the industry "has been failing to convince some of its constituents and stakeholders that it has the social licence to operate in many parts of the world" [150]. Without ever defining what it meant by social licence, the report revealed an inextricable link between the mining industry's survival and the notion of social licence. In short, this variant of social licence to operate "emerged as an industry response to opposition and a mechanism to ensure the viability of the sector" [218].

From there, the metaphor apparently stuck. For instance, in a 2003 project sponsored by Newmont Mining Corporation, Business for Social Responsibility published six case studies on social licence to operate in the mining industry, noting: "Gaining a social licence to operate simply means gaining support for the project from concerned groups, or stakeholders, over and above meeting any legal requirements" [33]. A convenience survey $(n=152)$ of mining industry participants conducted during 2005-2006 found 78 per cent of respondents were familiar with the term "social licence"; 81 per cent agreed that social licence referred to "the acceptance and belief by society, and specifically our local communities, in the value creation of our activities, such as we are allowed to access and extract mineral resources"; and 56 per cent reported their organization used the term or its underlying concepts [201].

As articulated in these accounts, social licence to operate was initially little more than a memorable turn of phrase, "a term largely invented by business, for business" [194, 234]. Based on our review, a February 2000 article in CIM Bulletin entitled "Earning a Social Licence to Operate" was the first attempt to provide the term with some conceptual substance [156]. Susan Joyce, a consultant with Calgary, Canada-based Golder Associates, and Ian Thomson, an independent consultant from Vancouver, Canada, began their article by cataloguing various social risks facing mining companies in Latin America. At the project level, these risks were argued to threaten social acceptability by posing what they termed "problems of legitimacy." To counter these legitimacy problems they proposed [156]:

12 There are some discrepancies between Thomson and Boutilier (2011) [261] and Boutilier (2014) [27]. For instance, Thomson and Boutilier (2011: 1779) described Jim Cooney as "director of international and public affairs," whereas Boutilier (2014: 263) described him as "vice president of external relations." Thomson and Boutilier indicated the World Bank conference occurred in May 1997, whereas Boutilier described it as "early 1998." Based on documents from the World Bank, we ascertained that the conference was held May 6-8, 1997, and the proceedings were published in April 1998 (see [184], G. McMahon, 1998. "Mining and the Community: Results of the Quito Conference." Quito, Ecuador: The World Bank). Of note, however, we found no mentions of "social licence" or Cooney in the proceedings. Thus, the archival record is not able to confirm this particular origin story. 
"A social licence to operate exists when a mineral exploration or mining project is seen as having the approval, the broad acceptance of society to conduct its activities ... Such acceptability must be achieved on many levels, but it must begin with, and be firmly grounded in, the social acceptance of the resource development by local communities."

Some years later, in an industry conference presentation, Thomson and Joyce expanded their definition of social licence to operate to include three normative components: legitimacy ${ }^{13}$ credibility and trust [264]. They defined legitimacy as "conforming to established norms - norms may be legal, social, cultural and both formal and informal"; credibility as "the quality of being believed - the capacity or power to elicit belief"; and trust as "willingness to be vulnerable to risk or loss through the actions of another." They further differentiated between project acceptance and approval, arguing that legitimacy was necessary for acceptance, whereas they linked credibility and trust with approval. Looking back on these developments, Robert Boutilier [27], also an industry consultant, credited Joyce and Thomson as having made two distinctive contributions. For one, they were the first to define social licence to operate in terms of legitimacy. And two, their work proposed that social licence to operate at the project level would promote reputation benefits at the corporate level..$^{14}$

Thomson and Boutilier reiterated this threefold definition of social licence to operate (i.e., legitimacy, credibility and trust) and elaborated a multilevel pyramid model, illustrated in Figure $1[261,262]$. In this model, legitimacy was conceptualized as distinguishing between projects that have their social licence to operate withheld or withdrawn and projects that are accepted. Credibility was conceptualized as distinguishing between project acceptance and approval. Finally, trust was conceptualized as distinguishing between project approval and what they initially called "co-ownership," but later labelled "psychological identification" [261]. In addition to its original proponents, the Australian Centre for Corporate Social Responsibility recently has adopted the pyramid model of social licence to operate. Notably, the centre's managing director, Leeora Black, has promoted the pyramid model as a "management framework for complex times" [24].

13 As we will discuss later, the construal of legitimacy as merely a normative concept represents an incomplete understanding relative to prior academic formulations. Rather, legitimacy has been conceptualized as multifaceted, entailing not only a normative dimension, but others as well (e.g., cognitive, socio-political). 


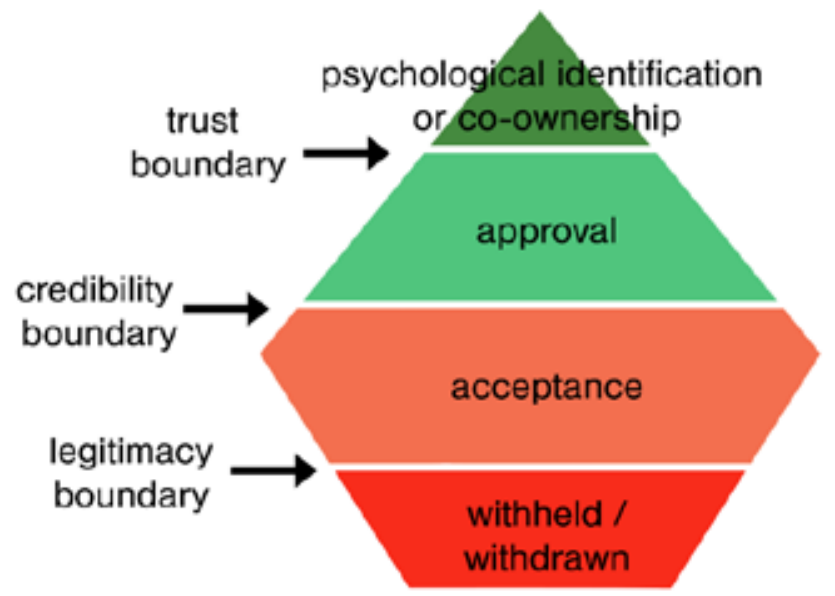

Source: Adapted from [29] R. G. Boutilier and I. Thomson, "Modelling and Measuring the Social Licence to Operate: Fruits of a Dialogue Between Theory and Practice," 2011.

In sum, the pyramid model of social licence to operate initially emerged as "a term largely invented by business, for business" [194, 234]. From there, a coterie of consultants have attempted to give the term some conceptual substance, linking it with existing social scientific concepts - legitimacy, credibility and trust [24, 28, 156, 261, 262, 264]. Most recently, Black has defined social licence to operate as a "level of acceptance or approval continually granted to an organization's operations or project by local community and other stakeholders" [24]. At its core, the pyramid model considers social licence to operate as "a judgment about the legitimacy of your company or operations" [24].

The pyramid model posits four levels of social licence to operate, ranging from withdrawal to acceptance to approval to psychological identification. Further, the level of social licence to operate with regard to a company or project is said to vary across time or between stakeholder groups in response to actions by the company or its stakeholders. For the most part, this work has been published in the form of industry presentations, industry conference papers, a handbook chapter and industry trade journal articles. To our knowledge, this particular variant of social licence to operate has not been subjected to any meaningful peer review. As one consequence, this work is little cited, with a total of 257 citations across seven publications dating back some 15 years (see Table 1). 
TABLE 1 SCHOLARLY IMPACT OF THE PYRAMID MODEL

\begin{tabular}{|l|l|l|l|}
\hline Authors & Date & Format & \multicolumn{1}{|c|}{ Citations } \\
\hline [156] Joyce \& Thomson & 2000 & Industry article & 80 \\
\hline [264] Thomson \& Joyce & 2008 & Industry presentation & 12 \\
\hline [261] Thomson \& Boutilier & 2011 & Mining handbook chapter & $\mathbf{9 8}$ \\
\hline [29] Boutilier \& Thomson & 2011 & Working paper & $\mathbf{3 3}$ \\
\hline [262] Thomson, Boutilier \& Black & 2011 & Industry presentation & 0 \\
\hline [28] Boutilier, Black \& Thomson & 2012 & Industry paper & 24 \\
\hline [24] Black & 2013 & Electronic book \\
\hline Totals & & & 10 \\
\hline
\end{tabular}

Note: Citation counts from Google Scholar, May 1, 2016.

\subsubsection{The Three-Strand Model}

A second variety of social licence, that we refer to as the three-strand model, was developed in a series of interrelated publications in 2003 and 2004 [131, 132, 157, 265]. Whereas the pyramid model started with the term social licence to operate and worked backwards, Neil Gunningham and colleagues started with a series of research questions and worked forward: "Why has corporate environmental performance improved over time? Despite this improvement, why are some firms better environmental performers than others? How, and to what extent, can corporations be motivated to go beyond compliance with existing environmental regulations?" [131: 2].

To answer these questions, these scholars conducted an in-depth study of the environmental performance of a sample of 14 pulp mills located in the United States, Canada, Australia and New Zealand. The comparative nature of their research design enabled them to study the extent to which different regulatory methods provide greater incentives for (or impediments to) corporate decisions to go beyond compliance with regulatory requirements; how pressure from community or environmental groups was facilitated or inhibited by different regulatory regimes; and the role of corporate factors, such as the attitudes and commitments of the company executives, in shaping environmental performance. Data sources included lengthy on-site, semi-structured interviews with environmental managers at each sampled facility and in most cases with mill managers as well, and a variety of quantitative and qualitative environmental performance indicators.

Based on their research, the authors proposed that companies in "closely watched industries" depend upon a multi-stranded licence to operate. One strand is the legal licence: the regulatory permits and statutory obligations embodying the demands of regulators, legislators and judges. A second strand is the social licence: the demands of local and national environmental activists, local community groups, and, on occasion, the general public. The third strand is the economic licence: the demands of top management, lenders and investors for cost-cutting and profitability. In addition to their direct effects, these different strands were proposed to have interactive effects. For example, environmental groups may seek to enforce social licence directly (e.g., through shaming and adverse publicity), but also may attempt to influence the terms of the economic licence (e.g., generating consumer boycotts of environmentally damaging products), and of the legal licence (e.g., through citizen suits or political pressure for regulatory initiatives). 
More recently, John Morrison, executive director of the Institute for Human Rights and Business, has proposed a variant of the three-strand model (see Figure 2) [194]. Morrison retains the legal licence and social licence, but refers to political licence rather than economic licence. Although this may seem like a significant difference, it may be of little consequence. The only time the political licence is not driven by economic considerations, is if "you live in North Korea" [194: 22].

\section{FIGURE 2 THE THREE-STRAND MODEL}

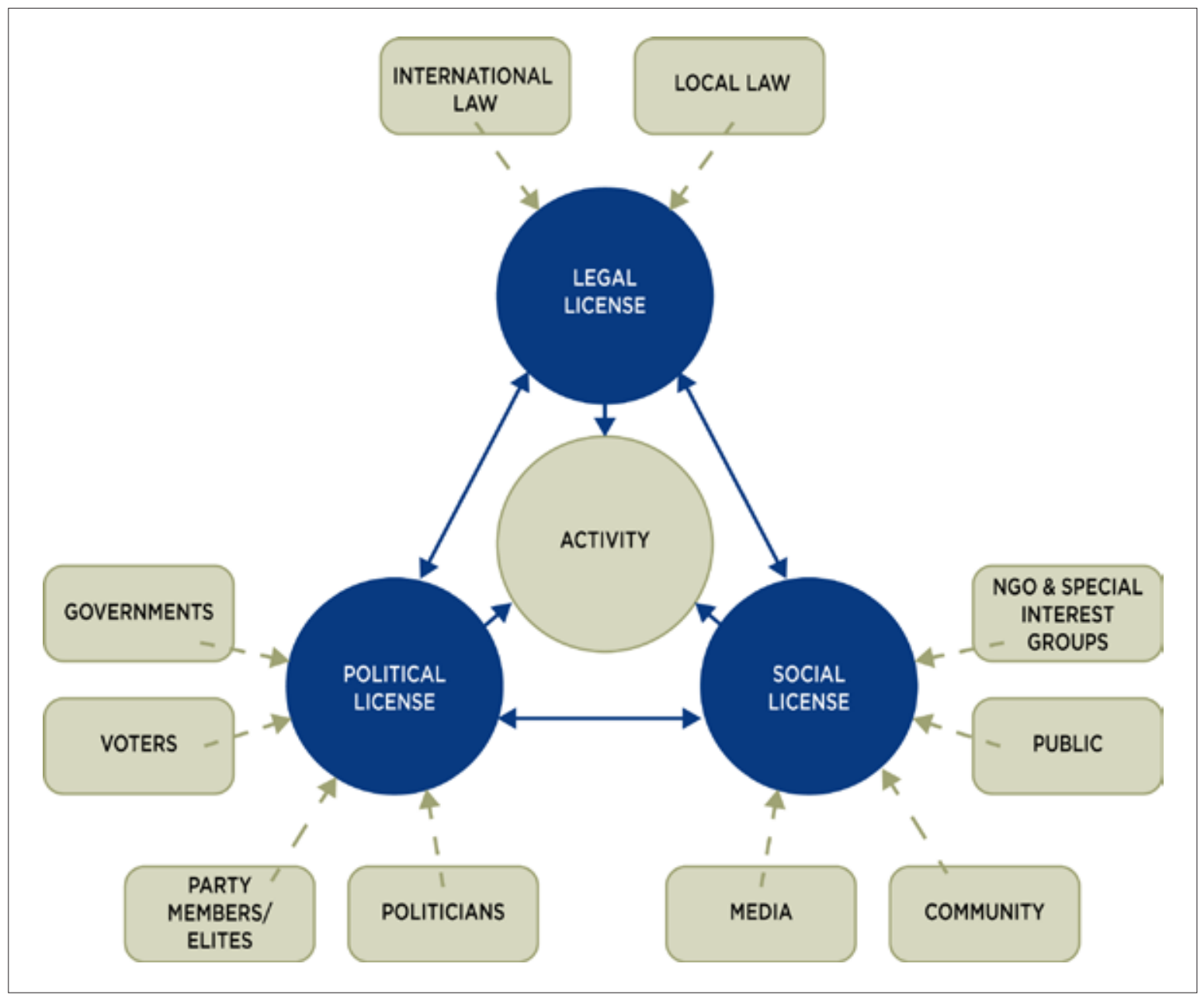

Source: Adapted from Figure 2.2 in [194] J. Morrison, The Social Licence: How to Keep Your Organization Legitimate, (London: Palgrave Macmillan, 2014), 21.

Over the past decade, the original three-strand model [131, 132, 157, 265] has spawned a variety of follow-on work. One particularly interesting paper by Gary Lynch-Wood and David Williamson focused on how social licence can affect the environmental performance of small and medium enterprises (SMEs) [177]. In particular, this work examined whether social licence concerns are sufficient to entice smaller firms to go beyond regulatory compliance in their environmental performance. Lynch-Wood and Williamson present five factors that make up the social licence: environmental impact of the firm's products and processes; customer power; customer interest; corporate/brand visibility; and community pressure. They argued that at least two of these factors must be salient to an SME for it to go beyond compliance in its environmental performance. They provide examples where larger, highly visible global organizations have gone beyond compliance, and concluded that 
for most SMEs, none of these five factors is significant enough to encourage going beyond compliance, and therefore, regulators cannot depend on social licence considerations to either incentivize or sanction these firms.

Thornton, Gunningham and Kagan corroborated this conclusion in two papers [266, 267]. In these papers, the authors returned to the same interview techniques they used in their original pulp and paper mill study, but this time studied the U.S. trucking sector. The authors characterize this industry as being representative of a perfectly competitive one, with many small-sized firms operating with tight profit margins. In these works, social licence is defined as pressure from communities, advocacy groups, employees and the news media. In a finding very similar to Lynch-Wood and Williamson, they concluded that, due primarily to low social visibility, environmental decisions in small trucking firms are driven almost entirely by the economic licence, and that social licence pressures faced by these firms are very weak.

Howard-Grenville, Nash and Coglianese add to this discussion by showing that the beyondcompliance activities organizations undertake are not solely driven by external factors, such as social licence concerns [145]. Specifically, the authors examined five internal factors: managerial incentives; organizational culture; organizational identity; organizational self-monitoring; and personal affiliations and commitments. They examined the impact of these factors in interviews with 10 companies, five of which were participating in the U.S. Environmental Protection Agency's voluntary National Environmental Performance Track program. The authors found that firms in the two groups differed in three of the factors - company identity, self-monitoring and managerial incentives. They concluded that, while external regulatory, social and economic factors are certainly significant in a company's willingness to go beyond compliance, it is also independently affected by internal factors as well.

In sum, the three-strand model of social licence emerged as an explanation for observed differences in corporate environmental performance [131, 132, 157, 264]. Subsequent work has added to our understanding of how specific stakeholder groups can influence social licence [177, 266, 267], and has expanded the model to account for internal organizationallevel factors [145]. At its core, the three-strand model posits that organizations depend upon a multi-stranded licence to operate, and that these factors both independently and interactively shape corporate environmental performance. The three-strand model has been developed exclusively by academics who have published their research in scholarly books and peer-reviewed articles. As one consequence, the eight publications have been cited some 1,486 times during the past 13 years (see Table 2). 
TABLE 2 SCHOLARLY IMPACT OF THE THREE-STRAND MODEL

\begin{tabular}{|c|c|c|c|}
\hline Authors & Date & Format & Citations \\
\hline [131] Gunningham, Kagan \& Thornton & 2003 & Academic book & 372 \\
\hline [157] Kagan, Gunningham \& Thornton & 2003 & Peer-reviewed article & 305 \\
\hline [265] Thornton, Kagan \& Gunningham & 2003 & Peer-reviewed article & 79 \\
\hline [132] Gunningham, Kagan \& Thornton & 2004 & Peer-reviewed article & 495 \\
\hline [177] Lynch-Wood \& Williamson & 2007 & Peer-reviewed article & 59 \\
\hline [145] Howard-Grenville, Nash \& Coglianese & 2008 & Peer-reviewed article & 107 \\
\hline [266] Thornton, Gunningham \& Kagan & 2008 & Peer-reviewed article & 27 \\
\hline [267] Thornton, Gunningham \& Kagan & 2009 & Peer-reviewed article & 42 \\
\hline \multicolumn{3}{|l|}{ Totals } & 1,486 \\
\hline
\end{tabular}

Note: Citation counts from Google Scholar, May 1, 2016.

\subsubsection{The Triangle Model}

The two literature streams already reviewed explicitly discuss social licence, one in the context of the mining industry, and the other in closely watched industries such as pulp and paper mills. Our third variant developed the concept of social acceptance in the context of the renewable energy sector. Namely, in the 1970s and 1980s, amid the first concerted efforts to develop renewable energy policies, policy-makers, energy companies, investors and academics assumed implementation would be unproblematic due to consistently high polling support for wind, solar, and other renewable technologies. Academic research conceived of the social acceptance issue more in the sense of building confidence, familiarity and trust in environmentally friendly but unproven technologies. This was considered to be required to generate the support from policy-makers to put in place the financial and regulatory incentives that were necessary to overcome entrenched interests and path dependency of conventional fossil fuel energy systems.

Initially, the problem of social acceptance was largely neglected, in part because public opinion surveys indicated very high levels of support for renewable energy options. However, Carlman has shown that public opinion surveys did not necessarily translate into "public, political and regulatory acceptance" of renewables, such as wind power [41]. Her analysis showed these "non-technical factors" were more consequential to social acceptance than public opinions.

More recently, Wüstenhagen et al. summarized this work as highlighting "a powerful barrier to the achievement of renewable energy targets: social acceptance" [291]. They distinguished three dimensions (see Figure 3). Socio-political acceptance refers to the broadest, most general level of social acceptance, of both policies and technologies, by the public, key stakeholders and policymakers. Community acceptance refers "to the specific acceptance of siting decisions and renewable energy projects by local stakeholders, particularly local residents and local authorities" [291: 2685]. Additionally, community acceptance implicates "a time dimension" in the sense that the pattern of local acceptance is apt to vary considerably before, during and after the implementation of a particular project. Market acceptance refers to the process of market adoption of an innovation. In particular, energy projects are embedded in complex multi-sided infrastructures, in which consumers, investors and producers are all involved. 
Wüstenhagen et al. describe this form of social acceptance of renewables as "sociopolitical" to distinguish it from the responses of host communities to wind farms or other renewables ("community acceptance") and from the "market acceptance" of consumers as measured through willingness-to-pay models [291]. This three-pronged distinction continues to provide a useful point of departure for this literature. Public opinion polls tend to show that while the general public remains favourable to the idea of wind, solar, biomass, wave, geothermal and other renewable energy technologies ("socio-political acceptance"), host communities are not as supportive ("community acceptance" [72, 73, 223]). Wind energy projects are the most studied examples [70, 93, 272, 288]. This literature is clear that there is an important distinction between support for wind energy in the abstract and a specific local wind project. This distinction is corroborated by several studies on the social acceptability of wind energy projects in the province of Quebec, which show that proposed wind energy projects in the Gaspé region of Quebec are extremely territorialized due to local concerns about alteration of the landscape far outweighing all other variables in the decision process $[100,101,102,109] .{ }^{15}$ There is no reason to expect that general public support for wind energy will automatically translate into local support for specific wind energy projects. This concept is sometimes referred to as the "social gap" in the literature to signify the gap between public support for the general goal of more wind energy but a lack of on-the-ground support $[19,20]$.

\section{FIGURE 3 THE TRIANGLE MODEL}

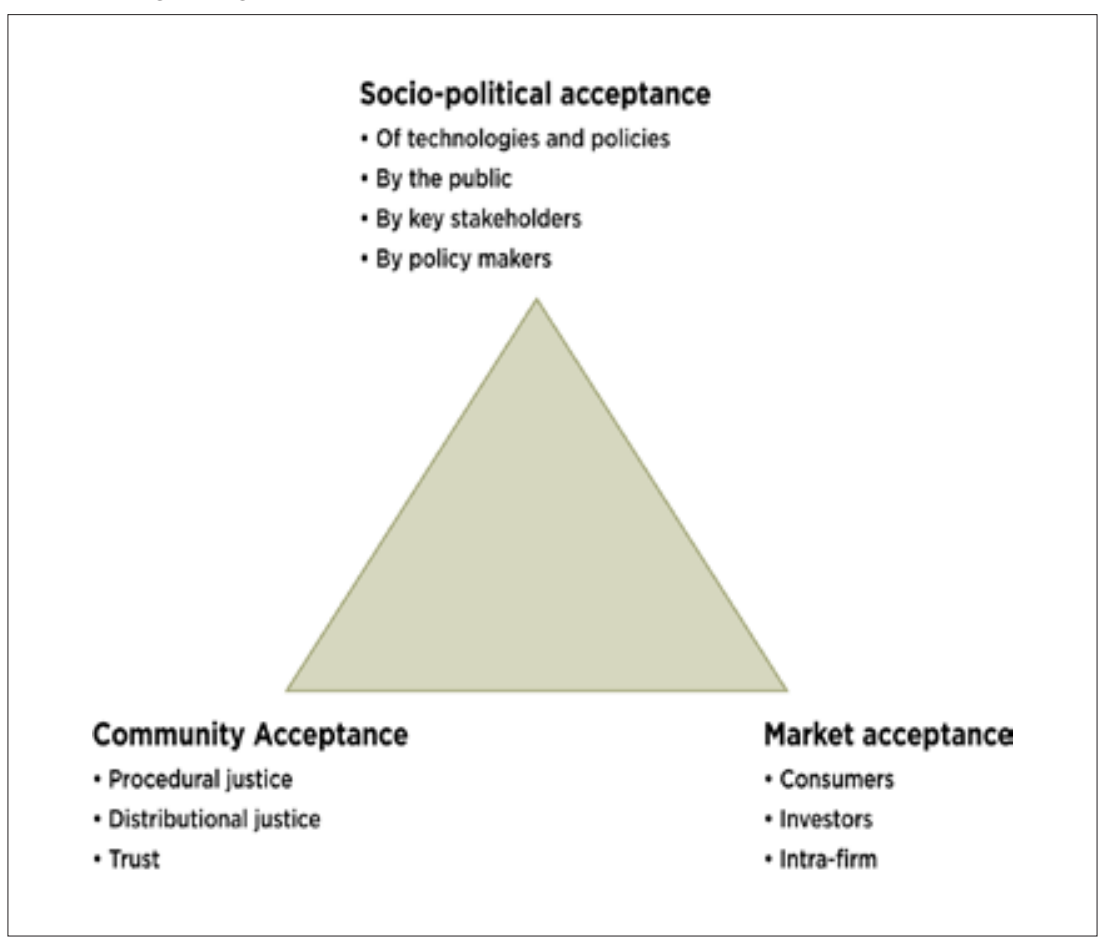

Source: Adapted from [291] R. Wustenhagen, M. Wolsink, and M. J. Burer, "Social Acceptance of Renewable Energy Innovation: An Introduction to the Concept," Energy Policy 35, 2007, 2683-2691.

The reaction to the social gap from policy-makers, renewable energy developers and other experts is a tendency to see recalcitrant local publics who oppose renewable energy

15 There is a significant body of French literature on the topic of l'acceptabilité sociale from a handful of Quebec scholars, which was beyond our resources to examine in great detail. Significant pieces on the topic of wind power in Quebec are referenced above. 
projects as ignorant and uninformed. The not-in-my-backyard (NIMBY) concept describes the situation in which an individual is in favour of renewable energy (or any other development) as long as it is nowhere near their own residence. It has become unfashionable for social scientists to give credence to this explanation. Instead, researchers strive to understand opponents on their own terms and not presume actions as selfish or deviant [2]. Nevertheless, survey results often show the NIMBY position is present at low levels in host communities [276, 287, 288], and some argue that NIMBY is a rational reaction for some individuals that should be recognized via policies that attempt to quantify any costs incurred by those living in proximity to a renewable energy project and arrange for compensation [53].

Important conceptual critiques of the term "social acceptance" have been made by Batel et al., who point out that academic research tends to erroneously conflate acceptance with support [16]. They show that residents react differently when asked if they would accept an energy project versus when asked if they support an energy project. Acceptance implies a more passive relationship to an energy project. Walker and Cass make the further observation that academic research (and policy-makers) tend to view the public as supporters, opponents or somewhere in the middle of that spectrum [275]. They point out that there are many additional roles for members of the public. For example, the public may potentially be service users, investors, owners, lessees of land or buildings upon which energy generation equipment is hosted, captive consumers, protesters and more. The point is that acceptance and support imply a degree of agency that is not necessarily realistic. The geography of centralized energy distribution, for example of a 200 megawatt wind farm feeding electricity into a regional grid, involves thousands of disparate members of the public who may be totally unaware of their use of renewable sources of energy. In this sense, active acceptance is an imprecise term for the many forms of social relations that exist as renewables develop.

It is important to point out that, while the renewable energy literature has been slow to adopt the terminology of social licence, there are some notable exceptions [55, 134]. Hall and Jeanneret subsume their use of the term to the larger concept of corporate social responsibility and adopt the definition of social licence to operate provided by Thomson and Boutilier [261] of "ongoing acceptance or approval for a development granted by the local community and other stakeholders" [134]. Hall and Jeanneret's exploratory study found wind developers in Australia interpreted the term as obligations for authentic community engagement.

Despite a lack of attention to the term "social licence" in the renewable energy literature, several authors conceive local opposition as serving a necessary political function in the same way implied by the use of the legal/political term "licence." For example, Barry and Ellis argue for new planning models that minimize the exercise of arbitrary authority to approve renewable energy generation facilities [15]. Ellis et al. argue that dissent serves an important purpose in democracies and that the critiques of renewable energy development can inform better societal decision-making [87]. Thus, the social acceptance or social gap concept relates closely to social licence in a shared emphasis on issues of legitimacy. 


\section{TABLE 3 SCHOLARLY IMPACT OF THE TRIANGLE MODEL}

\begin{tabular}{|c|c|c|c|}
\hline Authors & Date & Format & Citations \\
\hline [287] Wolsink & 2000 & Peer-reviewed article & 553 \\
\hline [19] Bell, Gray \& Haggett & 2005 & Peer-reviewed article & 386 \\
\hline [70] Devine-Wright & 2005 & Peer-reviewed article & 604 \\
\hline [272] Van der Horst & 2007 & Peer-reviewed article & 379 \\
\hline [288] Wolsink & 2007 & Peer-reviewed article & 541 \\
\hline [291] Wüstenhagen, Wolsink \& Bürer & 2007 & Peer-reviewed article & 808 \\
\hline [2] Aitken & 2010 & Peer-reviewed article & 115 \\
\hline [16] Batel, Devine-Wright \& Tangeland & 2013 & Peer-reviewed article & 50 \\
\hline [20] Bell, Gray, Haggett \& Swaffield & 2013 & Peer-reviewed article & 49 \\
\hline [101] Fortin \& Fournis & 2014 & Peer-reviewed article & 9 \\
\hline \multicolumn{3}{|l|}{ Totals } & 3,494 \\
\hline
\end{tabular}

Note: Citation counts from Google Scholar, May 1, 2016.

\subsection{Social Licence as Legitimacy}

Despite their very different origins, all three varieties of social licence invoke a common concept: legitimacy. In some ways, this is hardly surprising. The concept of legitimacy "dates back to the dawn of organization theory" [62]. Max Weber is typically credited with introducing the term into social theory, and for linking legitimacy with conformity to social norms and formal laws [283]. Scott echoed these themes in his ground-breaking book: "Legitimacy is not a commodity to be possessed or exchanged but a condition reflecting cultural alignment, normative support, or consonance with relevant rules or laws" [248]. However, it was Suchman who offered what has become perhaps the most widely cited definition of legitimacy: "a generalized perception or assumption that the actions of an entity are desirable, proper, or appropriate within some socially constructed system of norms, values, beliefs, and definitions" [256]. Legitimacy is now a widely studied and cited concept throughout the social sciences. For instance, a cross-section of six publications ranging in age from nearly a century ago to a half-dozen years ago has been cited some 47,140 times (see Table 4).

In their classic work, Dowling and Pfeffer distinguished between three interdependent categories of organizational action: those that are economic, those that are legal, and those that are legitimate [82]. As they noted, "a legitimate purpose will not necessarily ensure resource allocation, nor will resource allocation necessarily ensure legitimacy" [82: 124]. Similarly, although laws in a democratic society are likely correlated with societal norms and values, these correlations are apt to be partial. First, because changes in the two spheres may take place at differing speeds. Second, because contradictions are inherent in norms, whereas there is a greater presumption of consistency in legal frameworks. And third, societies may tolerate certain activities informally, but not give them legal sanction. In other words, their model presciently foreshadows many elements of the three varieties of social licence we have reviewed, especially the three-strand model and the triangle model. 
TABLE 4 SCHOLARLY IMPACT OF LEGITIMACY RESEARCH

\begin{tabular}{|l|l|l|c|}
\hline Authors & Date & Format & \multicolumn{1}{|c|}{ Citations } \\
\hline [283] Weber & 1922 & Scholarly book & 20,382 \\
\hline [82] Dowling \& Pfeffer & 1975 & Peer-reviewed article & 1,988 \\
\hline$[248]$ Scott & 1995 & Scholarly book & 14,959 \\
\hline$[256]$ Suchman & 1995 & Peer-reviewed article & 8,417 \\
\hline$[13]$ Bansal \& Clelland & 2004 & Peer-reviewed article & 702 \\
\hline [62] Deephouse \& Suchman & 2008 & Scholarly book chapter \\
\hline Totals & & & 692 \\
\hline
\end{tabular}

Note: Citation counts from Google Scholar, May 1, 2016.

Along the way, various dimensions of legitimacy have been articulated. Notably, Aldrich and Fiol differentiated cognitive legitimacy, or "the spread of knowledge about a new venture," from sociopolitical legitimacy, or "the process by which key stakeholders, the general public, key opinion leaders, or government officials accept a venture as appropriate and right, given existing norms and laws" [4]. Scott divided this latter dimension in two, resulting in three dimensions of legitimacy: regulative, normative and cognitive, each linked with one of his three institutional pillars [248]. Suchman also proposed a trichotomy comprised of cognitive, moral and pragmatic legitimacy [256]. He coupled these with two temporal distinctions (episodic versus continual) and two substantive foci (organizational actions versus organizational essences), resulting in 12 distinct legitimacy types [62]. In another study relevant to our focus, Bansal and Clelland proposed the concept of corporate environmental legitimacy, defined as "the generalized perception or assumption that a firm's corporate environmental performance is desirable, proper, or appropriate" [13]. Relative to the focus of this paper, what is striking is the extent to which the many definitions of legitimacy and social licence correspond (see Table 5). 


\begin{tabular}{|c|c|}
\hline Definitions of Legitimacy & Definitions of Social Licence \\
\hline $\begin{array}{l}\text { "Appraisal of action in terms of shared or common values in the context of the } \\
\text { involvement of the action in the social system." ([222] Parsons, 1960: 175) } \\
\text { Justification of organization's "right to exist." ([180] Maurer, 1971: 361) } \\
\text { Implied congruence with the cultural environment, with "the norms of } \\
\text { acceptable behavior in the larger social system." (Dowling \& Pfeffer, 1975: 122) } \\
\text { Activities that are accepted and expected within a context are then said to be } \\
\text { legitimate within that context. ([82] Pfeffer, 1981: 4) } \\
\text { Array of established cultural accounts that "provide explanations for existence." } \\
\text { ([186] Meyer \& Scott, 1983: 201) } \\
\text { "Social fitness." "([213] Oliver, 1991: 160) } \\
\text { A generalized perception of organizational actions as "desirable, proper or } \\
\text { appropriate within some socially constructed system of norms, values, beliefs } \\
\text { and definitions." ([256] Suchman, 1995: 574) } \\
\text { "The endorsement of an organization by social actors." ([61] Deephouse, 1996: } \\
\text { 1025) } \\
\text { "Acceptance of the organization by its environment." ([164] Kostova \& Zaheer, } \\
\text { 1999: 64) } \\
\text { "A social judgment of appropriateness, acceptance, and/or desirability." ([292] } \\
\text { Zimmerman \& Zeitz, 2002: 416) } \\
\text { "The level of social acceptability bestowed upon a set of activities or actors." } \\
\text { ([277] Washington \& Zajac, 2005: 284) } \\
\text { "The degree to which broader publics view a company's activities as socially } \\
\text { acceptable and desirable because its practices comply with industry norms and } \\
\text { broader societal expectations." ([238] Rindova, Pollock, \& Hayward, 2006: 55) }\end{array}$ & $\begin{array}{l}\text { "Having the approval, the broad acceptance of society to conduct its activities." } \\
\text { ([156] Joyce \& Thomson, 2000: 52) } \\
\text { Meeting "social expectations ... gaining support for the project from concerned } \\
\text { groups, or stakeholders, over and above meeting any legal requirements." ([33] } \\
\text { Business for Social Responsibility, 2003: 4) } \\
\text { When free, prior and informed consent of indigenous peoples has been } \\
\text { practised and where key stakeholders have access to transparent information. } \\
\text { (World Bank, 2004, as cited in [22] Bice 2014) } \\
\text { "The demands on and expectations for a business enterprise that emerge } \\
\text { from neighborhoods, environmental groups, community members, and other } \\
\text { elements of the surrounding civil society." ([132] Gunningham et al., 2004: 308) } \\
\text { "The idea that industrial facilities must comply with tacit expectations of } \\
\text { regulators, local communities, and the public in order to continue operations." } \\
\text { ([145] Howard-Grenville et al., 2008: 77) } \\
\text { "Ongoing approval within the local community and other stakeholders." ([261] } \\
\text { Thomson \& Boutilier, 2011: 1779) } \\
\text { "Society's moral and political approval, sufficiently widespread and stable to } \\
\text { allow legal approvals to proceed and to assure ongoing community support." } \\
\text { ([37] Canada West Foundation, 2013: 1) } \\
\text { "A form of social acceptance or approval ... a socially constructed perception } \\
\text { that your company or project has a legitimate place in the community." ([24] } \\
\text { Black, 2013: 15) } \\
\text { "Consists of gaining, nurturing, and renewing legitimacy with local groups, } \\
\text { stakeholders and communities." ([234] Raufflet et al., 2013: 2,229) } \\
\text { "Ongoing acceptance or approval from the local community and other } \\
\text { stakeholders." ([220] Parsons et al, 2014: 84) }\end{array}$ \\
\hline
\end{tabular}

Note: Legitimacy definitions adapted from p. 153 of A. Bitektine, "Toward a Theory of Social Judgments of Organizations: The Case of Legitimacy, Reputation, and Status," Academy of Management Review, 36(1), 2011, 151-179. Social licence definitions based on authors' analysis.

What Table 5 makes clear is that definitions of legitimacy and social licence have considerable, perhaps even complete, overlap. Put simply, social licence is legitimacy and legitimacy is social acceptability, and vice versa. In light of this insight, for the purposes of this report, we propose to understand these three terms - social licence, legitimacy and social acceptability — as essentially synonymous. As further support for this conceptualization, it is worth considering the French translation for social licence: acceptabilité sociale.

Although some authors have expressed concern that social licence considerations may result in undemocratic outcomes, in the sense that the few are able to win over the many, legitimacy research suggests the opposite is also possible: "We suspect that legitimacy need not be conferred by a large segment of society for the organization (or subject) to prosper" [225]. In other words, legitimacy is as much the cure as it is the culprit.

\subsection{First Nations and Social Licence}

The question of whether the term "social licence" applies to First Nations, Métis and Inuit peoples in Canada is critical to the exploration of the term's use. Social licence is not a legal 
licence in the normal sense of the word: it cannot be applied for, and there is no central authority that grants it. From the opposition side of a proposed project, social licence is a mechanism that can be used to defeat, influence, or negatively impact a proposed development project. From the proponents' and their supporters' side of a proposed project, social licence can be used as a mechanism to support project approval. One possible definition of social licence is the acceptance of a proposed development by those who live in the area and could be affected by this development. An example of this is Enbridge's proposed Northern Gateway project, a twin pipeline that would transport diluted bitumen from Bruderheim, Alberta to Kitimat, British Columbia. Many communities along the proposed pipeline told Enbridge that the pipeline development was not welcome; the implication is that it did not have sufficient social licence to proceed. Aboriginal people along the pipeline route were also opposed, and the resulting question is: Does social licence include Aboriginal people? Aboriginal people, according to section 35 of the Constitution Act, include First Nations, Métis and Inuit peoples of Canada. Each group will be considered separately in this section as they have different rights that must be considered independently.

\subsubsection{First Nations Right to Consultation and Accommodation}

In considering the applicability of the term "social licence" to First Nations, one must look to the rights of First Nations that have to be considered in any development on the lands and resources within their territories. These rights have been clearly delineated by the Supreme Court of Canada, which has made rulings about consultation, accommodation and consent in several cases, such as Haida Nation vs. British Columbia (Minister of Forests) ${ }^{16}$ in 2004, Mikisew Cree First Nation vs. Canada (Minister of Heritage) ${ }^{17}$ in 2005 and Rio Tinto Alcan Inc. vs. Carrier Sekani Tribal Council ${ }^{18}$ in 2010. The Haida Nation vs. British Columbia (Minister of Forests) case in particular has set out what the duty to consult is and what triggers that duty:

"The duty arises when the Crown has knowledge, real or constructive, of the potential existence of the Aboriginal right or title and contemplates conduct that might adversely affect it." ${ }^{\prime 19}$ [emphasis added]

Consultation is a good faith and reasonable information disclosure between the First Nation and government. The duty to consult occurs when there may be a potential to adversely affect the rights of the First Nation. This includes treaty rights, as established in Mikisew Cree First Nation vs. Canada (Minister of Heritage). It has the purpose of substantially addressing the First Nation interests at stake and the duty arises before legislation is enacted or action taken. Most importantly under the Crown's duty to consult is how to carry out the process:

"The Crown, acting honourably cannot cavalierly run roughshod over Aboriginal interests where claims affecting these interests are being seriously pursued in the

\footnotetext{
[133] Haida Nation v. British Columbia (Minister of Forests), 2004 SCC 73.

17 [187] Mikisew Cree First Nation v. Canada (Minister of Canadian Heritage), 2005 SCC 69.

18 [239] Rio Tinto Alcan Inc. v. Carrier Sekani Tribal Council, 2010 SCC 43.

19 [133] Haida Nation v. British Columbia (Minister of Forests), 2004 SCC 73, paragraph 35.
} 
process of treaty negotiation and proof. It must respect these potential, but yet unproven, interests ... To unilaterally exploit a claimed resource during the process of proving and resolve the Aboriginal claim to that resource, may be to deprive the aboriginal claimants of some or all of the benefit of the resource. That is not honourable." ${ }^{20}$ [emphasis added]

The Crown has a duty to consult that arises out of the honour of the Crown prior to proof of Aboriginal title and rights. Courts have said if there is any infringement on the cultural and economic interests of Aboriginal or treaty rights and title, governments must accommodate. The purpose of consultation is reconciliation and not simply the minimization of adverse impacts. During consultations, the Crown may continue to manage the resource in question.

\subsubsection{First Nations Right of Consent}

In the 1997 case of Delgamuukw vs. British Columbia, ${ }^{21}$ the Supreme Court of Canada stated that where rights were affected, consent was required. This was elaborated upon in Haida Nation vs. British Columbia (Minister of Forests), which said that where there were proven rights, there was a right of consent. There is room for exceptions, however - as the court also ruled that the Crown has to balance all interests. Unfortunately, many First Nations do not trust the Crown to fully balance their treaty rights against the economic benefits of further development; a recent example being the Treaty 8 First Nations affected by the potential development of the Site C dam in the Peace River Valley. ${ }^{22}$ In the Supreme Court Case of Tsilhqot'in Nation vs. British Columbia (2014), the ruling stated that First Nations views must now be included in determining the balancing of interests. ${ }^{23}$ Ultimately, though, it is the Crown that decides what that balance is.

Tsilhqot'in vs. British Columbia further ruled that, on lands where Aboriginal title has been proved, the consent of the First Nation is needed. ${ }^{24}$ On lands where Aboriginal title has not been proved and the government wants to avoid a charge of infringement or failure to consent, the government should seek the consent of the First Nations. ${ }^{25}$ The court did say that even if a First Nation did not consent on proven Aboriginal title lands, the government could overrule it, but only on very strict grounds. ${ }^{26}$ These strict grounds are as follows: $:{ }^{27}$

(1) That it discharged its procedural duty to consult and accommodate;

(2) That its actions were backed by a compelling and substantial objective; and

(3) That the governmental action is consistent with the Crown's fiduciary obligation to the group.

\footnotetext{
[133] Haida Nation v. British Columbia (Minister of Forests), 2004 SCC 73, paragraph 27.

21 [66] Delgamuukw v. British Columbia, [1997] 3 SCR 1010, paragraph 168.

22 See [170] J. Lavoie, “Site C Dam is Final Straw for B.C.'s Treaty 8 First Nations,” Desmog Canada, July 3, 2014.

23 [268] Tsilhqot'in Nation v. British Columbia, 2014 SCC 44, paragraphs 81-84.

24 Ibid, paragraph 76

25 Ibid, paragraph 80.

26 Ibid.

27 Ibid, paragraph 7.
} 
Consistent with the fiduciary obligation means respecting the nature of the collective right: infringement cannot substantially deprive future generations of the benefit of title; there must be a rational connection to the objective; there must be minimal impairment to rights; and the benefits must outweigh the adverse impact.

\subsubsection{First Nations Rights vs. Social Licence}

This brief summation of the First Nations right to consent or to be consulted illustrates that these rights go far beyond the concept of social licence discussed above. First Nations are owed a legal duty to be consulted and at times their consent is needed. Adverse impacts on First Nations' rights can stop a project. A recent example of this is the case of Taseko's Prosperity Mine. ${ }^{28}$ The federal government determined that the mine would have adverse effects on Aboriginal rights and should not be developed..$^{29}$ The term "social licence" does not include a legal duty or obligation of the government or company to the public or other interested groups. Rather, social licence is considered to be for stakeholders or the general public, and is focused on the general public's desire to have or not have a project in their area. Social licence does not include a right of consent. Social licence will only be able to prevent the development of a project if opponents can elevate the profile of their issues enough to create sufficient public support and political pressure. There is no formal process for the public to have a say beyond what is in national and provincial regulatory processes.

First Nations are rights holders, not stakeholders. The applicable regulatory regimes determine what input various stakeholders and the general public have, and this is currently restricted to those who will be directly impacted by a particular development. There may be open houses to provide input from the general public (as in the environmental assessment process) but largely there is very limited opportunity to raise concerns formally about a project. For example, under the National Energy Board process, section 55.2 of the NEB $\mathrm{Act}^{30}$ sets out that the Board shall consider the representations of any person, who, in the Board's opinion, is directly affected by the application. The person must also have relevant information or expertise. A person may be an individual, company, organization or group. The Board's decision is final.

If people, groups or ENGOs are not able to achieve standing to participate in a regulatory process, they can make use of media and social media, protests, forums, petitions and other such methods to create pressure against a project. Often, First Nations are a part of these processes and work together for the common goal of stopping a project. This does not mean that social licence applies to them. Even as they stand together on the common goal of stopping a project, First Nations as rights holders have greater rights and more say than stakeholders. Many stakeholders believe that First Nations can actually stop a project based on their rights and have come to rely on them to do so and strongly support them.

28 [39] Canadian Environmental Assessment Agency, "Decision Statement," Feb. 25, 2014.

29 [38] Canadian Environmental Assessment Agency, "Report of the Federal Review Panel: New Prosperity Gold-Copper Mine Project," Oct. 31, 2013.

30 National Energy Board Act R.S.C., 1985, c. N-7. 
Enbridge's Northern Gateway is an example of a project that has had public opposition, which could be indicative of the project lacking social licence. ${ }^{31}$ Groups opposed include several First Nations, environmental groups and unions. ${ }^{32}$ Celebrities such as Jane Fonda and Neil Young have publicly condemned the development of the pipeline. ${ }^{33}$ The towns of Prince Rupert, Terrace, Smithers and Kitimat have held referendums - the results of which were clear opposition to the pipeline being built near their respective communities. ${ }^{34}$ Northern Gateway does not have First Nation consent and approximately 150 First Nations have spoken out against the project..$^{35}$ Many First Nations appeared before the National Energy Board Joint Review Panel in opposition to the project. Even in the face of significant opposition from towns, individuals, environmental groups and First Nations, ${ }^{36}$ the panel recommended that the project proceed with 209 conditions. The recommendation with conditions was approved by the federal government despite disagreement by the province of B.C. ${ }^{37}$ Opposition to Northern Gateway has continued after federal approval, with several opponents funding the court challenges put forth by several First Nations. ${ }^{38}$ If Northern Gateway were to proceed with construction, it would likely be in the face of significant public opposition and protest. Many doubt that the Northern Gateway project will actually go ahead.

First Nations, citizens groups, environmental groups and interested people can unite in a common cause and so First Nations get drawn into the concept of social licence. Getting involved with other groups in communicating their issues with a development project does not in any way take away from a First Nation's right to consent or to be consulted, nor does it prevent them from being part of the social licence actions of different groups of people.

\subsubsection{Consultations with Métis People}

The law relating to consultation with Métis people is not as developed as that of First Nations. Who is Métis, what their rights are, and whether Métis people are under the jurisdiction of the federal or provincial government are still being determined by the courts. The Supreme Court of Canada, in R. vs. Powley, ${ }^{39}$ dealt with the Métis community around Sault St. Marie and determined that they have a right to hunt and gave guidelines for other Métis across Canada on how to prove a right to hunt.

31 See [51] M. Chisholm, "Former BC Hydro CEO condemns Condemns Enbridge's 'Bogus Economics"” at Joint Review Panel," Vancouver Observer, Jan. 15, 2013; [144] G. Hoekstra, "Majority of British Columbians Ooppose Northern Gateway Pipeline: Poll," Vancouver Sun, Feb. 5, 2014; [217] T. Orton, "BC Nature Files Legal Challenge Against Enbridge's Northern Gateway Pipeline," Business in Vancouver, July 13, 2014.

[249] Sierra Club BC, “Opposition to Enbridge Grows since Federal Approval,” press release, June 15, 2015.

[49] CBC News, "Neil Young Calls Pipeline Issues 'Scabs on People's Lives',” Nov. 10, 2014.

34 [241] R. Rowland, “Kitimat residents Residents Vote 'No' in Pipeline Plebiscite,” The Globe and Mail, April 13, 2014.

35 [278] "First Nations who Oppose Enbridge," Watershed Sentinel.

36 [112] D. Gillis, "Enbridge Won’t Take 'No' for an Answer, Despite 96\% Opposition,” June 18, 2013, The Common Sense Canadian, June 18, 2013.

38 [249] Sierra Club BC, "Opposition to Enbridge Grows..."

39 [233] R. v. Powley, 2003 SCC 43. 
The other defining case dealing with Métis people is Daniels vs. Canada ${ }^{40}$ that went to both the Federal Court of Appeal and the Supreme Court of Canada. The main issue before the courts was whether Métis and non-status Indians are "Indians" as the term is used within section 91(24) of the Constitution Act, 1867. The plaintiff Métis asked the court for a declaration that they are owed a duty to be consulted in good faith respecting their rights, interest and needs as Aboriginal peoples. The Supreme Court of Canada upheld the declaration that "Indian" is "a broad term referring to all Indigenous peoples in Canada", but declared that there was no "practical utility" in issuing the other declarations relating to fiduciary duty and the duty to consult, as those questions "would be a restatement of the existing law" [60].

Métis rights are in the process of being defined by courts, but if a group of Métis peoples can fall under the definition of Métis, and show they have rights that may be negatively impacted by a proposed project, they should be consulted. ${ }^{41}$ As an example, the government of Alberta's policy on consultation with Métis communities, states the following:

“Alberta recognizes a duty to consult with some Métis communities when Crown land management and resource development decisions may adversely impact their traditional uses. The Province currently does not have a Métis consultation policy but has put in place an internal process to guide consultation with Métis communities on a case-bycase basis where there is a credible assertion of Métis Aboriginal rights. Any policy developed with Métis will be consistent with The Government of Alberta's Policy on Consultation with First Nations on Land and Natural Resource Management, 2013" [3].

One could conclude that some Métis would fall under the right to be consulted and others would fall under social licence, determined by whether they are legally defined as Métis and whether their rights, if any, will be negatively impacted. Until a more thorough definition of Métis rights is determined, it is likely that decisions regarding Métis rights will be on a case-by-case basis.

\subsubsection{Inuit Right to Consultation}

The Inuit who live within Nunavut negotiated a land claims agreement with the government of Canada that defined their rights. ${ }^{42}$ The preamble of this agreement states that the objective of the land claims agreement is "to provide for certainty and clarity of rights to ownership and use of lands and resources, and of rights for Inuit to participate in decisionmaking concerning the use, management and conservation of land, water and resources, including the offshore; [and] to provide Inuit with wildlife harvesting rights and rights to participate in decision-making concerning wildlife harvesting."

This land claim agreement is protected under s. 35 of the Constitution Act. The agreement sets out when the Inuit will be consulted through various sections of the agreement. In particular, article 27 talks of consultation on natural resources, which includes petroleum,

40 [60] Daniels v. Canada, 2016 SCC 12.

41 [185] Métis Nation of Ontario, “Part 3: Establishing a Métis Right — The Powley Test," http://www.Métisnation.org/ harvesting/the-powley-story/establishing-a-Métis-right---the-powley-test

42 [119] Nunavut Land Claims Agreement Act, S.C. 1993, c. 29. 
other resources, and existing subsurface rights. There is also a list that outlines what the Inuit have the right to be consulted on, which includes hiring, labour relations, business opportunities, safety, health and hygiene, protection and conservation of archeological sites, environmental concerns, disruption of wildlife, information flow and liaison between Inuit and proponents regarding project management, participation and concerns. Throughout the agreement, there are many boards, which the Inuit are a part of, that are established for water, wildlife, land, and resource management. Similar to First Nations, the Inuit would have rights under this agreement that would take them outside of social licence, as they have defined rights to be consulted under their final agreement.

The Inuit of Labrador also entered into a land claims agreement with the government of Canada and Her Majesty the Queen in right of Newfoundland and Labrador. ${ }^{43}$ The right to be consulted is laid out in various chapters related to natural resources. In particular, chapter 5 provides for consultation on ocean management. Section 5.6.7 requires the need for an impact benefit agreement before any major development. Chapter 10 sets out how land use planning will be done. As with the Inuit of Nunavut, the Inuit of Labrador have specific legal rights on any proposed energy developments that would be more than social licence.

The Inuit of Quebec are part of the James Bay and Northern Quebec Land Claim Agreement with the governments of Canada and Quebec. ${ }^{44}$ Chapters 22 and 23 are the main chapters that set out how any development shall occur with the Cree and Inuit people who are within the claim area. Their right to be consulted is very specific in an agreement that is protected by s. 35 of the Constitution Act, which goes beyond social licence.

\subsubsection{International Law and Free, Prior and Informed Consent}

The United Nations Universal Declaration of Indigenous Rights ${ }^{45}$ was adopted in 2007. This declaration is not a legally binding document but does set international norms for state conduct. The concept of Free, Prior and Informed Consent (FPIC) is utilized in articles 10, 11, 28, 29 and 32. Article 32 is in regards to development on lands, which reads:

1. Indigenous peoples have the right to determine and develop priorities and strategies for the development of their lands or territories and other resources.

2. States shall consult and co-operate in good faith with the Indigenous peoples concerned through their own representative institutions in order to obtain their free, prior and informed consent prior to the approval of any project, affecting their lands or territories and other resources, particularly in connection with the development, utilization or exploitation of mineral, water or other resources. [emphasis added]

43 [118] Land Claims Agreement Between the Inuit of Labrador and Her Majesty the Queen in Right of Newfoundland and Labrador and Her Majesty the Queen in Right of Canada.

44 [121] Government of Canada, "The James Bay and Northern Quebec Agreement."

45 [269] United Nations, "United Nations Declaration on the Rights of Indigenous Peoples," March 2008. 
3. States shall provide effective mechanisms for just and fair redress for any such activities, and appropriate measures shall be taken to mitigate adverse environmental, economic, social, cultural or spiritual impact.

The other articles relate to receiving indigenous peoples' free, prior and informed consent before adopting and implementing legislative or administrative measures that may affect them: no relocation; redress and restitution for any cultural, intellectual, religious and spiritual property taken without their FPIC; nor any storage or disposal of hazardous material on indigenous people's lands without their FPIC.

First Nations people in Canada have been pursuing the implementation of the term "free, prior and informed consent" as it pertains to any development within their territories and the use of their resources. The United Nations has been encouraging countries to have new legislation and mechanisms for dialogue with indigenous peoples, but admits that the "Promise of the Declaration is far from being universally fulfilled ... Rights of indigenous peoples are frequently the first victims of development activities in indigenous lands, often pursued with no regard to the principle of free, prior and informed consent ..." [270]. The mechanism of free, prior and informed consent is not one that has been implemented within Canada, but by international law standards, it has been accepted as the norm. Comparing and contrasting free, prior and informed consent with social licence also shows how strong internationally recognized rights of indigenous peoples are as compared with social licence.

Whether it is through national or international law, indigenous rights are critical to whether projects can be developed in their territories and these rights go far beyond social licence. Indigenous rights are at the core or root of every project in Canada that has to consider the impacts on the way of life, constitutionally protected rights and title of the Aboriginal people within Canada. If Aboriginal people are part of social licence, it can only be considered in addition to their rights.

\subsection{Why has the term "Social Licence" Emerged?}

In the exploration of social licence and public acceptance, the question of why the term "social licence" emerged is important to explore to put the issue in context. The term "social licence" has become known as a way to describe the public's acceptance or opposition of development projects or industries in their local area. The context in which the term is used is rapidly changing and is described in many ways, as described in section 3.1 above and in the media. ${ }^{46}$ In the most basic sense, people have become concerned with what is happening in their area or in proximity to where they live or work and the potential effects on their quality of life, including health and safety concerns, economic benefits and costs, and environmental and social impacts. The various phrases used have evolved with a need to further describe what the role of the public is in the development process.

Broad opposition to projects dates back at least as far as 1971 when the Don't Make a Wave Committee (later Greenpeace) in Vancouver sent a ship to Amchitka, Alaska to oppose

46 [45] D. Cayo, "Demand for 'Social Licence' Stems from Distrust of Private and Public Institutions," Calgary Herald, Dec. 10, 2014 
U.S. testing of nuclear devices. ${ }^{47}$ At this time, the term "social licence" was not in use. In the past, social licence could have been referred to as NIMBYism, or not-in-my-backyard syndrome (discussed in section 3.1.3). Peter Sandman states that "NIMBY" was used in print for the first time in 1980 in the Christian Science Monitor [245]. Another source states NIMBY was coined in the 1980s by British politician Nicholas Ridley, and was used to "describe citizens that oppose proposed real estate developments in their neighborhood or town" [205].

According to Sandman, NIMBY is defined thusly: "The purest, most literal example of the NIMBY attitude is opposition to something that virtually everyone (including the opponents) agrees ought to be built somewhere, but virtually everyone would prefer not to live near it. Examples include airports, jazz clubs, superhighways, slaughterhouses, prisons, and wind farms. These are all developments that offer significant benefits to the overall community at the possible expense of their nearest neighbors. They bring with them noise, odour, pollution, traffic, crime, or other undesirable side-effects. Opposing them is certainly not irrational, though it is demonstrably selfish (that is, rationally self-interested)" [245]. Sandman also uses the term NIABY, not-in-anyone's-backyard, where there is total opposition to a type of project. An example of this is those who are opposed to the expansion of the oil sands, or pipelines and tankers. Social licence can be argued to be a combination of both NIMBY and NIABY, as NIMBY is too narrow of a definition.

As outlined above, the phrase "social licence to operate" was coined in the late 1990s by Canadian mining executive Jim Cooney and has continued to be used in many contexts since. ${ }^{48}$ What "social licence" actually means has been the topic of much discussion. It is has been used often since the late 1990s. The more it is used, the more the concept becomes ingrained in our everyday lives. The phrase "social licence" is being used by natural resource project proponents, politicians, policy-makers, ENGOs, the public and media. ${ }^{49}$ It is now being used broadly by industry as well as the public. This is reflected in an opinion piece by Nigel Bankes: "While one would expect the concept to be enthusiastically endorsed by elements of civil society it is perhaps more surprising to see industry broadly endorsing the concept, including pipeline companies, industry associations (e.g., the Canadian Association of Petroleum Producers (CAPP) and Canadian Energy Pipeline Association (CEPA)) and even some regulators" [12]. As well, the term "corporate social responsibility" is sometimes referred to as the same or similar to the social licence to operate by companies themselves. ${ }^{50}$

[130] Greenpeace, "History \& Mission.”

48 For example, see [12] N. Bankes, “The Social Licence to Operate: Mind the Gap," ABlawg, June 24, 2015; [190] MiningFacts.org, "What is the Social Licence to Operate (SLO)?,"; and [203] D. Newman, "Be Careful What You Wish For: Why Some Versions of 'Social Licence' are Unlicenced and May Be Anti-Social," Macdonald Laurier Institute Commentary, November 2014. 
The emergence of the term "social licence" has been described in a paper from New Zealand's Sustainable Business Council as arising from such things as [257]:

- “Society's confidence in business has been shaken. The global financial crisis ... a massive destruction of personal wealth, and unemployment at historically high levels called into question the right of business to operate in such an apparently uncontrolled and unregulated manner";

- "A series of environmental disasters such as the BP Gulf of Mexico oil spill and human rights issues ... in the Bangladesh garment manufacturing industry ... undermine confidence that business would do the right thing if left to its own devices";

- "Global consumers have greater expectations for the role companies should play in giving back to society and addressing social and environmental issues";

- "Technological advances mean that information on a company can spread fast. NGOs are getting more active about ranking and publicizing business performance and will target particular companies and particular issues by organizing consumer boycotts."

Issues such as greenhouse gas emissions, climate change, and the potential effects of projects on the quality of water and air, are all reasons affecting why a term like social licence has emerged and is used so widely. Katherine Teh-White, the managing director of Futureye, a Melbourne-based management consultancy, said quite plainly that the period of community apathy and acceptance is over [260].

\subsection{Measuring Social Licence and Social Acceptance}

This section describes explicit attempts to measure social licence. Rather than an exhaustive overview of the work in this area, we have tried to be indicative of the work that has been done. While several notable attempts have been made, on the whole, considerable work remains to be done to improve the validity and reliability of such measures. Our review is not intended as an endorsement of these measurement techniques, but to give an overview of extant attempts.

Additionally, as our review makes clear, prior work has focused on measuring social licence in mining projects; to our knowledge, there are no attempts to measure social licence per se in the context of energy projects. Keeping this context in mind is important; the substantial differences between mining and energy projects could limit the usability of this section to most readers. In particular, the mining projects in question had mainly local effects and tended to take place in less-developed countries, whereas the discourse around energy projects in Canada has focused on local effects, impacts on climate change from energy development, and the legitimacy and fairness of the regulatory process. While measurement of social licence in the context of mining may not help in improving our understanding of the term as it applies to energy projects, it is still important to consider.

Although some have lamented that social licence to operate is intangible [261], as with any social scientific concept numerous measurement options exist. Of course, how to measure something depends on the definition of the construct in question. For instance, because the pyramid model, as described in section 3.1.1, assumes that "social licence has levels" 
[24], its proponents have attempted to demonstrate these levels empirically. In particular, the latest version of the pyramid model was reportedly inspired by Minera San Cristobal, a lead, silver and zinc mine in Bolivia [29]. The authors tracked changes in social capital during a 14-year period from 1994 to 2008 (see Figure 4), using "historical documents and the experience of persons who had been present throughout the life of the project using a basket of indicators and then verified through interviews with community members" [261].

In 2009, the authors devised "a pool of two dozen statements intended to measure the social licence to operate in interviews with mine stakeholders in Bolivia ... However, the subsets of statements meant to measure the separate layers of the social licence to operate did not display the cumulative nature hypothesized by Thomson and Boutilier [2011]" [261]. In light of these findings, in 2010 the authors revised the pool of questions for use in Mexico and Australia. Finally, in 2011, a set of 15 revised items was tested, again at the Minera San Cristobal mine. The 15 statements loaded on four factors, which the authors interpreted as economic legitimacy, socio-political legitimacy, interactional trust and institutionalized trust.

FIGURE 4 SOCIAL CAPITAL AT THE SAN CRISTOBAL MINE, 1994-2008

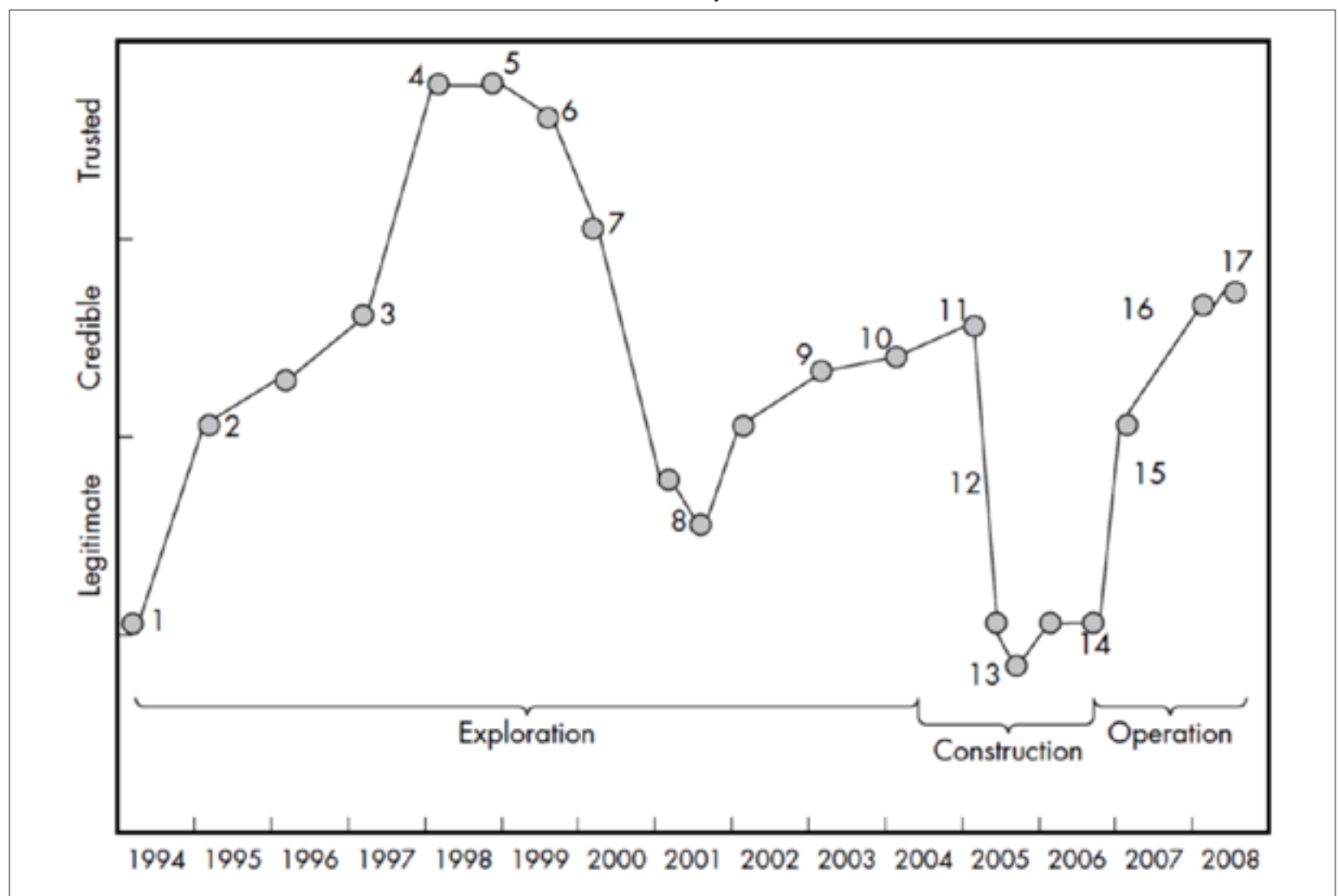

Source: p. 1792 of [261] I. Thomson and R. Boutilier, "Social Licence to Operate," SME Mining Engineering Handbook, $3^{\text {rd }}$ edition, edited by P. Darling, (Englewood, CO: Society for Mining, Metallurgy and Exploration, 2011), 1779-1796.

According to the authors, 85 per cent of cases conformed to a modified cumulative scale. For instance, stakeholders with a high score on the institutionalized trust factor "will always have high scores on all the other factors" [29]. Conversely, stakeholders with low scores on the socio-political legitimacy factor and the interactional trust factor "will never 
have high scores on institutionalized trust" [261]. Similarly, stakeholders with low scores on the economic legitimacy factor "will never have high scores on any of the other factors" [261].

Relative to the pyramid model, several points are noteworthy. First, contrary to the hypothesized model, Boutilier and Thomson [29] find no evidence for credibility as a separate factor between legitimacy and trust. Instead, they argue that socio-political legitimacy and interaction trust form a middle ground between mere economic legitimacy on the one hand, and institutionalized trust on the other hand. Second, neither Boutilier and Thomson [29] nor Black [24] provide any evidence for the reliability or validity of their specific questionnaire items or factor labels. Further work is needed to demonstrate whether the four factors they have found reliably and validly assess their proposed constructs. Third, the case study of the Minera San Cristobal mine introduces further conceptual slippage. Specifically, they claimed to measure "the ups and downs of social capital" [261]. But no justification is given for the subsequent conflation of social capital and social licence. Fourth, Boutilier and Thomson [29] interpret their factors as cumulative. Namely, they argue that institutionalized trust depends upon the presence of their other three factors. Or, more generally, that legitimacy is a necessary but not sufficient condition for trust. But to the extent that social licence is defined as legitimacy, then Boutilier and Thomson's proposed measures would appear to have limited construct validity [9, 25].

More recently, Black proposed measuring the pyramid model using 14 statements (see Table 6), which are rated on a five-point Likert scale, where 1 represents strong disagreement and 5 represents strong agreement: "To calculate a social licence score, calculate the mean of each stakeholder's responses to the group of questions. If you have many stakeholders you could group them into categories that make sense, for example, local government, environmental action groups, and so on" [24]. Additionally, Black recommends examining the standard deviation in the scores within the categories: "Wide variation suggests an 'average' score might be hiding some important differences between stakeholders that would be useful to know about for developing strategies." Additionally, when grouping stakeholders, it is necessary to identify criteria so that the differences between the groups are bigger than the differences within the groups. According to Black these social licence measures have been used with around 5,000 stakeholders in 60 projects. 


\section{TABLE 6 QUESTIONS FOR MEASURING SOCIAL LICENCE AS DEFINED BY THE PYRAMID MODEL}

\begin{tabular}{|c|c|}
\hline Item & Statement \\
\hline 1 & We can gain from a relationship with [name of company]. \\
\hline 2 & We need to have the co-operation of [name of company] to reach our most important goals. \\
\hline 3 & We are very satisfied with our relations with [name of company]. \\
\hline 4 & [Name of company] does what is says it will do in its relations with our organization. \\
\hline 5 & The presence of [name of company] is a benefit to us. \\
\hline 6 & [Name of company] listens to us. \\
\hline 7 & In the long term, [name of company] makes a contribution to the well-being of the entire region. \\
\hline 8 & [Name of company] treats everyone fairly. \\
\hline 9 & [Name of company] respects our way of doing things. \\
\hline 10 & Our organization and [name of company] have a similar vision for the future of this region. \\
\hline 11 & [Name of company] gives more support to those whom it negatively affects. \\
\hline 12 & [Name of company] shares decision-making with us. \\
\hline 13 & [Name of company] takes account of our interests. \\
\hline 14 & [Name of company] openly shares information that is relevant to us. \\
\hline
\end{tabular}

Source: [24] L. Black, The Social Licence to Operate: Your Management Framework for Complex Times, (London: Do Sustainability, 2013).

Starting in 2010, the Commonwealth Scientific and Industrial Research Organisation (CSIRO), Australia's national science agency (akin to Canada's NSERC), began studying social licence. ${ }^{51}$ Specifically, as part of its Mineral Resources Flagship program, CSIRO offers contract-based research to clients in business, industry and government regarding "social licence to operate." ${ }_{52}$ CSIRO takes the concept of social licence as its starting point. But rather than imposing one definition or another, CSIRO has conducted a series of studies as to how different stakeholder groups define the concept.

For instance, in a recent paper, Parsons and Moffat, two researchers from CSIRO, investigated how the mining industry constructed the meaning of social licence [221]. They began by collecting 62 sustainability reports published by 19 companies between 2006 and 2009. Within these reports, they identified 133 mentions of the terms social licence, social licence to operate and licence to operate. First, they analyzed the role of actors and agency within these mentions. In 111 instances, agency was either implicit or absent, making it unclear who is acting or facilitating action: "This vagueness suggests that social licence is essentially a metaphorical and rhetorical notion, bearing little resemblance to a licence in the legal sense." To further explore this possibility, they next analyzed the material processes associated with social licence. Specifically, they identified 121 instances where companies referred to acquiring $(n=32)$, maintaining $(n=83)$ or losing $(n=6)$ a social licence. Interestingly, the authors note that "no company discusses the prospect or consequences of failing to acquire a social licence."

In the same paper, Parsons and Moffat repeated their analysis using proceedings from a mining industry conference with the theme "sustaining our social licence." They found 30 mentions of social licence across 40 presentations and 35 abstracts. These mentions

\footnotetext{
51 The earliest CSIRO publication on "social licence" in the CSIRO Research Publications Repository is a presentation at the Sustainable Mining conference in Kalgoorlie, WA, Australia, Aug. 17-19, 2010.

52 [56] CSIRO, "Social Licence to Operate," March 1, 2015.
} 
were distributed unevenly. Mining companies represented 38 per cent of the speakers, and 47 per cent of the mentions; governments represented eight per cent of the speakers, and 20 per cent of the mentions; research institutions represented 18 per cent of the speakers, and seven per cent of mentions; and indigenous organizations represented eight per cent of the speakers, but none of the mentions. Thus, "social licence discourse has been adopted disproportionately within industry and government." As with the sustainability reports, agency was implied or missing in 28 out of the 30 mentions, and only processes of acquiring $(n=10)$ or maintaining $(n=20)$ a social licence were discussed. Overall, they conclude:

"Since not possessing a social licence appears to be almost inconceivable, the state of possessing a social licence becomes the default position. The burden of proof that a company does not hold a social licence seems to lie with a host community, broader society or some other stakeholder group. Since a social licence is so vague and intangible, it is relatively difficult to prove its absence, and relatively easy to assert and assume that one exists. Thus, the common argument that minerals companies today must hold a social licence may not confer a particularly onerous burden, and may not comprise the shift in power relations that the notion intuitively suggests" [221].

Whereas Boutilier et al [28] discussed how mining companies might use the pyramid model for instrumental purposes, namely acquiring and maintaining a social licence for their operations, Bice [22] investigated the extent to which mining company conceptions of social licence were (mis)aligned with the pyramid model. For instance, she studied how important social licence was from the company's perspective; whether, in their opinion, companies held a social licence or not; and how this had changed, if at all, over time. To do so, Bice conducted both content and discourse analyses of the 18 sustainability reports from five major Australian mining companies. Her analysis revealed that explicit discussion of social issues, as a percentage of all issues discussed, had almost quadrupled between the years 2004 to 2007 . The author concluded that while social licence is certainly important to the examined companies, how they go about determining if they have obtained it or not remains unclear.

In another CSIRO study, researchers focused on how mining companies engage with local communities, and how these processes affect the extent of their social licence to operate [191]. Broadly speaking, Moffat and Zhang proposed that company practices influenced trust, which in turn influenced approval and acceptance. In other words, they reversed the relationship between legitimacy and trust assumed by the pyramid model such that trust is antecedent to acceptance and approval (legitimacy). To test their model, they conducted two surveys. The participants included local residents living in the areas affected by an Australian coal seam gas operation (CSG, also known as coalbed methane) and not employed in the industry. They were recruited from a stakeholder database provided by a CSG company, and invited to complete a survey via the Internet. Both surveys asked questions on the impact on social infrastructure, contact quantity and quality with the company, procedural fairness, trust and acceptance. They found that impacts on social infrastructure, contact quality and perceived procedural fairness were correlated with trust, which was in turn correlated with acceptance. 
According to Lacey and Lamont, numbers can be equivocal [165]. For instance, in their study of coal seam gas development in Queensland, Australia, they found that industry proponents claimed it had a social licence on the basis of its success in securing more than 4,000 landholder access agreements. However, they note that "While individual contracts are necessary for negotiating the terms of company behaviour and responsibility when accessing private property for their activities, in and of themselves, they do not constitute evidence of the broader-based social agreement ... Rather, there are many people, including those in distal communities, who do not hold land affected by CSG development but who are democratically entitled to express their views ... Thus, it cannot be reliably concluded that 4,000 individual contracts provides an industry with a social licence."

Although these different efforts to measure social licence are no doubt interesting, more recently Owen and Kemp have criticized the mining industry's use of social licence for depending on a "circular logic" [218]. On their account, the concept is invoked by industry in an effort to demonstrate that it has met stakeholder expectations, whether or not it actually has responded to stakeholders' specific expectations. But companies and their stakeholders "invariably have different expectations." As a result, "social licence can be used to mask the gap between company and stakeholder expectations ... the industry's use of the term is interpreted here as an effort to disguise or silence opposition."

\subsection{Social Licence and Social Acceptance in the Context of Energy Projects}

The term "energy project" encompasses energy production from fossil fuel and renewable sources, as well as transportation infrastructure, yet both types of projects may invoke support or opposition for a range of different reasons. The term "social licence" has been attributed to some degree as the gatekeeper, with the power to influence having the greatest impact on the success or failure of energy projects. The term has been used when referring to both traditional and renewable energy projects; however, much of the attention and literature relating to social licence can be attributed to both renewable and nonrenewable energy. The government of New Brunswick, in its announcement to form a commission to address hydraulic fracturing, announced that a moratorium will exist unless certain criteria are met, the first one identified as "social licence" in order to proceed. ${ }^{53}$ Alternatively, a natural gas power plant project planned for Middletown, Ohio, appears to be finding support: the $\$ 500$ million US project is expected to create 400 local jobs. ${ }^{54}$

\subsubsection{Renewable Energy Projects}

The key drivers for the adoption of renewable energy are climate change and energy security. Climate change mitigation is a global concern with intergovernmental agreements in place to reduce greenhouse gas emissions, such as the recent Paris agreement. Energy security has the potential to impact economic growth and is affected by fossil fuel reserves, fluctuations in fuel process and uncertainty of supply. Although public opinion relating

\footnotetext{
53 See [125] Government of New Brunswick, "Government Introduces Moratorium on Hydraulic Fracturing in New Brunswick, press release, Dec. 18, 2014.

54 See [182] R. McCrabb, “\$500M Natural Gas Plant Planned for Middletown,” Dayton Daily News, Jan. $28,2014$.
} 
to renewable energy is reported in much of the literature to be supportive of the general concept of "green energy" and the inherent reduction in greenhouse gas emissions, there appears to be a significant disconnect when it comes to implementation, or community acceptance: the social gap, as described in section 3.1.3. This also seems to be true across geographical and technological boundaries with reports of support and opposition in many countries, which also span type and scale of energy project; wind, tidal, solar, biomass, geothermal, tidal and transmission scale, such as a multi-megawatt wind farm to local distributed or even residential developments.

Wind energy projects, and their success and failure, have arguably received the most attention in academic literature, perhaps due to the global growth in wind energy development in recent years. ${ }^{55}$ Significant research has been undertaken to address opposition to wind projects and to understand the motivation behind it [86]. Devine-Wright argues of the need for empirical research and proposes a multidimensional framework that transcends localized opposition, known colloquially as NIMBYism [70]. Wolsink considers public attitudes in Europe and identifies equity and fairness, not-in-my-backyard or NIMBY motives [288]. Cass and Walker consider emotion as a key psychological characteristic, which they suggest may impact the rational planning process [44]. Graham et al. [128], when evaluating public perception, did not identify a relationship between proximity and opposition to a proposal, but instead propose a wider range of factors influencing opposition, expanding Devine-Wright's [71] proposed framework.

Wind power, for example, is a major contributor to the provision of electricity from renewable energy and as of June 2014 has $337 \mathrm{GW}$ of installed wind capacity in over 100 countries, meeting four per cent of the world's electricity requirements. ${ }^{56}$ The European Union by the end of 2014 had $133.9 \mathrm{GW}$ of installed wind energy capacity, with the four main leaders identified as Germany (39 GW), Spain (22.9 GW), United Kingdom (12.4 GW) and France $(9.3 \mathrm{GW}) .{ }^{57}$ Denmark, with $4.8 \mathrm{GW}$ of generation capacity was able to meet 39 per cent of its electricity requirements in $2014 .{ }^{58}$ The U.S. has over 48,000 turbines, equating to $65.8 \mathrm{GW}$ of installed wind capacity ${ }^{59}$ and Canada has $9.7 \mathrm{GW}$ of installed capacity supplying approximately five per cent of Canada's electricity demand. The evidence suggests that wind energy is big business and is experiencing sustained and significant growth on a global basis. Although projects are moving ahead, challenges still exist when addressing the need for public acceptance, or legitimacy as described in the pyramid model, and one must consider if common themes exist between projects that receive support and those that experience opposition, as a function of geography, size and type of technology.

Acquiring social licence or public acceptance can often be difficult, and when it is not acquired can result in the cancellation of projects. Jami and Walsh provide an interesting case study on the Blue Highlands wind project in The Blue Mountains, Ontario [152].

\footnotetext{
See [290] World Wind Energy Association, "New Record in Worldwide Wind Installations," 2015.

56 See [289] World Wind Energy Association, 2014. World Wind Resource Assessment Report. WWEA Technical Paper Series (TP-01-14).

57 See [91] European Wind Energy Association, 2015. Wind in Power: 2014 European statistics.

58 See [106] K. Garus, "Denmark Breaks its Own Wind Record," Sun and Wind Energy Magazine, 2015.

59 See [7] American Wind Energy Association, 2015, "Wind Energy facts at a Glance."
} 
Brookfield Power, the project developer, proposed a two-phase, 77-wind-turbine project, including necessary support utilities, to be constructed in the town of The Blue Mountains. Phase 1 of the project was a $50 \mathrm{MW}$ wind farm, which was to begin construction in 2006 and be fully operational by March 2007, designed to meet the energy demands of 10,000 homes in the surrounding area. However, the project encountered over two years of delays due to opposition from the local community and as a result, Brookfield Power cancelled the project as it could not be completed within the timelines stipulated in the energy purchase contract.

This is not the only wind project in Ontario to be cancelled. Kingsbridge II in Goderich, Huron County, was also abandoned when faced with similar opposition. Research of host communities for wind farms by Baxter et al. found a majority of residents opposed to proposed projects in certain cases [17]. Concerns over health risks and landscape impacts are the strongest predictors of opposition. These concerns have been exacerbated by a narrowing of the requirements for community engagement by developers. Major wind projects are now subject to lengthy appeals by opponents to the provincial Environmental Review Tribunal, which not only introduce additional project financial costs but also foster socially costly community division [276].

While recognizing the disadvantages of public involvement in the energy project decisionmaking process, Jami and Walsh also comment on several possible benefits [152]. Involving the public in the decision-making process benefits public officials, as it places responsibility and accountability on the citizens and reduces the likelihood of unpopular policies. The authors even go so far as to say that it is necessary in "achieving the key principle of a democratic society to acknowledge the basic human rights regarding democracy and procedural justice."

Dusyk states that public involvement has the benefits of "the possibility of creating new, potentially more robust, forms of knowledge and helping to shape individual and collective identities" [83], citing a number of other authors including Fischer [97], Healey [138], Callon et al. [36], and Whatmore [285]. Dusyk examines the case of hydroelectricity in British Columbia, more specifically the Site C proposal on the Peace River. While the project was originally pitched in the early 1980 s, it was delayed and then cancelled in a similar manner to the wind projects discussed above. Dusyk states that the proposal of the project was a "learning opportunity for opponents of the project" and it "created a contingent of local residents who familiarized themselves with the issues and with effective forms of intervention." Interest in the project has resurfaced in recent years, but much of the public or their children who protested the proposal still live in the area, and there has been "a knowledge and cultural accumulation around Site C," which Dusyk says has translated to intelligent and informed advocacy.

Canada is not the only country to experience delays in wind projects. New Zealand has 19 wind farms, either in operation or under construction, amounting to five per cent of New Zealand's electricity generation capacity. There are 12 proposed additional farms, all of which have received regulatory approval, or consent to proceed; eight of these received consent following reviews as a result of opposition. Graham et al. published a case study based on three, at the time, proposed wind energy projects in New Zealand, at Whitehill, Hayes and Mahinerangi, all of which received regulatory approval or consent to build [128]. 
Whitehill proceeded with 90 per cent and 80 per cent public support (measured by opinion polls) from local and non-local residents respectively, yet Hayes and Mahinerangi were under appeal at the time of paper submission. Interestingly, Hayes received over 60 per cent support from local residents and less than 50 per cent by non-local residents. Mahinerangi received overwhelming opposition, with just under 90 per cent of local residents opposed and approximately 70 per cent of non-local residents opposed. A recent review of New Zealand's wind farms, as published by the New Zealand Wind Energy Association indicates that Hayes was never built, yet Mahinerangi was commissioned in 2011. ${ }^{60}$

Jobert et al. present examples of three successful projects in France and two in Germany, where again public support was assumed but social support at a local level was described as a challenge [154]. The authors choose a different approach and instead of using opinion polls to assess support, analyzed how implementation programs were constructed to understand why projects were supported or not, using the behaviour of stakeholders during the implementation phase as a guide. The authors indicate that trust, identified as the final boundary in the pyramid model, is one of the greatest barriers to gaining public support, something that was overcome in Germany by creating specific zones for wind development projects. Wind turbine development was given privileged status, yet communities were allowed to participate in the regulation and location of these zones. The authors report, however, that this trust has been eroded by overconfident and demanding developers. In France, a lack of stringent regulatory processes at the time of analysis led to procedural issues that often added confusion to public opinion. In all five cases, however, the projects were implemented. The authors conclude that a wider range of factors need to be considered, which they list as visual impact, ownership, information and participation along with local integration of the developer, the creation of network support and access to ownership.

Raven et al. provide a comparative analysis of 27 new energy projects in Europe, encompassing energy efficiency, bioenergy, wind, solar, hydrogen, geothermal and $\mathrm{CO}_{2}$ capture and storage [235]. The authors identify five crucial challenges and propose a sixstep methodology for facilitating societal acceptance for new and ongoing energy projects.

A wealth of published literature relates to energy economics, which tends to target the feasibility of projects, relating project costs and revenue to technology and ultimately resource availability, in an attempt to answer the question, "Is this renewable project economically feasible at this location, at this scale, given this resource?" $[18,146,173$, 196, 246]. Such analysis has been expanded to encompass ownership models, policy, and incentives such as feed-in tariffs and taxes. Despite the development of feed-in tariff policies globally and their impact on implementation, industry sectors, land use and environmental protection [59, 169, 195, 219], a recent study in Germany questions whether such policies actually cause innovation to stagnate [206].

In the case of tidal energy development, there are obvious first-to-market advantages. Uncertainties are reduced for investors, insurers and future project developers. Frontrunners can also often establish industry standards and impact subsequent project design. However, risks are often the greatest for front-runners given a lack of standard operating

60 See [202] New Zealand Wind Energy Association, Wind Farms Operating and Under Construction, 2015. 
procedures, a nascent supply chain, a lack of specialized infrastructure, and often community resistance [179]. Benefits can accrue from delaying energy projects, especially when projects involve new technology. Benefits from delay for tidal energy projects, especially for competitors who are not the front-runners, can include increased investor confidence as technology is improved, a regulatory process developed to address tidal energy development, and increased stakeholder awareness and confidence in the ability of developers and regulators to address their concerns.

Most renewable projects have time constraints from approval to implementation. Renewable projects are capital-intensive, large-scale civil engineering projects and have significant front-end costs; those associated with resources assessment, access, connectivity and meeting regulatory requirements such as environmental assessment. Failure to comply within the time constraint can result in the loss of regulatory approval or permission to proceed with significant financial implications.

\subsubsection{Fossil Fuel Projects}

Bowness and Hudson examine the outcomes of hearings held regarding citizens' concerns pertaining to oil sands projects in Alberta [30]. Of the 24 hearings that took place between 2005 and 2011, one resulted in withdrawal of a project, three resulted in amendments to project proposals (mostly additional monitoring requirements), and seven were settled outside of the hearings through negotiations between proponents and intervenors, so the resulting amendments are not publicly available. The rest of the hearings ruled in favour of the project proponents and so no changes were made.

Examining Quebec's Utica Shale, Rivard et al. found public involvement resulted in a de facto moratorium, rendering exploration projects by Talisman, Junex, Gastem and Forest Oil useless for the time being (the moratorium may stay in place up to 2018) [240]. In 2009, shale gas protests began, and since then 30 local, and three provincial, protest groups have formed. Sixty-three municipalities have also announced motions against shale gas development. In 2010, public hearings were held, and in 2011, new strict regulations were announced that caused industry activities to cease and the de facto moratorium.

Opposition causes delays, which will ultimately increase the cost associated with projects, reported by as much as 20 to 30 per cent in the case of coal stream gas exploration in Australia. ${ }^{61}$ A six-year delay in the Keystone XL pipeline has reportedly increased the cost of the project to $\$ 8$ billion from $\$ 4.5$ billion..$^{62} \mathrm{~A}$ joint report by the Institute for Energy Economics and Financial Analysis and Oil Change International states that anti-oil-sands campaigns have cost the industry over $\$ 17$ billion. ${ }^{63}$

\footnotetext{
61 See [230] B. Potter, “Opposition to Energy Projects Could Push up Bills,” Australian Financial Review, 2014, Accessed April 16, 2015.

62 See [193] G. Morgan, "Cost of Keystone XL has Jumped Nearly 50\% During Six Years of Delays, says TransCanada CEO," National Post, Nov. 4, 2014.

63 See [148] Institute for Energy Economics \& Financial Analysis, "Material Risks: How Public Accountability is Slowing Tar Sands Development," 2014.
} 
The press has also captured the economic impact of project delays. The Huffington Post reported that Lone Pine Resources Inc. has brought a \$250 million damage suit to a NAFTA panel against Canada due to the millions they lost because of the Quebec government's moratorium on hydraulic fracturing. ${ }^{64}$ A Globe and Mail article claims that Imperial Oil Ltd. estimates the cost of the Mackenzie Valley Project has increased to \$20 billion (an increase of 40 per cent) after several years of legal and regulatory delays. ${ }^{65}$ Much of this delay was due to negotiations with public stakeholders. ${ }^{66}$

The negative impact on a project's overall economic feasibility is true in many industries and has been the subject of significant research, as demonstrated by published literature. Fallahnejad addresses delays in traditional projects, specifically pipeline projects in Iran, referencing a range of other similar projects in Africa, Asia, Europe and North America [92]. Jergeas provides an analysis of cost overruns for oil sands projects in Alberta, but focuses on the pre-endorsement phases of such projects [153]. Although only some of this work acknowledges that delays can result from public opposition, much of the literature addresses delays caused by reasons other than opposition, such as poor management, site planning, design changes, design errors, weather, procurement, and labour issues, and in the identification and implementation of mitigation protocols [135, 211, 216, 244].

\subsubsection{A Closer Look: Ontario's Energy Regulatory Situation}

Ontario's energy regulatory situation features multiple oversight and planning bodies with differences between the natural gas ${ }^{67}$ and electricity sectors. In 1960, the Ontario Energy Board (OEB) was established as a quasi-judicial administrative tribunal charged with regulating the province's natural gas sector in the public interest. Its structure is similar to that of the National Energy Board with appointed panel members who hold oral and written hearings. The OEB's major focus is on ensuring fair pricing of energy commodities for consumers, with a lesser role in approving the siting of energy infrastructure. It reviews and approves changes to natural gas prices and regulates ownership changes and other aspects of market participants.

The Board also reviews applications for pipeline construction and for construction of electricity transmission lines within the province; however, it has no role in the approval of the siting or construction of the wind energy generation facilities which have proven to be contentious and have introduced questions of social acceptance and social licence. The OEB is also not performing any review function on another topic that attracts public debate and opposition: that of the plan for \$15 billion in upgrades to Ontario's nuclear generating stations.

The OEB's role in the electricity sector expanded in the late 1990s when Ontario's Crown corporation was restructured and broken into generating and transmission entities.

64 See [21] J. Beltrame, "Quebec Fracking Ban Lawsuit Shows Perils Of Free Trade Deals: Critics,” Huffington Post, Oct. 3 , 2013.

65 See [96] “Imperial Oil’s Mackenzie Pipeline Price Tag Swells to \$20-Billion,” Financial Post, Dec. 24, 2013.

66 See [155] J. Jones, “Mackenzie Valley’s New Price Tag: \$20-Billion (and rising),” Globe and Mail, Dec. $23,2013$.

67 As Ontario has limited production of natural gas, the Ontario Energy Board's main function in regulating natural gas is in transmission and consumption, rather than production. 
However, the OEB role in electricity is limited by two major factors. First, its major function of setting rates is limited to only transmission and distribution charges and not procurement for a large portion of generated energy. It sets rates for purchase of only nuclear and hydro power produced by the Crown corporation, Ontario Power Generation, and not for other market participants. Second, the electricity sector has been a site of more rapid policy change and more purposeful interaction from the provincial government than the natural gas sector.

The policy decisions taken under the Green Energy and Green Economy Act 2009 to prioritize solar, wind and other renewable sources of electricity came in the form of several ministerial directives to adjust rates and program rules. These decisions overrode longterm energy plans of the Ontario Power Authority (OPA), which nominally had authority for overall electricity planning. In a 2011 report, the auditor general of Ontario remarked that this has created ambiguity over the mandate of the Ontario Energy Board to review and approve energy plans prepared by the OPA. ${ }^{68}$ For some critics this is haphazard and problematic [114]. Further changes arose in 2015, when the OPA and its procurement and planning activities merged with a separate entity, the Independent Electricity System Operator (IESO), which has responsibility for overseeing the electricity market.

Host community protests and the rise of a social movement against wind energy in Ontario have challenged the traditional scope of the public interest for Ontario's energy regulators [17, 63, 142, 254]. For instance, the OEB's primary goal is to "to ensure that the public good is served in a marketplace that is not competitive" [214]. The impetus for regulatory oversight is thus economic and not social, environmental or public-safety related. It is limited to addressing the natural monopoly position that electricity and natural gas providers occupy and to acting as a substitute for the economic forces that would normally influence them in a competitive market. Economic regulation is also designed to provide oversight of the markets to protect consumers. The OEB's role as an economic regulator is to balance the interests of regulated entities and consumers" [214]. In contrast, the issues that are raised by host communities when new energy projects are developed are contextual, site-based and overwhelmingly based in environmental, public health and cultural (e.g., landscape and heritage) discourses.

For wind electricity generation in Ontario, these conflicting opinions and interest are regulated at two main points. First is the provincial authorities' decision to enter into a contract to purchase the electricity produced by a wind-generation facility. This decision is made by the IESO (formerly OPA). From 2010 to 2015, contracts were awarded if proponents could meet basic requirements of technical and financial capacity. Proponents then proceed to carry out environmental, noise, cultural and other assessments along with a minimum of two public meetings to seek a renewable energy approval (REA) from the Ministry of the Environment, representing the second major point of regulation.

Appeals of REA decisions are heard at the Environmental Review Tribunal, one of five tribunals and boards in the province that adjudicate on matters related to land use planning, environmental and heritage protection, property assessment, land valuation and other matters. Remarkably, all wind energy REAs issued from 2010 to 2015 have

68 See [8] Auditor General of Ontario, 2011 Auditor General Report, 67-86. 
been appealed to the Environmental Review Tribunal, one successfully, a case which is now before Ontario's Court of Appeal. In 2013, the ministry directed IESO and OPA to develop better ways to facilitate public engagement (opposition) with large renewable energy projects. The two bodies recommended better integration of the siting approval activities and the planning activities of government [215]. Now, new regional planning bodies involving municipalities and members of the public to consult on regional energy generation needs are being established. A second change is that IESO will require evidence of more community engagement from companies wishing to build wind energy projects prior to the offering of contracts. These changes arguably represent a significant expansion in the process and scope of defining and accommodating the public interest over energy in Ontario.

\subsubsection{Transferable Lessons from the Forestry Sector}

The energy sector is not the only Canadian sector to face challenges of social acceptance and related broader criticisms that regulation is failing to ensure extractive activities are carried out in the public interest. During the 1990s and early 2000s, the forestry sector went through dramatic regulatory and governance changes. Mass protests and two failed land use planning processes in coastal British Columbia, colloquially known as the "war in the woods" were followed by NGO-led boycott campaigns targeting major wood purchasers. This affected markets, not only in B.C., but throughout the rest of Canada and the United States. Forestry companies with a legal licence to log faced severe difficulty accessing markets. Some eventually agreed to adopt the logging and forest management requirements of NGO-backed third-party certification schemes. This, together with the setting aside of increased levels of protected areas, ended boycott campaigns and re-opened markets for certified wood. Thus, regulatory approval and legal licence to conduct forestry activities were significantly supplanted by separate non-state and market-driven legitimacy-granting processes [43]. The terminology of "social licence" had not yet appeared in popular, industry or academic circles, but the forest certification scenario created much of the same tensions and rhetoric employed today in the social licence discussion in the energy sector. Industry felt it unfair and unnecessary to go beyond regulatory requirements, government struggled to find efficient regulation amid increasing public protest, and significant segments of civil society criticized the legitimacy of conventionally practised resource extraction.

While the supply chain dynamics around oil, natural gas and electricity production are not the same as forest products, the process of how forest certification gained legitimacy in this scenario may be instructive. Cashore [42] has adopted Suchman's [256] concepts around organizational legitimacy to assess the process. He drew attention to three types of legitimacy that exist for a firm (and industry): pragmatic legitimacy; value-oriented moral legitimacy; and culturally based cognitive legitimacy. Cashore argues that the practical legitimacy of certification was easily attained because of the opportunity certification provided to re-open markets. He further argues that moral and cultural legitimacy remain in question and rest upon multiple factors, including fissures between previously supportive environmental groups and the rise of multiple competing certification schemes. However, in the years since Cashore's analysis, it appears certification is here to stay. The 
encouragement of forestry certification by provincial governments throughout Canada has contributed greatly to certification's cultural and moral legitimacy. One lesson to take from the forestry experience is that government's monopoly authority to regulate the energy sector is fragile, particularly if market access is threatened by negative evaluations of energy sector activities by NGOs or civil society.

\section{PUBLIC ACCEPTANCE AND THE CURRENT STATE OF THE REGULATORY PROCESS}

The goal of this section is to explore the influence of the concepts of social licence and public acceptance on energy project development and the regulatory process. A concept that originated in the mining sector, described in section 3.1.1 - social licence to operate - is used more and more often in the context of energy projects in Canada, but little is understood about how it applies (or whether it should apply) to these projects or their regulators. We explore the effects of apparent increased interest and opposition to energy projects by providing different arguments on the state of Canada's regulatory process.

\subsection{Case: The Regulatory Process is Broken}

With the rise of the use of the term "social licence" across Canada, a significant question needs to be asked: Is the regulatory process broken? There are federal, provincial and territorial regulatory processes that must be considered within this question. What does it take to break a regulatory process? Is it a legitimate regulatory process if there is no public confidence? Is it broken when there is great public outcry, and how much public outcry is required to say it is broken? Is it only broken when courts rule the laws are invalid or reverse a project decision? Is the regulatory process broken when it does not comply with the legal duty to consult and accommodate First Nations or seek their consent when that is required? When does the regulatory process lack democratic legitimacy? And, finally, who decides if the regulatory process is broken? A closer look at all these questions will explore this issue.

Recently, several energy projects that have been approved by the federal regulatory process are facing court challenges opposing this approval. Prominent examples include the Site $\mathrm{C}$ dam $^{69}$ in northeastern British Columbia, jointly assessed by the Canadian Environmental Assessment Agency and the B.C. Environmental Assessment Office, and Enbridge's Northern Gateway pipeline, ${ }^{70}$ reviewed by the National Energy Board. The fact that major projects such as these, which have been approved via the regulatory process, are facing

\footnotetext{
69 There were numerous challenges initiated, some of which have been subsequently dropped. See: [231] M. Preprost, "Two First Nations Withdraw from Fight Against Site C Dam," Business in Vancouver, July 20, 2015 three times, challenging the Joint Review Panel's decision, the Governor-in-Council's decision, and the Certificate of Public Convenience and Necessity issued by the board. These are clearly three separate court challenges, as they have three separate filing dates. However, if the question is "how many groups challenged this project" versus "how many court challenges were there," the answer is different, as some of the challenges have been consolidated. For more details, see [199] National Energy Board. 2015. "Court Challenges To National Energy Board or Governor in Council Decisions."
} 
such opposition suggests that the current regulatory process is not adequately accounting for social licence and is indeed broken. In addition, Kinder Morgan's proposed expansion of the Trans Mountain pipeline has been challenged during the regulatory process, as has TransCanada's proposed Energy East pipeline.

Through changes to the NEB Act introduced in Bill C-38 $38^{71}$ in June 2012, the previous federal government had been trying to streamline regulatory reviews and environmental processes. The changes to the legislation adjusted the definition of who can present at hearings held by the NEB, and set out firm timelines for the regulatory process that necessarily limit the number of people who can present. These changes include bounding the time allowed for hearings in the approval process of a pipeline proposal to 18 months, and significantly reducing the number of individuals who are able to testify at such hearings. The new criteria for being able to testify at an NEB hearing was: people who stand to be directly impacted by a proposed project, and people who have information and expertise that could help the hearing panel gain a greater understanding of a given matter under consideration. ${ }^{72}$ It is the Board itself that decides whether a person, company, organization or group has standing based on various criteria.

A comparison of the hearing processes for both the Enbridge Northern Gateway pipeline and the Kinder Morgan Trans Mountain pipeline show the effect that these changes have had. During the Northern Gateway project's Joint Review Panel process there were 77 days of community hearings in 21 communities. There were also 96 days of final hearings that took 10 months. The time invested in conducting these hearings was significant, but arguably allowed for a wider range of viewpoints to be heard. With the Kinder Morgan Trans Mountain pipeline, 2,118 people applied to participate; of the 852 who requested intervenor ${ }^{73}$ status, 400 received it and the rest were given commenter ${ }^{74}$ status; 798 requested commenter status, which was granted, and 468 were denied the ability to participate. ${ }^{75}$ A citizens' group is challenging this part of the NEB Act because it believes the definition for who is allowed to participate in the hearing process is now too narrow. ${ }^{76}$

This becomes a very pertinent issue in the question of regulatory legitimacy. The NEB's determination of who gets to present has the consequence of stratifying and prioritizing stakeholders into those who are directly affected, those who object on moral grounds and those who are indirectly affected. Who should have a voice is a key and critical issue and it will be interesting to see what the results of this court challenge will be.

Participants in the NEB hearings for the Trans Mountain pipeline were also denied the opportunity to cross-examine Kinder Morgan, the project proponent. It was felt this was

71 [120] Bill C-38, Jobs, Growth and Long-term Prosperity Act.

72 S. 55.2 National Energy Board Act.

73 Acting as an intervenor means the person participating "may have the opportunity to present written evidence, question others on their written evidence, cross-examine other witnesses at the oral portion of the hearing, and give final argument," as well as be questioned on evidence they present. See: [198] NEB, National Energy Board Hearing Process Handbook.

Acting as a commenter means the participant submits a letter of comment, but cannot ask questions of other participants' evidence or submit a final argument. See ibid.

75 See [197] National Energy Board, "Ruling on Participation,” Hearing Order OH-001-2014, 2 April 2014.

76 See [52] M. Chisholm, "Citizens Unleash Constitutional Challenge Against Kinder Morgan NEB Pipeline Review," Vancouver Observer, May 6, 2014. 
a breach of the rules of natural justice and left many feeling like there were questions that remained unanswered. Robyn Allan, an intervenor in the proceeding, said that "crossexamination gives NEB hearing participants the ability to spot inaccuracies, clarify contradictions, and assist the panel in making a competent decision in the public interest."77 In a submission to the hearing, Allan argues, "If the public believes, or has reason to believe, the NEB review process is biased in favour of the industry and unfair to the public interest because intervenors in this hearing are not able to fulfil their role, the public may no longer support the hearing process, or the National Energy Board as an institution." 78 The lack of cross-examination has never occurred before in a pipeline application of this kind. Instead, the NEB is using written information requests to test the evidence. In the Northern Gateway hearings, 90 days were used for cross-examination. No days were set aside for Kinder Morgan.

In an open letter to the NEB, Marc Eliesen, former CEO of BC Hydro, and former chair of Manitoba Hydro, with 40 years of experience in the energy sector, withdrew from participation in the process, calling it a sham and not in the public interest. ${ }^{79}$ In his letter, he condemns the lack of cross-examination and the inadequate response to information requests. There were over 2,000 questions asked of Kinder Morgan, only five per cent of which the Board required an answer from the company. Also, the Board denied requests for extensions to submit information requests by project opponents. Due to his concerns, Eliesen encouraged the province of British Columbia to withdraw from the NEB process and hold its own separate review panel. This reaction from a member of the energy industry is indicative of a process that is broken, or at least in jeopardy, and which is quickly losing credibility with the public.

Furthermore, requests from the cities of Vancouver and Burnaby for more information regarding emergency response plans for an oil spill were denied, compounding the doubts that this was a fair and open process. Vancouver Mayor Gregor Robertson told the CEO of Kinder Morgan that there is "a lack of public confidence in the NEB" and Mayor Derek Corrigan of Burnaby called the process "a sham." 80 The government of B.C. added controversy to proposed pipeline projects by amending the Parks Act to allow pipelines to go through provincial parks. ${ }^{81}$ The area on Burnaby Mountain is a city-owned conservation site that many value, and part of the route for the proposed pipeline expansion.

The City of Burnaby went to court to try to stop Kinder Morgan from doing survey work on Burnaby Mountain, but the injunction was denied. Because of that denial, protests led to over 100 arrests. ${ }^{82}$ When the court found out Kinder Morgan used wrong GIS co-ordinates for the injunction, all the charges were thrown out. ${ }^{83}$ All of these events have cast doubt on

\footnotetext{
See [204] A. Nikiforuk, “No Cross-Exam in Trans Mountain Hearing Hurts NEB Credibility: Economist,” The Tyee, April 23, 2014.

78 [5] R. Allan, "Notice of Motion," April 14, 2014.

79 [85] M. Eliesen, "Letter of Withdrawal," Oct. 30, 2014.

80 See [50] CBC News, “NEB CEO Peter Watson Heckled by Kinder Morgan Pipeline Protesters,” April 24, 2015.

81 The bill was passed March 24, 2014. See [171] Legislative Assembly of British Columbia. 2014. "Bill 4 - 2014: Park Amendment Act, 2014."

82 See [232] M. Prystupa and J. Uechi, "RCMP Responds with Respect as Grand Chief Arrested on Burnaby Mountain," Vancouver Observer, Nov. 27, 2014.

83 See [159] J. Keller, "Burnaby Mountain Protest Charges Dropped," Huffington Post, Nov. 27, 2014.
} 
the regulatory process. City mayors making claims that there is no public confidence in the $\mathrm{NEB}$, and that its process is a sham, followed by significant protests leading to arrests, are indicative of a regulatory process that is broken.

In 2012, omnibus bills C-38 (the Jobs, Growth and Long-Term Prosperity Act) and C-45 (the Jobs and Growth Act), were both passed with no public consultation, and limited debate in Parliament. These omnibus bills changed several acts. They repealed the Environmental Assessment Act and replaced it with the Environmental Assessment Act 2012; changes in the new act limit the definition of environmental effects to fisheries, marine animals in the Species at Risk Act, and migratory birds. The Fisheries Act now only protects habitat for Aboriginal recreation and commercial fisheries, but overall habitat protection is weakened. The Navigable Waters Protection Act exempts pipelines and power lines from its application. The NEB absorbs the Navigable Waters Protection Act when there is a pipeline or power line. The National Energy Board Act was changed to limit applications to an 18-month time frame. The fact that so many legislative changes could take place in two parliamentary bills, with little debate and no outside consultation, gives the impression that the government of Canada does not value consulting on processes, laws and policies.

The Mikisew Cree and Frog Lake First Nations challenged these omnibus bills, claiming that these changes that they introduced significantly affected protections for their traditional lands, which triggers a duty to consult with the affected First Nations. The Federal Court of Canada ruled in favour of the Mikisew Cree and Frog Lake First Nations, saying the federal government had a duty to consult with them. ${ }^{84}$ However, the court did not overrule the laws that were passed. It was an empty victory. Such cases leave the impression that while First Nations use the legal system to resolve situations peacefully, it does not bring the kind of remedies they need and want and they have to look at other avenues.

The B.C. government provided tax concessions (relative to previous announcements on the level of taxation) to liquefied natural gas (LNG) project proponents through Bill 26. ${ }^{85}$ The federal government in turn provided a tax break for LNG projects. The implication is that both levels of government are trying to incent LNG companies to make the final investment decision. The public can see that governments are pushing for large energy projects. This also contributes to the public thinking the regulatory process is broken, and the impression that governments will provide consent to projects no matter what.

\subsubsection{Crisis of Legitimacy?}

Is social licence reflective of a crisis of legitimacy in this country? It would seem to be so. Former Natural Resources minister Joe Oliver publicly stated that social licence was being used by a minority of opponents to block a project even after it had been approved and determined to be in the national interest. ${ }^{86}$ Oliver also publicly called opponents of

\footnotetext{
[188] Mikisew Cree First Nation v. Canada (Governor General in Council), 2014 FC 1244.

85 [116] Government of British Columbia, Ministry of Finance. March 25, 2015. "Commitment to Finalize LNG Income Tax Framework Fulfilled."

86 [95] J. Fekete, “'Minority’ using 'Social Licence' to Block Resource Projects, Joe Oliver says,” Ottawa Citizen, March 6, 2015.
} 
Canada's energy markets "radicals" with a radical ideological agenda that undermined the national economic interest. ${ }^{87}$ This called into question the government's ability and willingness to legitimize varying viewpoints on energy development. B.C. Premier Christy Clark and former Alberta premier Jim Prentice have said that social licence is needed for major projects like Northern Gateway. ${ }^{88}$ Such statements show that social licence is gaining momentum and credibility. The recognition by ministers and premiers that social licence is a going concern illustrates the crisis of legitimacy.

Raven Coal is a proposed project in Comox, B.C. that has been withdrawn in the face of public opposition. On its second attempt to get its application for a coal mine through the B.C. Environmental Assessment, it withdrew its application, citing misinformation in the involved communities. ${ }^{89}$ Opponents to the project commented that there was no social licence for Raven Coal..$^{90}$ Opposition was quite strong to this project, both in Comox, the mine site, and Port Alberni, B.C., the port from which the coal would be shipped. Raven Coal spent \$20 million as of March 2015 trying to get its application through and has walked away due to public opposition based on what it considers "misinformation." 91

In British Columbia, several proposed energy projects are in court due to challenges of the regulatory process or the consultation process with First Nations. For example, the proposed Site C dam, as of April 2015, had seven court cases against it. ${ }^{92}$ The Peace Valley Landowners Association challenged the validity of the environmental assessment process and lost in the B.C. Supreme Court. ${ }^{93}$ As well, the Treaty 8 First Nations challenged the validity of the environmental assessment process for the project and lack of proper consultation..$^{94}$ The B.C. Supreme Court dismissed the judicial review of the environmental assessment certificate, ${ }^{95}$ and the project appears to be going ahead and is under construction.

As mentioned previously, Enbridge's Northern Gateway project also has multiple court challenges against it and Kinder Morgan's Trans Mountain pipeline has been challenged before the final project decision has been reached. ${ }^{96}$ The amount of opposition that these projects are facing strongly suggests that they lack a social licence to proceed. Some of

[140] L. Herrmann, “Canadian Resources Minister Calls Enviros 'Radical Groups,,” Digital Journal, Jan. 11, 2012.

88 Ibid [95].

89 [54] Compliance Coal Corporation, Letter to B.C. Associate Deputy Minister of Environment, March 2, 2015.

90 [252] S. Stanfield, "Raven Coal Mine Application Withdrawn,” Comox Valley Record, March 4, 2015.

91 Ibid.

92 [274] J. Wakefield, "Site C Faces First Volley in Barrage of Legal Challenges," Alaska Highway News, April 20, 2015.

93 [40] Canadian News Wire, "PVLA Appeals B.C. Supreme Court Ruling on Site C and Strongly Endorses B.C. Auditor General Performance Audit of Site C," July 22, 2015.

94 [158] J. Keller, "First Nations Launch Federal Court Challenge of B.C.'s Site C Dam," Globe and Mail, Nov. 14, 2014.

95 [253] W. Stodalka, "Judge Closes One Door, Opens Another on Site C Legal Challenge," Victoria Times Colonist, Sept. 20, 2015.

96 See [199] National Energy Board, "Court Challenges..." 
these groups, such as Tsleil Waututh and Treaty 8, who are bringing court cases, are canvassing for donations to offset legal fees, and those who are opposing these projects are contributing to these funds in the hopes the projects will be stopped. ${ }^{97}$

In New Brunswick, clashes over hydraulic fracturing have been prevalent and the question of what social licence actually means has been raised in the legislature. ${ }^{98}$ Marches, protests and petitions have come from New Brunswickers as the pressure not to allow hydraulic fracturing was mounted by communities and environmental groups. ${ }^{99}$ The premier of New Brunswick and his government announced on Dec. 18, 2014 that they were placing a moratorium on hydraulic fracturing until five conditions were met: a social licence, a process to consult with First Nations, a plan for mitigating impacts on public infrastructure, a mechanism in place to maximize benefits for New Brunswick, and credible information about the impacts of fracking on health, water and the environment. ${ }^{100}$

In Newfoundland and Labrador, the opposition to hydraulic fracturing led the minister of Natural Resources to appoint an independent panel to look into its socio-economic and environmental effects. ${ }^{101}$ Finally, in the Northwest Territories, the government engaged in consultation on proposed regulation on hydraulic fracturing. Consultations ended in June 2015, and the government is expected to pass the regulations. ${ }^{102}$ Public consultation showed opposition to hydraulic fracturing from the public and First Nations, ${ }^{103}$ and the government of the Northwest Territories has subsequently committed to further discussion of the regulations. ${ }^{104}$

The issue of a crisis of legitimacy can be found in how the Crown treats First Nations' constitutionally protected rights and how the Crown carries out the duty to consult. A regulatory process cannot be considered legitimate if it overrides First Nations' rights and title. The courts have said that consultation can go through the regulatory process as long as "available regulatory processes are accessible, adequate and provide First Nations an opportunity to participate in a meaningful way." 105 In the Taku River Tlingit case, ${ }^{106}$ the courts decided that because the Taku had participated fully in the environmental assessment process, their views had been put forward and their concerns were addressed by the measures put in place in the medium and long terms. Because of this participation in the

97 See [236] Respecting Aboriginal Values and Environmental Needs, "Join the Circle - No Site C" and [243] Sacred Trust Initiative, "About Sacred Trust."

[229] J. Poitras, “'Social Licence’ Clouds Debates over Fracking, Pipelines,” CBC News, Dec. 22, 2014.

99 See [176] E. Lui, "A Trip to New Brunswick to Learn About Shale Gas Development and What Communities are Doing About it," Rabble, April 11, 2014, and [250] T. J. Skolnick, "Digging Deeper into New Brunswick's Fracking Controversy," The Tyee, Aug. 10, 2011.

100 [125] Government of New Brunswick, Office of the Premier, "Government Introduces Moratorium on Hydraulic Fracturing in New Brunswick," press release, Dec. 18, 2014.

101 [126] Newfoundland \& Labrador Ministry of Natural Resources, "Minister Announces Independent Panel for Review of Hydraulic Fracturing," press release, Oct. 10, 2014.

102 [273] A. Vivian, "Fracking in the NWT," The Lawyers Weekly, June 19, 2015.

103 [99] Fort Nelson First Nation Lands Department, "Dene Nation Speaks out on Proposed Controversial Regulations for Fracking: Multiple Presenters Stand in Line Late into Evening to Voice Concerns," June 17, 2015.

104 [127] Government of the Northwest Territories, "Discussions on Hydraulic Fracturing Regulations to Continue into 18th Legislative Assembly," Sept. 17, 2015.

105 [32] Brokenhead Ojibway Nation et al., v. A.G. (Can.), 2009 FC 484, para. 42.

106 [258] Taku River Tlingit First Nation v. British Columbia (Project Assessment Director), 2004 SCC 74. 
environmental review process, it was ruled that they did not need a consultation process in addition to the environmental assessment. The Tsleil-Waututh, in their federal appeal of the Trans Mountain pipeline, argued that their ability to appear for a short time before the NEB panel was not sufficient for consultation and accommodation. ${ }^{107}$ The eight First Nations who challenged the Northern Gateway project and the five First Nations who challenged the Site $\mathrm{C}$ dam are all examples of how affected First Nations respond to the crisis of legitimacy.

The increasing number of protests in various areas of Canada is also culminating in a crisis of legitimacy. When premiers and mayors demand that social licence be required before a project commences, it strongly suggests that the regulatory process's legitimacy is at stake.

\subsubsection{Democratic Elections are Insufficient Checks for the Regulatory Process}

Can the public rely on electing representatives to Parliament or their legislatures to provide for sufficient checks in the regulatory process? This is a question that should be more fully explored beyond this white paper; we do know that the election process happens approximately every four years and it is too slow or infrequent to be an immediate check on the regulatory process. While election platforms may provide some information on the party's proposed direction on energy and the environment, voters do not know the detailed agenda that the party will actually undertake on the environment, GHG reductions, climate change, and their opinions on specific energy projects. For instance, the Conservative Party of Canada condemned the use of omnibus bills by the Liberals during their 2006 election campaign, and since used them to do wholescale changes to multiple acts at a time.

While a particular MP or MLA may have the environment's best interests at heart, the majority of the time party policy will dictate how they vote. When people in B.C. voted in the Liberal party, they did not know that the government's subsequent actions would allow pipelines through parks (via Bill 4, Park Amendment Act) or remove the B.C. Utilities Commission's oversight on major projects like Site C, Northwest Transmission Line and upgrades to the Mica and Revelstoke dams (via Bill 17, Clean Energy Act).

In addition, as circumstances change in the provinces or federally, the party in power may change its election promises or deal with an issue in a way that could never have been predicted. In very rare circumstances, people are elected or not elected based on their positions on such energy or environment issues as hydraulic fracturing. ${ }^{108}$

\subsubsection{The Current Regulatory Process has not Adapted to Accommodate Changes in Societal and Technological Realities}

Today's societies are very concerned about the cumulative effects of overall development, greenhouse gas emissions, and in particular, climate change. As the world experiences global warming, shrinking ice packs, warming waters and severe weather events, climate change is becoming more important to Canadians. One major issue with the current federal

\footnotetext{
107 See [199] National Energy Board, "Court Challenges ..."

108 [175] N. Logan, “N.B. Election: Did Shale Gas and Fracking Sway the Vote?”, Global News, Sept. 23, 2014.
} 
regulatory process is that there is no opportunity for review of the impacts of developments on climate change, or of cumulative effects, both of which are critical for preparing for more developments in the future. ${ }^{109}$ Another key issue is that the current national energy strategy is insufficient to address these problems.

Technology has made it easier to oppose projects in a greater way and has added to the power of social licence. Social media gets the message out immediately, information is easier to access than it has ever been, and more people can be reached in a quicker time period. On the day that the Northern Gateway project was approved, a message went out to flood the streets with people to show continued opposition to it. ${ }^{110} \mathrm{Blogs}$, websites, Facebook, Twitter, Instagram, Tumblr and many other methods provide people with information on projects as well.

The questions that began this section require more analysis as to what criteria should be used in determining if a regulatory process is broken. The indicators that were explored show that they could be used to show that the regulatory system is broken or, at the very least, is in jeopardy and close to being broken. This will change with various parties involved. The provincial or federal government will be the last to figure out that the process is broken and needs to be changed to meet the general public's values. First Nations, and environmental and other groups may believe the processes are broken and are the ones challenging the process in court or on the ground.

\subsection{Case: The Regulatory Process is Not Broken}

The research discussed in section 3 provides various analyses of what the term "social licence" means. Although there are different perspectives, there seems to be consensus that legitimacy and trust in the decision-making process, including the regulatory process, are key to social acceptance of major projects.

The question remains, however, who decides? Who must accept a project before it can proceed? How many members of the public must say so? If a majority of the public trusts the regulatory process, believing it to be legitimate, is that sufficient? Is it still sufficient if a vocal minority says otherwise? From where do the members of a vocal minority derive their legitimacy? How do decision-makers react — and how should they react — in the face of public protest, even if the then-current regulatory process is followed?

Much of the discussion assumes that because of protests, media coverage and other negative commentary, certain major projects have not achieved the necessary social licence or social acceptance. Northern Gateway, the proposed pipeline project from Alberta to the Pacific Coast, is an example. It received approval by the Joint Review Panel of the National Energy Board/Ministry of the Environment, but after over four years of study and hearings, the approval was conditional on the project meeting 209 specific conditions. This was no rubber stamp. However, notwithstanding such approval and the stringency of

\footnotetext{
109 The issue of cumulative effects is also related to the issue of jurisdiction. In the case of federal regulatory processes, concern over upstream developments is difficult to appropriately address as these are regulated at the provincial level.

110 [10] I. Bailey, “'The war is on': Protesters Set Sights on Harper After Northern Gateway Decision,” Globe and Mail, June $18,2014$.
} 
the conditions, certain national politicians have said they would prevent the project from being built, citing lack of social licence. The regulatory process for TransCanada's Energy East project, a proposed pipeline to carry oil to the East Coast, has only just begun, but again, some politicians are already saying no. Before even giving the established regulatory process a chance, they are already claiming that the project does not have the necessary social licence. ${ }^{11}$

Section 3 of this paper attempts to define the concept of social licence or social acceptance, who grants it, with what legitimacy, and whether it exists with respect to any particular project or process. The bigger question, then, is what do those conclusions (or the lack thereof) mean for decision-makers with respect to such projects or processes?

Do public protests, leading to delays or cancellations of projects notwithstanding compliance with the regulatory process, mean that the regulatory process is broken? In this section of the report, we suggest that the system is not broken - capable of improvement, yes - but not broken. On the contrary, we argue that the system that we have would be broken if, in reaction to special interests or what could be a vocal minority, political decision-makers usurp, override or ignore decisions made by our established regulatory process, in the absence of clear evidence of public opinion by way of an election or a referendum.

\subsubsection{The Regulatory Process}

Our regulatory system is not a singular or static thing. It encompasses the variety of regulatory processes that Canada (at the federal, provincial, territorial and municipal levels) has implemented and refined, over many years. These must be undertaken and complied with before virtually any type of project can proceed. These laws and regulatory processes have been developed in order to promote and protect the local, regional or national (as applicable) public interest, from economic, environmental and security perspectives - often changed by legislators in response to public input.

In Canada, anyone proposing to build virtually anything — a road, a railway, a housing development, a pipeline, a well for water, a mine, an airport, a subway station, a factory, a hospital, a dairy farm - must obtain regulatory approval to proceed. Such approval requires compliance with environmental assessment legislation (federal and/or provincial and/or municipal), and a host of other rules and regulations that may include zoning bylaws, noise regulations, and other requirements specific to the proposed activity and location.

Some decisions that are needed for the benefit of the larger good may still have certain negative consequences. Our regulatory tribunals need to take into consideration environmental effects, Aboriginal rights, and local and community preferences, but they must balance those with what is in the larger public interest. They make recommendations based on a review of scientific and technical information placed on the record by both proponents and objectors; they make recommendations based on the evidence provided, within the legal framework enacted by Parliament and applied by the courts.

111 See: [209] D. O’Keefe, “Energy East Lacks Social Licence: Trudeau,” Ricochet, Dec. 15, 2014, and [210] P. O’Neil, “Tom Mulcair Fights the Squeeze in Metro Vancouver Ridings," The Vancouver Sun, March 17, 2015. 
Most applications, for all sorts of projects, proceed uneventfully. The regulatory process results in recommendations to proceed, to not proceed, or to proceed provided a number of conditions are met, and appeal processes are provided and complied with. By far, the majority of these decisions are made with no, or very little, public protest, and projects are either denied or built based on the scientific and other evidence gathered for the purpose. This includes evidence presented via public hearings, all of which is then analyzed by the regulatory bodies involved. ${ }^{112}$

Our overall regulatory system is not broken; indeed, it functions well most of the time.

\subsubsection{The Challenges}

There are, however, some exceptions. They may be small in number, but large in terms of project size, level of public protest and/or media attention. The challenges faced by these projects have prompted this discussion.

But where exactly does the problem lie?

(i) Is it when a regulatory body reaches a decision or makes a recommendation, having fulfilled its legislative mandate and complied with the rules set out for the process (a decision), there is some public protest, but the proponents and political decision-makers still proceed according to the decision?

(ii) Is it when a regulatory body reaches a decision, there is some public protest, and because of the protest the proponents choose not to proceed with the project? This may suit the protesters' wishes, but if any of these projects would have been in the larger public interest, has the process that resulted in a decision not to proceed somehow failed the public it is supposed to serve?

(iii) Is it where a regulatory body reaches a decision, there is some public protest, and although the proponents are willing to proceed, political decision-makers refuse to implement the decision or otherwise publicly deny its legitimacy? As above, this may suit the wishes of those who disagree with the project, but the political decision-makers have an obligation to make decisions in the larger public interest, and for the larger public good. In this case, one could argue that the system has failed, if the cancelled project would indeed have been in the larger public interest, then the public interest is the loser.

In every case, the fundamental question must be, which should be given precedence, (i) the results of a comprehensive, legislatively mandated and rules-driven regulatory process, established and evolved through our democratic processes to serve the public interest (and for large infrastructure projects, the larger, national public good); or (ii) protests, by relatively undefined, unidentified ${ }^{113}$ and unelected people and groups?

112 For example, the original Keystone pipeline had 30 intervenors and six commenters, and the Enbridge Line 9 Reversal Phase I hearing had 18 intervenors and 145 commenters.

113 This piece assumes that Aboriginal groups are in a position to pursue treaty and other rights, as they already exist and are being increasingly well-defined and quantified, and that those legal rights do not form part of the more nebulous "social licence." 
The answer, in a democratic society such as ours, must be the process. Yes, it can and should be improved - it has been, and will continue to be, very much as a result of public input - but it must be what we rely on until such improvements are made. Otherwise, political decision-makers' power is no longer constrained by our rule of law, something that is fundamental to a democracy.

\subsubsection{Trust and Legitimacy}

The whole system is based on the fundamental social contract between the public and government, well-described in section 3 of this paper as the recognition that society is built upon an unwritten acceptance by the public to be subject to a set of rules. Fundamental to this social contract, however, is the public's trust in government, which can only exist if the public believes in the relevant government's legitimacy.

Do the public protests, media coverage and negative commentary with respect to certain projects and certain aspects of the regulatory process suggest that the public has lost that required level of trust and that belief in the system's legitimacy? The critical piece here is that we don't know. The only way, in our democratic system, to know this for sure is by way of an election or a referendum. Absent that, the level of dissent is impossible to measure. Terms such as "public opinion," "environmental groups," "opinion leaders," "stakeholders," "civil society" and "community" are repeatedly used, but how are they defined? How are they measured? How is support measured versus opposition? Polls are conducted from time to time, but they are fraught with difficulty, including the purposes of the polls, the questions asked, and who is being polled. Small numbers of protesters may represent the majority of public opinion, but the opposite may be true - they may also represent only a small minority, with the silent majority supporting a particular project or process. We simply don't know. That's why we have developed the regulatory processes we have.

\subsubsection{The Evolution of the Regulatory System in Our Democratic Society}

There are, and will almost always be, people who do not agree with certain decisions, or with the processes by which those decisions were arrived at. But policy-makers, law-makers and other decision-makers must remember that their responsibility is to the larger public interest, to the larger public good, not to those who may be most vocal or those who get the most media coverage. Certainly, protests, commentary and open discussion can, should and do inform those law-makers. Part of how the system works, and how it has evolved and improved over time, is that those law-makers respond to what they see as changes in public opinion by changing laws and amending regulatory processes. Sometimes, it can be slow, and it may not be perfect, but it is how our democracy works.

Indeed, over the course of Canadian history, thanks to democratically elected officials at all levels of government, legislation and regulatory processes have evolved, keeping pace (more or less) with evolving public perceptions. They have become increasingly comprehensive, more attuned to environmental, labour and other socio-economic concerns. They continue to evolve in this way, as the notion of what comprises the public interest also 
evolves, and as elected politicians react to those changes in opinion through the process of changing legislation. Although the details of a particular regulatory approach can always be improved, in general, this evolving process is how the required level of trust and sense of legitimacy is maintained.

\subsubsection{The Importance, in a Democracy, of Adhering to the Regulatory Process}

We argue here that, rather than increasing a sense of trust and legitimacy, usurping this process in reaction to protests — or in reaction solely to any special interest group(s), whether business, provincial governments, municipal representatives, environmental NGOs, or any other interested stakeholder(s) — does the opposite. Allowing political decision-makers to usurp the end result of the process, in effect allows them what amounts to veto power over those we have entrusted with a process that is in the larger public interest. This approach is more than just problematic, it borders on anarchy.

There is no question that legitimate environmental and other concerns need to be heard — and addressed — before large infrastructure projects are able to proceed. And despite some progress, settling Aboriginal land claims and establishing mutual understanding and agreement for the future must happen; yet, it is taking far too long.

Fortunately in Canada, people have the right to protest peacefully, without fear of being harmed. They have the right to lobby for changes in policy. They have the right to work for a change in government to one that they believe better respects their concerns, such as environmental sustainability and Aboriginal rights. But do they have the right to ignore or usurp decisions that have been arrived at through our democratically elected and developed process?

No.

We elect our politicians, and although the results never please everyone, it is a pretty good system. The politicians we elect pass laws - again, not to everyone's satisfaction, but that is the job with which our system entrusts them. Those laws create the rules and regulations that in turn establish, (often over the course of multiple governments and different political parties) our regulatory bodies and processes that we rely on to analyze, review, deny or approve things like big infrastructure projects.

Those politicians and other decision-makers who now use the term "social licence" to question those decisions may have good intentions. They may just be angling for votes. Either way, however, they are undermining — indeed, subverting — the processes that have evolved over many years in the very system that gave them their jobs. They should be encouraged to revise the processes as they deem necessary, but they must not be able to ignore them in the meantime. 


\subsubsection{Practical Reality - The System can be Improved}

The practical reality, however, is that we now face what appears to be growing public protest (or what seems to be more vocal and more widespread through social media) over certain projects and certain regulatory decisions. Some commentators, including some heavily involved in the regulatory process itself acknowledge that not all of our regulatory processes are the same, nor equally effective. ${ }^{114}$ Some have better outcomes than others, both (i) in the decisions being made in the best interest of the public versus special-interest stakeholders, and (ii) in the acceptance of the decisions by those who feel that the process was not sufficiently transparent or that they were excluded from meaningful participation. "Strategic regulatory processes can be designed to produce good outcomes. However, they can also result in a free-for-all where the public interest gets sacrificed for the interests of the politically influential." 115 Lack of transparency is particularly problematic. And when parties feel excluded from the official process, they can and do resort to public protest, negative social media messaging, and even civil disobedience. Proponents will hesitate to proceed and politicians will sway toward what they perceive is vote-worthy rather than evidentiary, and projects that might otherwise be in the public interest are significantly delayed or stopped altogether.

The answer is not to replace undue influence of some interests with undue influence of others. "In the long run, it is in no one's interest, even the currently politically influential, to have weak processes for formulating decisions. We need to enlist all stakeholders, including business and civil society, to build broad support for regulatory processes that have integrity..." [26]. ${ }^{116}$

Should we insist that the regulatory process we have be followed, even if not perfect? As a democracy, yes. But can the regulatory process be improved in a way that legitimate concerns are more thoroughly addressed, and the process improved in ways that will increase the level of trust in the results, thus reducing public protest?

Yes, as well.

\subsection{Case: The Regulatory Process Is Not Broken, but Should Be Improved}

The regulatory process is complex and working to accommodate social acceptance is a challenging process. As noted earlier in this paper, the regulatory process must address three key dimensions that include the efficiency and competitiveness of markets, energy security and environmental impacts. Striking the appropriate balance among these factors is critical. Further complicating goals aimed at reforming the regulatory process is the mix of regulatory processes provincially and federally and the balance of control over energy resources and trade in energy resources between the provinces and federal government.

\footnotetext{
114 Paul Boothe, former deputy minister, Environment Canada, has some insightful thoughts on what constitutes good regulation in [26] P. Boothe, "Making Good Regulations," Canadian Public Policy, 39(3), 2013, 359-370.

115 Ibid, 361.

116 Note: Boothe's paper includes a description, from his experience at Environment Canada, of what he refers to as the five characteristics of world-class regulation: (i) evidence-based decision-making; (ii) effectiveness; (iii) efficiency; (iv) transparency; (v) adaptability.
} 
Social licence is a contested concept and, earlier in the paper, various versions of this concept were discussed including the pyramid model, the three-strand model, and the triangle model. This section highlights how public acceptance can be better addressed in energy project development.

\subsubsection{Federal-Provincial Collaboration to Standardize Regulation}

Greater collaboration between federal and provincial regulatory bodies has been highlighted as necessary in creating confidence in the energy development sector. At the 2013 Council of the Federation meeting, delegates discussed the need for more transparency and collaboration, noting the importance of seeking intergovernmental collaboration in efforts to optimize the strengths and opportunities for each province and territory with respect to energy development. Areas of potential collaboration included new technologies, energy conservation and energy resources. Underpinning the potential to realize the benefits of greater collaboration among federal, provincial and territorial jurisdictions was overall greater alignment of the regulatory process.

Greater alignment between the federal and provincial regulatory processes, including a shift toward "one project, one review" for major resource projects, is critical in advancing regulatory efforts. ${ }^{117}$ Regulatory reform of this nature would enhance project certainty, reduce risk and provide efficiency for the energy sector and government regulators. Movement in this direction would create a greater environment for business investment and improve the national economy [89]. Regulatory reform of this nature does not imply a relaxation of socio-economic and environmental goals and objectives for the energy industry but rather considers how energy development can proceed, and become less regulatorily burdensome, without provinces, territories and other stakeholders forfeiting environmental and socio-economic objectives.

Further federal, provincial and territorial government collaborative efforts with respect to energy development include: ${ }^{118}$

- Implementing an early warning system to proactively flag significant issues that may arise during the review of a major resource project;

- Applying Aboriginal consultation mechanisms to improve federal-provincial coordination of consultation processes and issue resolution;

- Developing harmonized federal-provincial project agreements to improve alignment of federal and provincial review processes;

- Mapping federal and provincial project review processes to demonstrate areas of alignment and to facilitate substitution and equivalency;

- Implementing alignment mechanisms through pilot projects.

Recommendations for reforms to the regulatory process fall under six key categories, and include eliminating uncertainty in the regulatory process, shortening project review

117 [200] Natural Resources Canada, "Canada's Annual Energy and Mines Ministers' Conference — Energy."

118 [88] Energy and Mines Ministers' Conference, “Toward Greater Pan-Canadian Collaboration: A Progress Report,” 2012. 
timelines, developing mechanisms for balancing risk, increasing transparency, limiting joint review panels, and clarifying Aboriginal consultation. ${ }^{119}$

At the 2013 Council of the Federation meeting, premiers of the provinces and territories discussed energy security and stability. A key issue discussed was the need for greater transparency in the regulatory process that would support more responsible energy development. A more vigorous environment management regime coupled with greater transparency would effectively ensure a secure energy supply to Canadians and allow for "non-discriminatory transportation and transmission of energy resources." 120

Additional mechanisms and processes to further support greater federal and provincial collaboration related to energy development can include a regional planning-based regulatory approach. This approach would involve multiple stakeholders and a crosssectoral approach to regulating energy development. A regional planning-based regulatory approach would also cut across different municipalities but have these municipalities cooperating. Other suggestions for federal and provincial collaboration include:

- An energy forum to create greater collaboration and dialogue between federal and provincial leaders. This forum would be developed so as to avoid political grandstanding;

- A national energy strategy where projects are considered in the context of a national strategy and not as one-offs. This strategy could include common understanding as to how we are developing energy resources.

Efforts toward greater federal-provincial regulatory collaboration are an ongoing concern and may reduce risk and uncertainty and build investor confidence. These efforts may also build stakeholder confidence, as central to many of these discussions is the importance of transparency and a more rigorous environmental review.

\subsubsection{Trust}

Building trust in the regulatory process requires regulators and energy developers to be mindful of their motivations for consulting stakeholders. The following section highlights key issues in engaging stakeholders that regulators and developers should rethink with respect to energy development and regulatory reform.

Trust is a core issue that deeply influences the level of faith in the regulatory process with respect to energy development. Trust in government and regulatory processes have historically diminished due to past projects and the way in which they were approved [67]. Because of this history, many stakeholders (e.g., land owners, First Nations, etc.) are strongly influenced by, and have become more risk averse in regards to, development projects that might affect them. Acknowledging past mistakes and offering apologies are considered necessary to rebuilding trust. More important, however, is not repeating the same mistakes but changing how projects proceed in the future.

119 Ibid.

${ }^{120}$ [58] Council of the Federation, “Canadian Energy Strategy: Progress Report to the Council of the Federation,” July 2013. 
Informing stakeholders of energy projects and involving them in discussions of their potential impacts at the earliest stages in project development is critical to building trust. Doing so may not always lead to project approval by stakeholders, and in many cases might only provide a level of community and stakeholder tolerance for a project $[67,286]$. Lack of project approval may not always imply that the project has been rejected.

Table 7 highlights the key themes in stakeholder engagement in the literature with respect to renewable energy projects. Lessons can be drawn from these examples across the energy development sector.

\section{TABLE 7 KEY THEMES IN STAKEHOLDER ENGAGEMENT}

\begin{tabular}{|c|c|c|}
\hline Theme & Description & Source \\
\hline Acceptance & $\begin{array}{l}\text { Primary goal of consultation: achieve local acceptance. Can and will vary } \\
\text { at different levels; e.g., society may believe in renewables but market may } \\
\text { not support them. Broad socio-political support for alternative energy may } \\
\text { coexist with local resistance to a given project. }\end{array}$ & $\begin{array}{l}\text { [291] Wustenhagen et al. (2007) } \\
\text { [67] Delvaux et al. (2013) }\end{array}$ \\
\hline $\begin{array}{l}\text { Relationship Building/ } \\
\text { Early Contact }\end{array}$ & $\begin{array}{l}\text { Consultation should begin as early as possible in the planning stages. } \\
\text { Fosters trust and communication. Allows local concerns and views to } \\
\text { be taken into account early on. Allows for protocols to be established } \\
\text { regarding what and when information should be shared. }\end{array}$ & [67] Delvaux et al. (2013) \\
\hline Trust & $\begin{array}{l}\text { Absolutely necessary to successful project implementation. Naturally } \\
\text { builds very slowly. Can be lost very quickly. }\end{array}$ & $\begin{array}{l}\text { [79] Dorian et al. (2006) } \\
\text { [291] Wustenhagen et al. (2007) } \\
\text { [237] Ricci et al. (2010) } \\
\text { [1] Adams et al. (2011) }\end{array}$ \\
\hline $\begin{array}{l}\text { Environmental, Noise } \\
\text { and Visual Impacts }\end{array}$ & $\begin{array}{l}\text { Impacts on audio-visual land- or seascapes or environment can cause } \\
\text { opposition. Result of place attachment. Renewables can be seen either } \\
\text { to fit in the landscape or not. Fit influences perception as benefit or } \\
\text { detriment. }\end{array}$ & $\begin{array}{l}\text { [291] Wustenhagen et al. (2007) } \\
\text { [259] Tarr (2012) } \\
\text { [286] Wiersma and Devine-Wright (2014) }\end{array}$ \\
\hline $\begin{array}{l}\text { Community Benefits } \\
\text { or (Co-) Ownership }\end{array}$ & $\begin{array}{l}\text { Direct benefits a key factor in achieving acceptance of a project. Local } \\
\text { (co-)ownership, payments or lowered energy prices as possible methods } \\
\text { to create these benefits. Many projects still developing novel models to } \\
\text { attempt benefit-sharing. }\end{array}$ & $\begin{array}{c}\text { [65] del Rio and Burgillo (2009) } \\
\text { [1] Adams et al. (2011) } \\
\text { [259] Tarr (2012) } \\
\text { [67] Delvaux et al (2013) [286] Wiersma and } \\
\text { Devine-Wright (2014) }\end{array}$ \\
\hline $\begin{array}{l}\text { Equitable and Just } \\
\text { Decision-Making }\end{array}$ & $\begin{array}{l}\text { Major concerns exist over the fairness of decision-making regarding } \\
\text { renewables siting. Exacerbated when developers not local. Participatory } \\
\text { processes a method of achieving equity. }\end{array}$ & $\begin{array}{r}\text { [65] del Rio and Burgillo (2009) } \\
\text { [237] Ricci et al. (2010) } \\
\text { [1] Adams et al. (2011) } \\
\text { [259] Tarr (2012) } \\
\text { [286] Wiersma and Devine-Wright (2014) }\end{array}$ \\
\hline $\begin{array}{l}\text { Information Sharing/ } \\
\text { Capacity Building }\end{array}$ & Accessible and easily understood information vital. & $\begin{array}{l}\text { [237] Ricci et al. (2010) } \\
\text { [67] Delvaux et al. (2013) }\end{array}$ \\
\hline $\begin{array}{l}\text { Endogenous Devel- } \\
\text { opment }\end{array}$ & $\begin{array}{l}\text { Reliance on local resources, workers and people. Incorporation of local } \\
\text { beliefs and priorities in planning. }\end{array}$ & $\begin{array}{l}\text { [65] del Rio and Burgillo (2009) } \\
\text { [259] Tarr (2012) } \\
\text { [67] Delvaux et al. (2013) }\end{array}$ \\
\hline
\end{tabular}

\subsubsection{Information Sharing and Capacity Building}

Stakeholder capacity building is increasingly viewed as a key factor in public consultation processes. Capacity building can:

- Provide a common base of knowledge for stakeholder participation;

- Provide skills and knowledge to participate effectively;

- Combat misperceptions stakeholders may have about a project;

- Enhance local capacity to improve community beyond project. 
Capacity building by creating more awareness and increasing knowledge is essential, as it serves to develop ongoing and long-term relationships among stakeholders, project components and regulators [237]. Building capacity requires a real commitment from developers and regulators as engaging stakeholders in this manner often requires significant time (and often resources) in order to develop the necessary skills among stakeholders to participate in the regulatory process. Developing research skills is an essential aspect of this capacity building as it allows stakeholders to review and understand the many reports associated with most development projects.

Supporting stakeholder capacity to participate in the regulatory process can involve other factors as well. Stakeholders who have early access to relevant data regarding energy development projects can contribute more effectively to discussions. In cases where stakeholders have budgetary limitations that could preclude their participation, funds should be made available to cover related travel costs. In the Strategic Environmental Assessment (SEA) of the Bay of Fundy for Tidal Energy Development in Nova Scotia, funds were set aside by the Offshore Energy Research Association (OERA) to cover travel and research costs related to stakeholder participation in the SEA process.

In some cases, stakeholders may fail to understand aspects of the energy development project. In this case, it would be necessary to provide non-jargon translations and explanations about the technical aspects of the proposed project. Education training sessions open to the public or a group of select stakeholders may be one venue for providing this education and can also address other issues that might include education on the processes related to extracting energy from different environments.

\subsubsection{Relationship Building/Early Contact}

Relationship building is key to building trust in the regulatory process. It should occur at the earliest stages of a project and be at the forefront of any strategy seeking to work toward a social licence [67]. Regulatory and energy development processes mindful of relationship building with relevant stakeholders are important aspects of developing a social licence. Local communities and relevant stakeholders may then perceive the regulatory process as a more collaborative approach, as opposed to an adversarial process. Furthermore, relationship building fosters other factors essential in working toward a social licence. For example, relationship building based on early disclosure of projects and education about the regulatory process and how energy is extracted, are ways in which trust can be built. Fostering trust through relationship building can be critical as projects move from the planning to implementation stages. Also, as new energy development initiatives arise, stakeholders are more likely to see their participation as meaningful if relationships have been developed.

\subsubsection{Summary}

There is the perception that the regulatory process is broken. What makes the regulatory process more burdensome is that many stakeholders choose to use the regulatory process to engage in larger policy debates despite the fact that at times the issues raised fall outside regulatory purview. This phenomenon bogs down the regulatory process and gives the 
perception that the process is broken. While the regulatory process may not be broken, there is indication that many stakeholders feel there is no space for the public to engage in debate on policy issues. Therefore, the regulatory process becomes in many respects the de facto venue for airing concerns on a broad range of related and unrelated topics with respect to a specific energy project. An example of this would be the issue of climate change. This issue has been imposed on local regulatory processes, as there is no other venue for discussion of these larger societal issues.

While there is the perception that the regulatory process is broken, there are certainly challenges with respect to the political dimension in that often, federal or provincial politicians interfere in the regulatory process. Research should be conducted on metrics indicating where decisions were made through a regulatory process and how the political process and politicians then influenced these decisions. It should be noted that political processes beyond the regulatory process are common and that trying to isolate regulatory decisions from the political process might prove unrealistic.

If regulatory processes were reformed to enhance and support social licence, identifying aspects that build trust, legitimacy and credibility with the multiple stakeholders would be a critical component to address. In addition, regulatory reform should be approached that is mindful of creating space, if necessary, to engage in broader issues that relate to energy development, given few venues exist for stakeholders to voice these larger concerns. However, balancing these larger issues with the more immediate concerns related to an energy development approval process might prove difficult and unwieldy in the end and may bog down the regulatory process. Finally, removing the political process from the regulatory process may prove difficult, given our current political system. While developing research metrics that indicate to what extent political interference-altered regulatory decisions might help, it is unlikely that we can look forward to a regulatory process free of the political process.

\subsubsection{Alternative Regulatory Approaches}

Regulatory processes vary among federal and provincial jurisdictions. While streamlining regulatory processes based on similar projects might be one alternative, this can prove very difficult as well, given that no two projects are alike. While command-and-control characterizes traditional approaches to regulation, alternative approaches to energy regulation have been explored. Nymark and Edge explore regulatory reform through an extensive literature review and have identified 10 principles to support regulatory reform [208].

1. Regulatory reform programs must be broad in scope and a priority at the highest levels of government.

2. Regulation should be results-oriented, effective, and respond quickly to new issues and emerging concerns.

3. Regulation must be cost-efficient.

4. Regulators should take into account potential risks and their possible impacts. 
5. Regulation must avoid duplication and inconsistency.

6. Regulation should be co-ordinated at the international level.

7. Regulation must be transparent and involve meaningful input from relevant stakeholders.

8. Regulations need to be regularly and systematically reviewed.

9. There must be an adequate number of regulatory staff with sufficient training and expertise.

10. The choice of regulatory instrument is critical.

In order for Canada to remain competitive, it is apparent that attention should be paid to these principles with respect to regulatory reform [208]. A well-developed public consultation process within the regulatory framework can build trust and support among the relevant stakeholders and work to support the legitimacy of the process, thereby increasing social acceptance of a project. Specific recommendations to support regulatory reform with respect to energy development projects include full-cost accounting and strategic and regional environmental assessment approaches.

\subsubsection{Full-Cost Accounting}

A lack of understanding of the true costs and benefits of energy development projects is often stakeholders' primary concern. Regulatory processes that incorporate fullcost accounting where the social, environmental and economic costs and benefits are determined through third-party verification may provide an alternative regulatory approach [228]. This approach may provide a mechanism as well for addressing broader issues such as climate change impacts. On a smaller scale, local externalities can be addressed through this process as well. Full-cost accounting addresses the broader issue of sustainability, given its likeness to the concept of triple-bottom-line [247].

\subsubsection{Strategic Environmental Assessments}

Strategic environmental assessments (SEAs) provide an option for addressing broader regional issues that might emerge in energy development projects. SEAs are viewed as a mechanism to shift the regulatory approach from policy-making to policy application [166]. The SEA is "intended to ensure positive contributions to sustainability, as well as mitigation of adverse environmental effects; to enhance the openness and credibility of strategic level decision-making; to provide earlier, clearer and more reliable guidance for the planning and approval of particular projects and other subsequent undertakings; and to improve the overall efficiency and fairness as well as the effective quality of decisionmaking" [110]. The province of Nova Scotia used the SEA process to guide the development of the regulatory process with respect to tidal energy development [212]. 


\subsubsection{Other Alternative Methods}

Other alternatives to energy development regulation include self-regulation [139]. This approach offers greater flexibility and adaptability to changing circumstances. Supporting this process might be the development of industry codes of practice, industry-based accreditation, and voluntary adoption of industry standards [139]. In the context of energy development and issues related to social acceptance, this might prove an unpopular approach unless significant monitoring and punitive measures are put in place. Perhaps companies with a proven track record and an internal monitoring system could have their projects fast-tracked through a self-regulatory process.

Other suggestions for alternative regulatory frameworks include developing regulations and limitations (similar to posting a speed limit) that offer proactive limitations on energy project development. Also, review times could be cut for projects where a similar type has already been approved. Reframing regulatory processes based on the size and classification of the energy project might prove useful as well. The Council of the Federation addressed how regulatory processes can be improved and support social licence by enhancing citizens', stakeholders' and investors' understanding of the approaches to developing energy in an environmentally sustainable manner. ${ }^{121}$

Ultimately, government and industry must review the current regulatory frameworks supporting energy development and determine what changes, if any, are necessary to address the growing discourse on social licence and energy development in Canada. Any alternative approach to energy development regulation requiring less public participation is, however, unrealistic as benefits gained in this regard would likely increase costs in other areas [139].

\subsubsection{Outreach and Regulation}

Supporting legitimacy and credibility of energy development projects and overall efforts towards social acceptance requires public consultation processes that are initiated early in the development process and that are ongoing through the entire phase of a project. In most instances, stakeholders are consulted in order to get buy-in for a project, but once this occurs, ongoing stakeholder consultation is limited. Budgets for stakeholder and community consultation typically reflect this pattern as well. Prior to stakeholder and public outreach, it is important to identify the relevant stakeholders.

\subsubsection{Stakeholder Identification}

A critical factor in developing public participation processes is stakeholder identification. With respect to energy development projects or most large industrial projects, identifying stakeholders can be difficult. Regulators are placed in a difficult position because they need to determine whether a body has standing and how much weight should be given to that person's or group's position in terms of influence on the decision. Can anyone become a stakeholder who has an opinion on an energy project? Or should stakeholders be only those

121 [58] Council of the Federation, “Canadian Energy Strategy: Progress Report...," July 2013. 
directly affected by the project? Questions to consider in identifying stakeholders include: ${ }^{122}$

- Who is investing in the development?

- Who will the development affect, either positively or negatively?

- What are the changes the development will bring and who supports or opposes such changes?

- What are the official posts in the area of the development and who holds them?

- Who is influential in the local community?

- Who are the representatives of local organizations with environmental or social interests?

- Who are the representatives of local organizations with economic interests?

- Who are the representatives of similar (if any) developments in the area, such as existing offshore wind farms?

- Was there anybody involved in similar issues in the past?

- Who are the local policy-makers?

- Who are the representatives of the local/regional research community?

- Who else should be involved?

Impact zoning might be a useful mechanism to identify stakeholders as well [189]. This process has the project proponent identifying the broad project components and assessing their likely social and environmental impacts. These are then mapped. Once the impacts and zones are identified as well as key stakeholder groups, then overlaying these groups over the impact zones provides insight into who is impacted and to what extent. This process has proven successful in identifying stakeholders and their key concerns early in the development process.

\subsubsection{Methods for Engaging Stakeholders}

Building trust, legitimacy and credibility requires careful planning of the public consultation process. Key issues to consider are the extent of control developers and regulators have over the consultation process and to what degree this influences the direction of communication, the tone and topics of discussion [237]. The following table highlights traditional methods for stakeholder consultation that take these issues into consideration. 


\section{TABLE 8 STAKEHOLDER CONSULTATION METHODS (TRADITIONAL)}

\begin{tabular}{|c|c|c|c|c|}
\hline Method & Description & Directionality & Public Input & Source \\
\hline $\begin{array}{l}\text { Public Exhibition } \\
\text { (Information Sessions, } \\
\text { Roadshows, etc.) }\end{array}$ & $\begin{array}{l}\text { Proponent organizes a display or presen- } \\
\text { tation about the project, in a community } \\
\text { space, and answers questions from the } \\
\text { attending public. }\end{array}$ & $\begin{array}{l}\text { Primarily unidirectional; } \\
\text { sometimes limited } \\
\text { bidirectional feedback. }\end{array}$ & Usually low & $\begin{array}{c}\text { [242] Royal (2008) } \\
\text { [14] Barnett et al. (2012) }\end{array}$ \\
\hline Workshops & $\begin{array}{l}\text { Proponent and local stakeholders meet } \\
\text { to discuss project plans, details, and } \\
\text { possible approaches/improvements in } \\
\text { depth. Early phase process. }\end{array}$ & $\begin{array}{l}\text { Bidirectional; } \\
\text { dialogue between proponents, } \\
\text { regulators, and local people. }\end{array}$ & Usually high & $\begin{array}{l}\text { [242] Royal (2008) } \\
\text { [14] Barnett et al. (2012) }\end{array}$ \\
\hline Community Forums & $\begin{array}{l}\text { Similar to public exhibitions, but } \\
\text { focused on informing key stakeholders } \\
\text { within community. }\end{array}$ & $\begin{array}{l}\text { Limited bidirectional; focus on } \\
\text { proponent assessing concerns } \\
\text { of key actors. }\end{array}$ & Moderate & [242] Royal (2008) \\
\hline Opinion Research & $\begin{array}{l}\text { Mail, online or phone-based survey to } \\
\text { ascertain public opinion about a given } \\
\text { technology or proposed development } \\
\text { project. }\end{array}$ & $\begin{array}{l}\text { Unidirectional; information provided } \\
\text { to pollster by public. }\end{array}$ & Moderate* & $\begin{array}{c}\text { [242] Royal (2008) } \\
\text { [255] Student Energy (2015) }\end{array}$ \\
\hline Media Outreach & $\begin{array}{l}\text { Advertisements, interview appearances, } \\
\text { etc. in the mainstream media. }\end{array}$ & $\begin{array}{l}\text { Unidirectional; } \\
\text { media as mediator between } \\
\text { proponent and public. }\end{array}$ & Little to none & $\begin{array}{c}\text { [242] Royal (2008) } \\
\text { [254] Stokes (2013) } \\
\text { [94] Fast \& Mabee (2015) }\end{array}$ \\
\hline
\end{tabular}

* In the case of opinion research, although the public is invited to share its views, the proponent frequently maintains control of the questions posed to the public in the survey process. Thus, the questions asked can be limited, and the extent of opposition may be masked, or nuances of opinion lost. As a result, opinion research is assigned a moderate rating for the extent of public input, because proponents have the ability to filter their questions so as to limit the ability to voice opposition to a project.

Traditional forms of stakeholder and public engagement have received mixed reviews and have come under scrutiny from many stakeholder groups as the developers and regulators exert too much control over the process and outcomes. Other more innovative methods of engagement have included strategic environmental assessments and deliberative consultation. These methods have been put into practice in Nova Scotia addressing, for example, tidal energy development in the Bay of Fundy and wind farm policy development. The following table outlines these innovative stakeholder engagement techniques and provides insight into more innovative methods for engaging stakeholders in energy development discussions. 
TABLE 9 STAKEHOLDER CONSULTATION METHODS (INNOVATIVE)

\begin{tabular}{|c|c|c|c|c|}
\hline Method & Description & Directionality & Public Input & Source \\
\hline $\begin{array}{l}\text { Strategic Environmental } \\
\text { Assessment } \\
(\text { SEA) }\end{array}$ & $\begin{array}{l}\text { High-level planning exercise, carried } \\
\text { out by a government body designed } \\
\text { to assess available resources, } \\
\text { environmental impacts of harnessing the } \\
\text { resource, \& public concerns regarding } \\
\text { utilizing that resource. }\end{array}$ & $\begin{array}{l}\text { Fully bidirectional; government, experts, } \\
\text { scientists, public \& energy companies all } \\
\text { invited to share their perspectives } \\
\text { and concerns. }\end{array}$ & Usually high* & $\begin{array}{c}\text { [259] Tarr (2010) } \\
\text { [212] Oldrieve (2013) }\end{array}$ \\
\hline The Energy Walk & $\begin{array}{l}\text { A novel, audio-guided hike through the } \\
\text { town of Hanstholm, Denmark, designed } \\
\text { to educate participants on novel } \\
\text { renewable energy technologies \& their } \\
\text { place in the landscape. }\end{array}$ & $\begin{array}{c}\text { Mostly unidirectional; members of the } \\
\text { public listen to the provided audio guide } \\
\text { while walking; during research phase, } \\
\text { public was given chance to provide } \\
\text { feedback. }\end{array}$ & Low & $\begin{array}{l}\text { [282] Watts \& Winthereik } \\
\text { (2014) }\end{array}$ \\
\hline $\begin{array}{l}\text { Deliberative Consul- } \\
\text { tation }\end{array}$ & $\begin{array}{l}\text { Process in which all stakeholders } \\
\text { are brought together to discuss } \\
\text { potential options for development or } \\
\text { policy, guided by a neutral third party; } \\
\text { goal is consensus-based planning \& } \\
\text { decision-making. }\end{array}$ & $\begin{array}{l}\text { Fully bidirectional; all stakeholders have } \\
\text { a voice in deliberations, \& consensus- } \\
\text { as-goal means groups must discuss } \\
\text { things openly; concessions \& agreements } \\
\text { common. }\end{array}$ & High & [1] Adams et al. (2011) \\
\hline IT-based Approaches & $\begin{array}{l}\text { Take advantage of new technologies } \\
\text { to enable local people to provide } \\
\text { feedback \& help planning processes; } \\
\text { e.g., through the use of GIS markers } \\
\text { to help plan wind farms. }\end{array}$ & $\begin{array}{l}\text { Bidirectional; developer can provide } \\
\text { plans \& criteria, public can provide } \\
\text { feedback, alternatives \& suggestions. }\end{array}$ & High & [141] Higgs et al. (2008) \\
\hline Ethnography & $\begin{array}{l}\text { Carry out intensive studies of local } \\
\text { perceptions of place, technology } \\
\text { \& environment to design locally } \\
\text { appropriate solutions to energy issues. }\end{array}$ & $\begin{array}{l}\text { Mostly unidirectional; embedded } \\
\text { ethnographer gathers information } \\
\text { from \& learns about the community } \\
\text { to provide that information to planners } \\
\text { \& developers. }\end{array}$ & High & $\begin{array}{l}\text { [280] Watts (2009) } \\
\text { [281] Watts (2014) }\end{array}$ \\
\hline
\end{tabular}

* Note that this is based on best practice; a poorly executed strategic environmental assessment may have very little capacity for incorporating public opinion into the planning process the SEA is designed to inform.

Working toward social acceptance of an energy development project requires due diligence to stakeholder and public consultation. Developers and regulators must identify the goals of consultation early in the project and build processes to support these goals. If the goals are to build social licence, then ultimately the engagement process must focus on strategies to build trust, legitimacy and credibility. Processes that provide communication between and among project proponents and other stakeholders are essential. As well, developers and regulators must understand and be willing to provide some control to stakeholders. Processes that lack meaningful opportunities for dialogue and provide little if any stakeholder control over the outcomes of a project will likely be delayed in the current context of energy development in Canada.

\subsubsection{Where Does the Responsibility for Improvement Lie - Regulator or Proponent?}

Accommodating social licence should be the responsibility of both the regulator and the energy project component. Considering where responsibility lies requires an understanding of key partners in the regulatory process and their key concerns.

\subsubsection{First Nations}

To support the development of social licence in energy projects that involve First Nation communities (and most projects do), consultation should start at the earliest part of the 
process (as there is a duty to consult, as outlined in section 3.3 above). In fact, First Nation consultation is not part of the regulatory process; rather, the regulatory process triggers it. The Crown cannot delegate its responsibility to industry regarding First Nation consultation. Industry can and should be involved in discussions with First Nation groups potentially affected by energy development projects, but this does not replace consultation by government.

\subsubsection{Industry}

Companies should play a role in holding each other accountable. This should not replace regulatory processes and government, but serve to strengthen the system. Often, industry has information not accessible to government that can serve to strengthen the regulatory process and social licence. The addition of a whistle-blowing mechanism or ethics hotline should be developed for people within industry who have seen or heard something that needs to be reported. Often, in these cases there is no avenue for people to report on their own companies for fear of losing their jobs if they speak up.

A robust compliance system that could support social licence, including within the company, a framework for tracking post-approval attendance to possible concerns, is an option to explore. A robust compliance system could track annual reports (e.g., on state of the environment) covering:

- Disposition approvals issued;

- Compliance - warnings, court cases, orders, penalties;

- Reclamation certificates;

- Abandoned and suspended operations;

- Economic revenue generator;

- Royalties - forestry, aggregate, hydroelectric;

- Impacts to trapping, fishing, hunting.

\subsubsection{The Public}

Nova Scotia's Strategic Environmental Assessment (SEA) for Tidal Energy Development - Bay of Fundy provides an example on how to engage local stakeholders in informing the regulatory process. In 2008, the Offshore Energy Research Association (OERA) commissioned the Strategic Environmental Assessment (SEA) for Tidal Energy Development - Bay of Fundy. The purpose of this report was to prepare a state-ofknowledge review of known environmental and socio-economic issues with respect to tidal energy development in the Bay of Fundy. In addition, following the development of the initial phase of the report, six public meetings were held in Bay of Fundy communities where findings were shared with stakeholders and their perspectives on tidal energy development in the Bay of Fundy were gathered in a community consultation report.

Supporting participation of stakeholders was a research and participation fund set aside for them. Community consultation meetings were structured as consultation and information-sharing sessions where stakeholders were encouraged to express their concerns 
related to tidal energy development. The outcomes of the SEA process resulted in 29 recommendations to guide the development of tidal energy in Nova Scotia. Examples of recommendations include the adaptation of sustainability principles, a Mi'kmaq ecological study, an incremental development approach, public education and awareness, relevant legislation to guide tidal energy development, and community participation and benefits. These recommendations were revisited in 2013 with a Strategic Environmental Assessment (SEA) for Tidal Energy Development - Bay of Fundy Update. Since that period, Nova Scotia has developed a marine energy strategy to guide development and the regulatory process.

With the SEA, stakeholders were presented with the most recent scientific evidence on the potential impacts of tidal energy development, provided funds, if requested, to enhance their participation, and then asked to comment on how this type of energy development should progress in the province with respect to regulation. Many of the 29 recommendations were based largely on input from stakeholder consultation. Some of these recommendations have been noted previously, but it is important to highlight some of these again as they represent factors that work toward building public acceptance. These include:

- Development of tidal energy should advance incrementally using the precautionary principle;

- Ensure community participation and benefits;

- Develop sustainability principles to guide development of tidal energy;

- Develop legislation and regulatory frameworks to support and guide tidal energy development.

\section{CONCLUSIONS}

\subsection{Historical Context}

To situate our discussion of social licence in a broader context, it is helpful to appreciate the historical perspective. During much of the 20th century, the regulation of energy followed the overarching trajectories of societal views on the proper role of government. The Great Depression of the 1930s represented to many the ultimate market failure, as markets, left to their own devices, were unable to provide sufficient employment. During the ensuing decades, the political pendulum swung to the left with ever-increasing roles for governments at various levels, including in energy industries.

However, the stagflation of the 1970s constituted a major government failure - macroeconomic policies could not resolve the twin scourges of inflation and unemployment, which had been exacerbated by oil price shocks. This was not entirely, or perhaps even primarily, a failure of macroeconomic monetary and fiscal policy. Regulatory burden had risen dramatically over the preceding decades, to the point where many industries were highly regulated. Growing evidence that regulation and government intervention had over-reached resulted in calls for reducing government's role. The political pendulum began to swing to the right with the elections of Margaret Thatcher, then Ronald 
Reagan, and still later, Brian Mulroney. Various industries experienced deregulation, some with stunning success - for example, the telecommunications industry. There was increased reliance on market forces and privatization. The economic growth experienced in the following decades was very much related to the deregulation that had occurred. The success in telecommunications was followed by impressive growth in other industries. In areas where regulation continued to be required, forward-thinking regulators shifted from comprehensive approaches to light-handed variants: "competition where possible, regulation where necessary," as it were. In energy, the traditional cost-of-service regulatory model shifted to incentive regulation, the most common variant of the latter being price-cap regulation.

The verdict of the 20th century ideological drama that pitted societies based on market models against those based on central planning came out unequivocally in favour of the former. Liberalization, marketization and privatization were not limited to Western democracies. China's strong growth in this century can be traced to modest liberalization policies begun in the late 1970s. The dissolution of the Soviet Union resulted in a shift to market economics and multi-party democracy in a number of the previous Soviet satellites and republics. Certain South American countries also engaged the deregulation agenda, with varying degrees of success. This period of deregulation in less-developed economies led not only to growth, but by many measures, to a reduction in global inequality as hundreds of millions were lifted out of the most extreme forms of poverty.

The fundamental message of this competition of ideas was that market deficiencies merited correction and not replacement with bureaucratic central planning.

By the 21st century, it appeared that in some areas, deregulation had gone too far. The failure of Enron in 2001 was small in comparison to the financial precipice of 2008, although Canada's conservative approach to banking regulation allowed it to weather this period relatively uneventfully.

Today, energy industries face what some have argued is the ultimate market failure - the externalities caused by the combustion of hydrocarbons, which are the source of about 80 per cent of energy world-wide. (In Canada, because of our vast endowments of hydroelectric power, hydrocarbons comprise a somewhat smaller share of the energy we consume.) De-carbonization has become an increasingly prominent objective of policymakers, often with greater rather than lesser reliance on market forces. Cap-and-trade is an especially salient example whereby property rights in the form of emission permits are created and traded to reduce the costs of de-carbonization.

There is a risk that the financial meltdown and climate-related imperatives may lead to a new era of increasing regulation. This path would ignore the lessons of the previous century - regulation may be required, but it should be relied upon where it is necessary, and implemented in sensible ways.

It is against this historical backdrop that one needs to evaluate social licence. 


\subsection{The Energy Trilemma Revisited}

Early in this document, we set out the three key apexes of the energy trilemma, viz., that in arriving at policies and decisions, decision-makers evaluate the economic, environmental and security consequences of a particular path, balancing considerations in each area against the others.

Economic considerations, at a minimum, involve a cost-benefit analysis to determine whether the proposed project makes sense from a financial perspective. There are also often broader economic issues to be considered, for example, whether the project is likely to promote economic growth and net job creation.

Environmental considerations vary based on the project and they can be local, regional or national. For example, wind farms may have an adverse impact on local inhabitants, but relative to hydrocarbon electricity generation provide a clean and carbon-free supply of energy which benefits all. We will return in greater detail to environmental issues below.

Security considerations, in the first instance, usually refer to a reliable supply of energy, availability of infrastructure and protection thereof. However, energy security can also play an important role in promoting national security. Just as many argue that Canada has a responsibility to do its share in mitigating climate change and alleviating global poverty, it could also be argued that it has a duty to protect the ideals of liberal democracy upon which it is founded, and to support allies and similarly minded nascent democratic movements.

There are also interactions among the three elements of the trilemma. Access to energy promotes economic growth and prosperity. Economic strength has been, and continues to be, essential to maintaining national security. Today, climate change itself is seen increasingly as a security issue, especially if changing local climates lead to droughts, food and water shortages, or rising sea levels lead to flooding of heavily populated regions with consequent migration of peoples.

Once a certain level of economic prosperity is achieved, increased attention is devoted to environmental matters - the so-called Environmental Kuznets Curve. A country that finds it difficult to meet its population's basic needs is not likely to devote major resources to switching from relatively cheap coal to more expensive but cleaner fuels, such as natural gas or renewables. Even advanced economies struggle to balance environmental goals against the economic needs and desires of their populations.

\subsection{Subsidiarity and Separation}

The principle of subsidiarity states that decisions should be made, and tasks should be performed, at the lowest level in a hierarchy at which they can be competently decided and effected. One of the implications is that governments should undertake responsibilities only if individuals, groups of individuals or organizations (such as firms) cannot fulfil them competently on their own. The principle generally favours decentralization. It is helpful in illuminating lines between private and public spheres, it provides a rationale for markets (as opposed to central planning), it is helpful in establishing regulatory boundaries, and it 
is useful for allocating responsibilities across local, provincial and federal governments. A related idea, that of clear definition and separation of responsibilities as between regulatory agencies and political entities, is also helpful.

In discussions of energy issues, these two ideas - subsidiarity and separation - have many implications. Their relevance to the discussion of social licence can be illustrated by the following examples, siting of wind farms and siting of natural gas generation.

Siting of wind farms: In 2009, Ontario embarked on an ambitious renewable energy program. Feed-in tariffs were established for wind and solar generation, as well as for other forms of renewable energy. The generosity of the tariffs elicited a very strong supply response - within a year, proposals totalled 15,000 MW, more than half of Ontario's peak load. The province proceeded with siting approvals without sufficient consultation at local levels. This heavy-handed, top-down approach led to significant pushback. A preferable approach would have been to allow local governments and communities to make decisions about siting, perhaps with some form of compensation to affected parties. Given the volume of applications and the range of geographical options, (admittedly constrained by the spatial configuration of Ontario's transmission and distribution networks), the objectives of the program would likely have been achieved with lower political friction and greater societal benefit, had siting choices been made at lower levels in the hierarchy.

Siting of natural gas generation: In the face of aging facilities, retirement of coal-fired generation and the need for peaking plants, Ontario put forth a plan to develop gas-fired generators at various locations around the province. However, shortly before an election, and after considerable pressure from certain affected communities, the government decided to cancel two plants which were to be located in Toronto suburbs. The reversal would cost Ontario ratepayers hundreds of millions of dollars. How could this misadventure have been avoided? In this case, the key is separation of political decisions from regulatory ones; that is, an arm's-length relationship between politicians and the regulator, with the latter having the power and authority to effect its decisions. Consider two stylized scenarios.

In the first, there exist no reasonable alternatives to siting gas generators in Toronto suburbs. In this case, the government will be less tempted to make a politically motivated last-minute cancellation decision because it cannot be blamed for it. The regulator will take the heat, as it were.

In the second scenario, there are reasonable alternative siting locations. In this case, the regulator hears representations from the various communities to determine which would be more amenable to accepting the facility, which might bring associated benefits, such as job creation.

Under each scenario, it may be necessary for the regulator to seek allowances or support from the government if some sort of direct or indirect compensation is necessary to realize the plans.

In both of the above examples - siting of wind farms and of gas generators - trust and confidence in the decision-making process were undermined. However, the creation of a new and vague requirement, such as social licence, would likely further politicize the 
decision process in a detrimental fashion. The more efficacious solution would seem to be to endow the regulator with the authority to make and effect decisions without the unpredictability and partisanship of political intervention.

The implication of subsidiarity is that policy should be set by politicians, for implementation by regulators in consultation with market participants and affected parties. Political entities are qualified to set broad policy directions for energy industries. However, regulatory agencies with staff that have worked in the industry over extended periods of time are much more qualified to make implementation decisions.

The thrust of these arguments is that public trust and confidence can be enhanced by rationalizing existing regulatory vehicles to reduce the common perception (not unrelated to reality) that decisions are sometimes politically motivated (i.e., separation) and ensuring that decisions are made at the right levels (i.e., subsidiarity).

\subsection{Equity and Efficiency}

It is a fundamental tenet of economics that pricing mechanisms that reflect underlying costs lead to rational, socially optimal allocations of resources. Relatively efficient markets, with limited price distortions are socially desirable. Well-functioning markets also require sustained investment in capital assets, and in research and development to drive innovation. Predictable government policy, an efficient and efficacious regulatory process, and simple protections that allow firms to conduct their business without undue obstruction, are all important contributory elements to economic efficiency and prosperity.

At the same time, new energy projects and more broadly, changes in regulatory and governmental policies, with few exceptions, have differential impacts across various segments of the population. They are rarely Pareto-improving. In most circumstances, there are individuals and groups who are adversely affected. How does one deal with these distributional impacts?

Conceptually, it is important to separate economic productivity and efficiency from distributional consequences. While suitable compensation may be appropriate for affected parties, one wants to achieve this with minimum price distortion or impact on productivity. Mitigation of impacts is often a complex and delicate matter, and may involve political compromise.

In this context, what are the implications for the institutionalization of social licence? First, there are likely to be increased incentives for rent-seeking behaviour. The threat of veto, or even obstruction, endows the affected group with leverage that can result in extraction of rents that are disproportionate to impacts. Second, a requirement of social licence increases regulatory and political uncertainty associated with a given project, discouraging investment, or requiring returns higher than are merited by the inherent riskiness of the proposed undertaking. In this case, prices in capital markets are distorted. 


\section{RECOMMENDATIONS FOR POLICY-MAKERS AND REGULATORS}

Canada is one of the most decentralized federations in the world. It is also hugely varied geographically, with different regions having very different energy sources, as well as somewhat different uses for energy. For major energy infrastructure projects that involve a single province, let alone more than one province, achieving regional, provincial and aboriginal agreements and commitments to action is critical — yet is often very difficult. ${ }^{123}$

As we have seen from this paper, the legitimacy of the process, and public trust in it, are key elements in moving projects forward. Public perception of this legitimacy seems eroded based on criticism that the regulatory process has not adequately addressed certain environmental concerns (including climate change) or Aboriginal rights. (No process will solve all concerns to everyone's satisfaction - the goal of the process is to balance the various economic, environmental and social issues at hand. However, to be legitimate, this paper suggests that the process needs to be better at including these additional concerns as part of the larger process).

In addition, although the law on jurisdiction for such projects is straightforward, political willingness to enforce it is needed. In a democracy such as ours, leadership that helps achieve consensus is far more effective, particularly in the long run, than force. To this end, the provinces, territories and Aboriginal communities must be involved in the discussion of how to improve the regulatory process and the level and type of engagement in order to ensure trust in the process by their respective constituencies. It is important that all participants - the provinces and territories, their political leadership, and Aboriginal communities not otherwise represented by the provinces and territories - trust the national and provincial regulatory processes. After all, although the process is to determine if projects are in the national or provincial interest, they have various effects on communities in the various provincial, territorial and aboriginal jurisdictions, for which those local governments are responsible.

\subsection{Governmental Co-ordination}

Greater co-ordination of regulatory processes between the federal and provincial governments is required and should be directed towards enhancing beneficial outcomes for all affected stakeholders.

The recent agreement by the provinces and territories on a Canadian Energy Strategy (CES) is a start. Although much of the language is vague and aspirational, as opposed to providing for concrete action, there is more consensus than before, including, among other

123 Technically, the law is relatively straightforward: As long as an activity remains wholly within a province (subject to a few key exceptions), that province is responsible for applicable regulation, taxation and the like. Once any of the project's activities cross provincial borders, however, such as transportation via pipeline or rail to reach other markets, it comes under federal jurisdiction. Under the constitution, the federal government has jurisdiction over "Works and Undertakings connecting the Province with any other or others of the Provinces, or extending beyond the Limits of the Province" (BNA Act, s.92.10(a)) and "such Works as, although wholly situate within the Province, are before or after their Execution declared by the Parliament of Canada to be for the general Advantage of Canada or for the Advantage of Two or more of the Provinces." (BNA Act, s.92.10(c)). The federal government is also responsible for trade and commerce, and the courts have confirmed that this includes both international trade and interprovincial trade. Technically, no province can prevent another from carrying commodities to export markets by preventing transit. 
things, confirming the need for more oil pipelines and other energy infrastructure, and committing to cutting regulatory red tape so projects can be approved. Importantly, the agreement provides for ongoing work on details. Notably, however, the federal government is completely absent, even though national infrastructure activities fall within federal jurisdiction.

The provincial and territorial governments must, under the auspices of the CES:

- Set a clear timeline for concrete decisions on details to improve the regulatory process, with involvement by Aboriginal communities;

- Be clear that they understand the role of the federal government and the need for the federal government to be at the table.

The federal government must:

- Acknowledge that it has the legal and political responsibility to move forward projects that are in the national interest;

- Acknowledge that it has a key role in determining what is in the national interest, but that input from the provinces, territories and Aboriginal communities is important;

- Announce clear policies balancing economic, environmental and social interests — the regulatory process should not make policy, but implement it;

- Announce an effort to review and improve, where possible, the regulatory process, working with the provinces and territories, using as a starting place the work being done under the auspices of the Canadian Energy Strategy. For this purpose, it should establish a non- or multi-partisan, widely respected panel to make recommendations for improvements to the regulatory process for major infrastructure projects, working with those involved with the Canadian Energy Strategy, to improve efficiency, transparency, inclusiveness and effectiveness in implementing what should be clear and well-communicated policies;

- Establish a clear timeline for conclusion of such review and to implement recommendations;

- Be clear that, once an improved regulatory process is implemented, it will enforce the resulting decisions, and that as the provinces, territories and Aboriginal communities were involved in such improvements, the federal government will insist that provincial, territorial and Aboriginal authorities enforce such decisions locally as well.

\subsection{Stakeholder Engagement}

Regulators are placed in a difficult position, because they need to determine whether a body has standing and how much weight should be given to that entity's position. Can anyone become a stakeholder who has an opinion on an energy project? Or should stakeholders be only those directly affected by the project? How do you determine who is affected and to what extent? Developing a transparent process for identifying stakeholders and providing a venue for stakeholders' voices to be heard can build legitimacy in the regulatory process. An energy project that lacks a meaningful stakeholder engagement process can lead to further politicization of the process and delays in a decision. 
A consistent, transparent and rigorous system for identifying and reaching out to stakeholders is essential to regulatory efficiency and efficacy. Principles and practices of stakeholder and community engagement should be further articulated by key regulators and could appear as an addendum to the Canadian Energy Strategy. The document would highlight key principles and processes that serve to promote social acceptance of energy development.

\subsection{Social Licence as a Concept}

When it comes to energy development, the term "social licence" needs to be further analyzed, and, if used, used with care. The concept originated in the mining sector as the "social licence to operate," and applied uniquely to the activities of mining companies vis-à-vis individual projects. As the concept has migrated to the energy sector, it appears to have broadened in scope beyond the realm of corporate social responsibility, applying not only to energy companies' activities, but to the regulatory process and even to energy policy frameworks in toto. In the process, its meaning has become unclear, amorphous and confusing, and taken to its extreme, could suggest that energy projects should not proceed unless every single Canadian, ENGO, industry, community, etc., supports them, a standard that is unlikely - if impossible — to meet in practice. Other terms such as "acceptance," "support" or "public confidence" may be more appropriate in the energy sphere. Regulators, policy-makers and politicians should refrain from the use of these terms without a clear understanding of their implications.

\subsection{First Nations}

First Nations are rights holders and thus, different from stakeholders, such as the general public. First Nations rights are recognized in the Canadian constitution, and a whole body of law exists that sets out how governments must consult and accommodate First Nations people. Social licence, as it pertains to Aboriginal-Canadians, should be viewed as secondary or supplemental to the legal duty to be consulted and accommodated, and the right of consent where it applies.

The federal and provincial governments should take ownership of this duty to consult and ensure that it is done in a comprehensive manner that has been set out by both domestic and international law. Development of consistent processes across levels of government around consultation will enable greater uniformity and consistency in how consultation is undertaken, making the process more fair and equitable. In addition, best practices from Aboriginal consultation and engagement could be used to improve public consultation, and vice versa, potentially leading to higher levels of public acceptance of energy projects.

\subsection{Changes to the NEB Act}

Though there is only a single court challenge to the 2012 changes to the NEB Act through Bill C-38, the challenge asserts the changes reduce federal environmental protection, and 
reduce federal assessment of resource development. ${ }^{124}$ Additional changes included the establishment of time limits on regulatory processes and who can participate in regulatory hearings. These issues have been frequently raised as reasons for opposition to the regulatory process.

The National Energy Board, as with all regulators, must balance the efficiency, inclusiveness and efficacy of the review process to ensure all appropriate evidence is heard in a timely manner. Whether or not the changes to the NEB Act in 2012 have undermined the ability of the NEB to maintain this balance, the changes appear to have undermined the National Energy Board's credibility, and subsequently undermined the legitimacy of the regulatory process. ${ }^{125}$ An independent review of the changes to the NEB Act regarding time to consult and the list of those who can be consulted should be undertaken to ensure the NEB is unconstrained in its ability to regulate appropriately and has the public's confidence in its mandate and decisions. As the federal government moves forward with its agenda to modernize the NEB, it should convene an independent committee to review the 2012 changes and make recommendations on changes to the NEB Act or the Canadian Environmental Assessment Act to ensure the goals of increased public confidence and trust are met.

\subsection{Make Broader Use of Information Gained during Assessment Processes}

Energy regulators such as the NEB often conduct lengthy and thorough reviews of the opinions of Canadians when making decisions in the public interest. However, for practical and statutory reasons, the scope of topics that can be considered when making such decisions is typically limited. For example, hearings on the siting of wind energy projects before Ontario's Environmental Review Tribunal have been focused on the narrow questions of human health and irreversible impacts on wildlife, though some parties have attempted to raise other considerations. For Canadians expressing concerns that are deemed outside the scope of a hearing's mandate, this can be frustrating. It also represents a lost governance ${ }^{126}$ opportunity to identify and consider potential root causes of opposition to energy projects.

Energy regulators should consider mechanisms to report recurring concerns that are outside of the scope of their mandate. Bodies such as the NEB or the Environmental Review

124 [161] J. Kennedy, M. Ignasiak, and S. Duncanson, "Alberta First Nations Challenge Constitutionality of Federal Regulatory Reforms," Jan. 9, 2013, Osler Blog.

${ }^{125}$ Garud et al distinguish between credibility, or "the trustworthiness ascribed to a source or finding," and legitimacy, or "the acceptability of constitutive practices," ([105] Garud, Gehman, and Karunakaran, "Boundaries, Breaches, and Bridges: The Case of Climategate." Research Policy, 43(1) 2014). As they note, a finding can be credible, but based on practices that are considered to be illegitimate, such as conducting research without institutional review board approvals. Conversely, it is possible for legitimate practices to generate findings that audiences consider to lack credibility, such as the recommendation by the United States Preventive Services Task Force (USPSTF) that most women in their 40s no longer need mammograms, whereas starting at age 50, they are advised to have one every two years ([271] United States Preventative Services Task Force. 2009. "Breast Cancer Screening"). Of course, the two constructs can interact, as when the credibility of a finding is impacted by the legitimacy of the practices followed.

${ }^{126}$ Governance has multiple meanings. Here it is taken to mean a system of governing that combines both state and non-state actors ([34] H. Bulkeley, "Reconfiguring Environmental Governance: Towards a Politics of Scales and Networks," Political Geography, 2005). Doern and Gattinger’s definition of energy regulatory governance is also helpful: “... the processes and structures through which regulations are developed and implemented, and the ideas and ideals underpinning decisionmaking” ([77] G. B. Doern \& M. Gattinger, Power Switch, 2003:13) 
Tribunal in Ontario are on the front line in engaging with Canadians' energy concerns. The information gathered by these bodies can and should be utilized more broadly to help ensure our regulatory public participation processes speak back to policy-makers. This is not to say that regulators should reach beyond their statutory mandates in making decisions, only that recurring concerns should be highlighted and made available for policy-makers, industry and civil society to consider. Such information, delivered alongside an easily digestible summary of the rights and duties of regulators, may increase transparency and build trust in the activities of regulators.

\subsection{Compliance after Project Approval}

Information on compliance subsequent to project approval (e.g., warnings, infractions, penalties, court cases, reclamation certificates and abandoned operations) should be available in transparent forms that are accessible by the different interested stakeholders. Methods for sharing and making this information public should be strengthened and improved. In some cases, regulators may want to consider partnering with other organizations in the translation and dissemination of such information.

Canada's energy sector is regulated with both national and provincial regulators, with responsibility of such regulation varying between provinces. There is a need for publicly available, timely and relevant data relating to the compliance and post-approval status of projects. Stakeholders would be best served if regulators could identify and agree upon the required content of such data and use a common format and presentation medium so that data are meaningful and comprehensible and not steeped in the industry and its jargon and processes. Data should be placed on a government portal to increase accessibility to stakeholders.

\subsection{Cross-Examination in Regulatory Hearings}

Regulatory proceedings typically involve lengthy submissions by various stakeholders and intervenors, and often by various governmental entities. Evidence given and tested under oath adds to the credibility of the process, and may therefore contribute to public acceptance. Although adversarial procedures are costly in terms of time and resources, they serve an important purpose within which the interrogatory process and cross-examination are important tools. The extensiveness of permitted cross-examination, and indeed the entire regulatory proceeding, needs to be proportionate to the magnitude of the impacts of the ultimate decision. 


\section{APPENDIX: BACKGROUND AND METHODOLOGY}

\section{Background to the Study}

This research is part of the Canadian Network for Energy Policy Research and Analysis, an initiative designed to address pan-Canadian energy policy issues. The Canadian Network for Energy Policy Research and Analysis (the Network) is a virtual and physical research forum based at the School of Public Policy at the University of Calgary. Each year, the Network brings together academics from across Canada, forming an expert panel (the Working Group) that produces a white paper on a current energy policy issue.

The Network is managed by a program director at the School of Public Policy, and is supported by a post-doctoral scholar and an advisory committee. Following an advisory committee meeting in September 2015, where pendant energy policy topics were discussed, the program director selected the topic of "social licence in Canadian policy." Soon after, a working group of scholars was selected from across Canada to further refine the topic, define the problem(s) to be answered, and determine the terms of the project.

\section{Approach of the Working Group}

The inaugural meeting of the Working Group occurred in Toronto in November 2014. During this meeting, the topic of the paper was explored and further refined to explore the role of public acceptance and the regulatory process with respect to energy project development. The research question agreed upon at this point was "When it comes to public acceptance of energy projects, is Canada's regulatory system broken/working?" In approaching the research question, the Working Group relied primarily upon extant research, as it was not feasible to conduct primary research within the resource and time constraints of the project. A loose framework for the paper was developed and further refined through a series of conference calls soon after the inaugural meeting. Members of the Working Group were assigned to various sections of the paper based on expertise and interest. In some cases, multiple authors contributed to sections of the paper.

Members of the Working Group held varying opinions on the value and utility of the concepts of social licence, social acceptance and public acceptance. While all members did not agree on the value and utility of some of the key concepts underlying the paper, most notably the term "social licence," there was consensus on the structure and scope of the paper.

Other than three in-person meetings (Toronto, Calgary and Ottawa), the bulk of the business in developing the paper occurred via conference call. In these calls, key decisions were made regarding the structure and scope of the paper. As early drafts of the paper emerged, discussions centred on key edits and other suggestions necessary for strengthening the paper. As the first draft emerged, significant attention was paid to 
recommendations highlighting suggestions for improving the regulatory process with respect to social acceptance and energy development. Conference calls were made on the following dates:

- Feb. 17, 2015

- March 24, 2015

- April 28, 2015

- May 20, 2015

- May 26, 2015

- June 18,2015

- July 16, 2015

- Aug. 19, 2015

- Aug. 26, 2015

- Dec. 15,2015

- Dec. 21, 2015

- Feb. 22, 2016

\section{Stakeholder Workshop (Calgary) Jan. 15, 2015}

A focus of the Network is engagement and open discussion on policy issues, and a key component in the development of the white paper was a stakeholder workshop that has an open dialogue around the question the Working Group addressed. Stakeholders were invited to attend a full-day workshop to discuss the concepts of social licence and public acceptance, and to comment on the Working Group's proposed research agenda. Attendance at this workshop was over 50 people, including the Working Group.

\section{Development of the Paper}

Working Group members worked independently on their assigned sections of the paper. Through an iterative process of completing and reviewing drafts of the paper supported by extensive literature reviews, conducted independently by each member of the Working Group in support of their section, a draft of the paper emerged. Working Group members reviewed the emerging complete draft of the paper, providing feedback as necessary to the corresponding authors. A final draft for initial stakeholder review was completed in September 2015. Accompanying this draft were a series of key recommendations to address challenges related to social acceptance and the regulatory process with respect to energy development. These recommendations were crafted after significant Working Group deliberations with respect to the paper's findings. 


\section{Stakeholder Conference (Ottawa) Sept. 15, 2015}

A draft of the paper, entitled Energy Projects, Public Acceptance and Regulatory Systems in Canada: A White Paper was released for external review to key stakeholders in government, industry, academia and NGOs. A conference was held in Ottawa on Sept. 15, 2015 to solicit feedback on the draft of the paper. An overview of the paper was presented and each of the paper's recommendations was highlighted. Formal comments were given by Mr. Blaine Favel, Dr. Marie-José Fortin, Mr. Rowland Harrison (Q.C.), and Dr. Ian Lee. Significant discussion on the merits of the paper and its recommendations highlighted key strengths and weaknesses of the draft paper. Stakeholder feedback on the paper, both oral and written, was collected and summarized. Over 70 people attended, and approximately 15 additional people listened in via conference call.

\section{Peer Review}

Using these inputs together with his own reading, the research director at the School of Public Policy provided the Working Group with a formal decision letter in November 2015, which included his guidance on final revisions to the paper. Between January and March 2016, the Working Group revised the paper to address the feedback provided by stakeholders, further refining key issues in the paper as well as providing more clarity to the recommendations as necessary. 


\section{REFERENCES}

[1] Adams, M., D. Wheeler, and G. Woolston, 2011. "A Participatory Approach to Sustainable Energy Strategy Development in a Carbon-Intensive Jurisdiction: The Case of Nova Scotia.” Energy Policy 39: 2550-2559. doi: 10.1016/j.enpol.2011.02.022.

[2] Aitken, M. 2010. "Wind Power and Community Benefits: Challenges and Opportunities." Energy Policy 38(10): 6066-6075.

[3] Alberta Ministry of Aboriginal Relations. 2015. Aboriginal Consultation Office Q\&A. Retrieved from http://www.aboriginal.alberta.ca/573.cfm

[4] Aldrich, Howard E., and C. Marlene Fiol. 1994. "Fools Rush in? The Institutional Context of Industry Creation." Academy of Management Review 19: 645-670.

[5] Allan, R. April 14, 2014. "Notice of Motion.” Retrieved from https://docs.neb-one. gc.ca/1l-eng/1lisapi.dll/fetch/2000/130635/2450279/Notice_of_Motion_1_Robyn_Allan_ April_14\%2C_2014___A3V8U7.pdf?nodeid=2450280\&vernum $=-2$

[6] Alvial-Palavicino, C., N. Gamido-Echeverria, G. Jiménez-Estévez, R. Palma-Behnke, and L. Reyes. 2011. "A Methodology for Community Engagement in the Introduction of Renewable-Based Smart Microgrid. Energy for Sustainable Development 15, 314-323.

[7] American Wind Energy Association AWEA. 2015. "Wind Energy facts at a Glance." Retrieved from http://www.awea.org/Resources/Content.aspx?ItemNumber=5059

[8] Auditor General of Ontario. 2011. 2011 Annual Report. Toronto: Queen's Printers Press of Ontario. Retrieved from http://www.auditor.on.ca/en/content/annualreports/arbyyear/ ar2011.html.

[9] Bagozzi, R. P., Y. Yi and L. W. Phillips. 1991. "Assessing Construct Validity in Organizational Research.” Administrative Science Quarterly 36: 421-458.

[10] Bailey, I. June 18, 2014. “"The War is On': Protesters Set Sights on Harper After Northern Gateway Decision.” Globe and Mail. Retrieved from http://www.theglobeandmail.com/ news/british-columbia/the-war-is-on-protesters-set-sights-on-harper-after-northerngateway-decision/article19214575/

[11] Bailey, I. Nov. 24, 2014. "Protesters Rally Against Trans Mountain Pipeline, but Drilling Continues." Globe and Mail. Retrieved from http:/www.theglobeandmail.com/news/ british-columbia/protestors-rally-against-trans-mountain-pipeline-but-drilling-continues/ article21743986/

[12] Bankes, N. June 24, 2015. "The Social Licence to Operate: Mind the Gap." ABlawg. Retrieved from http://ablawg.ca/wp-content/uploads/2015/06/Blog_NB_SLO_June2015. pdf p.2

[13] Bansal, Pratima, and Iain Clelland. 2004. "Talking Trash: Legitimacy, Impression Management, and Unsystematic Risk in the Context of the Natural Environment." Academy of Management Journal 47(1): 93-103. 
[14] Barnett, J., K. Burningham, N. Cass, and G. Walker. 2012. "Imagined Publics and Engagement Around Renewable Energy Technologies in the UK." Public Understanding of Science 21(1): 36-50.

[15] Barry, J., and G. Ellis. 2010. "Beyond Consensus? Agonism, Republicanism and a Low Carbon Future." In Renewable Energy and the Public: From NIMBY to Participation. Edited by P. Devine-Wright. London: Earthscan, 29-42.

[16] Batel, S., P. Devine-Wright, and T. Tangeland. 2013. "Social Acceptance of Low-Carbon Energy and Associated Infrastructures: A Critical Discussion.” Energy Policy 58: 1-5.

[17] Baxter, J., R. Morzaria and R. Hirsch. 2013. "A Case-Control Study of Support/ Opposition to Wind Turbines: Perceptions of Health Risk, Economic Benefits, and Community Conflict.” Energy Policy 61: 931-943.

[18] Bazilian, M., I. Onyeji, M. Liebreich, I. MacGill, J. Chase, J. Shah, and S. Zhengrong. 2013. "Reconsidering the Economics of Photovoltaic Power." Renewable Energy 53: 329338.

[19] Bell, D., T. Gray and C. Haggett, 2005. "The 'Social Gap' in Wind Farm Siting Decisions: Explanations and Policy Responses.” Environmental Politics 14(4): 460-477.

[20] Bell, D., T. Gray, C. Haggett, and J. Swaffield. 2013. "Re-visiting the 'Social Gap': Public Opinion and Relations of Power in the Local Politics of Wind Energy." Environmental Politics 22(1): 115-135.

[21] Beltrame, J. Oct. 3, 2013. "Quebec Fracking Ban Lawsuit Shows Perils Of Free Trade Deals: Critics." Huffington Post. Retrieved from http://www.huffingtonpost.ca/2013/10/03/ quebec-fracking-ban-lawsuit_n_4038173.html

[22] Bice, S. 2014. "What Gives You a Social Licence? An Exploration of the Social Licence to Operate in the Australian Mining Industry." Resources 3(1): 62-80.

[23] Bitektine, A. 2011. "Toward a Theory of Social Judgments of Organizations: The Case of Legitimacy, Reputation, and Status.” Academy of Management Review 36(1): 151-179.

[24] Black, L. 2013. The Social Licence to Operate: Your Management Framework for Complex Times. Saltaire, U.K.: Do Sustainability.

[25] Bobko, P. 2001. Correlation and Regression, vol. 2nd. Thousand Oaks, CA: SAGE Publishing.

[26] Boothe, P. 2013. “Making Good Regulations," Canadian Public Policy 39(3): 359-370.

[27] Boutilier, Robert G. Aug. 30, 2014. "Frequently Asked Questions About the Social Licence to Operate." Impact Assessment and Project Appraisal 32: 263-272.

[28] Boutilier, R. G., L. Black, and I. Thomson. 2012. "From Metaphor to Management Tool: How the Social Licence to Operate Can Stabilise the Socio-Political Environment for Business." 227-237. Presented at the International Mine Management. Melbourne: Australasian Institute of Mining and Metallurgy. 
[29] Boutilier, R. G., and I. Thomson. 2011. "Modelling and Measuring the Social Licence to Operate: Fruits of a Dialogue Between Theory and Practice." Retrieved from http://www. socialicense.com/publications/Modelling\%20and\%20Measuring\%20the\%20SLO.pdf.

[30] Bowness, E., and M. Hudson. 2014. "Sand in the Cogs? Power and Public Participation in the Alberta Tar Sands." Environmental Politics 23(1): 59-76.

[31] British Wind Energy Association. 2002. "Best Practices Guidelines: Consultation for Offshore Wind Energy Developments." Retrieved from http://www.bwea.com/pdf/bweabpg-\%20offshore.pdf

[32] Brokenhead Ojibway Nation et al. v. A.G. (Can.), 2009 FC 484.

Retrieved from https://docs.neb-one.gc.ca/ll-eng/llisapi.dll/fet

ch/2000/90464/90552/643663/661686/666213/722943/A2E3S9_-_Brokenhead_Ojibway. pdf?nodeid $=723176 \&$ vernum $=-2$

[33] Business for Social Responsibility. 2003. "The Social Licence to Operate.” San Francisco, CA: Business for Social Responsibility, 2003. Retrieved from http://www.sdsg.org/wpcontent/uploads/2013/04/file_BSR_Social_Licence_to_Operate.pdf

[34] Bulkeley, H. 2005. "Reconfiguring Environmental Governance: Towards a Politics of Scales and Networks." Political Geography 24(8): 875-902.

[35] Business Council of British Columbia. 2015. "Rethinking Social Licence to Operate - A Concept in Search of Definition and Boundaries," Environment and Energy Bulletin 7(2). Retrieved from http://www.bcbc.com/publications/2015/rethinking-social-licence-tooperate-a-concept-in-search-of-definition-and-boundaries

[36] Callon, M., Y. Barthe, and P. Lacoumes. 2009. Acting in an Uncertain World: An Essay on Technical Democracy. Translated by G. Burchell. Cambridge, MA: The MIT Press.

[37] Canada West Foundation. 2013. "Unpacking Social Licence: Towards a Framework for Addressing the Social Licence Challenge Facing the Natural Resource Sector." Retrieved from http://cwf.ca/pdf-docs/publications/Unpacking\%20Social\%20Licence_Fall2013RRT. pdf

[38] Canadian Environmental Assessment Agency. Oct. 31, 2013. "Report of the Federal Review Panel: New Prosperity Gold-Copper Mine Project.” Retrieved from http://www. ceaa-acee.gc.ca/050/documents/p63928/95631E.pdf.

[39] Canadian Environmental Assessment Agency. Feb. 25, 2014. "Decision Statement." Retrieved from http://www.ceaa-acee.gc.ca/050/document-eng.cfm?document=98458

[40] Canadian News Wire. July 22, 2015. "PVLA Appeals B.C. Supreme Court Ruling on Site C and Strongly Endorses B.C. Auditor General Performance Audit of Site C." Retrieved from http://www.newswire.ca/news-releases/pvla-appeals-bc-supreme-court-ruling-onsite-c--strongly-endorses-bc-auditor-general-performance-audit-of-site-c-518113251.html 
[41] Carlman, I. October 1984. "The Views of Politicians and Decision-Makers on Planning for the Use of Wind Power in Sweden." In Proceedings of the European Wind Energy Conference, Hamburg, Germany, Oct. 22-26, 1984.

[42] Cashore, B. 2002. "Legitimacy and the Privatization of Environmental Governance: How Non-State Market-Driven (NSMD) Governance Systems Gain Rule-Making Authority.” Governance 15(4): 503-529.

[43] Cashore, B., G. Auld, and D. Newsom. 2003. "Forest Certification (Eco-Labeling) Programs and Their Policy-Making Authority: Explaining Divergence Among North American and European Case Studies.” Forest Policy and Economics 5(3): 225-247.

[44] Cass, N., and G. Walker. 2009. "Emotion and Rationality: The Characterisation and Evaluation of Opposition to Renewable Energy Projects." Emotion, Space and Society 2(1): 62-69.

[45] Cayo, D. Dec. 10, 2014. "Demand for 'Social Licence' Stems From Distrust of Private and Public Institutions.” Calgary Herald. Retrieved from http://www.calgaryherald.com/ business/Cayo+Demand+social+licence+stems+from+distrust/10461249/story.html

[46] CBC News. Oct. 17, 2013. "RCMP, Protesters Withdraw After Shale Gas Clash in Rexton.” Retrieved from http://www.cbc.ca/news/canada/new-brunswick/rcmp-protesterswithdraw-after-shale-gas-clash-in-rexton-1.2100703

[47] CBC News. Oct. 17, 2013. "Wind Turbine Protest to Block Major Ontario Highway." Retrieved from http:/www.cbc.ca/news/canada/windsor/wind-turbine-protest-to-blockmajor-ontario-highway-1.2101075

[48] CBC News. June 11, 2014. "Northern Gateway Pipeline Approved: B.C. Reacts." Retrieved from http://www.cbc.ca/news/canada/british-columbia/northern-gatewaypipeline-approved-b-c-reacts-1.2672279

[49] CBC News. Nov. 10, 2014. "Neil Young Calls Pipeline Issues 'Scabs on People's Lives'." Retrieved from http://www.cbc.ca/news/canada/edmonton/neil-young-calls-pipelineissues-scabs-on-people-s-lives-1.2830170

[50] CBC News. April 24, 2015. "NEB CEO Peter Watson Heckled by Kinder Morgan Pipeline Protesters. Retrieved from http://www.cbc.ca/news/canada/british-columbia/nebceo-paul-watson-heckled-by-kinder-morgan-pipeline-protesters-1.3047773

[51] Chisholm, M. Jan. 15, 2013. "Former BC Hydro CEO condemns Enbridge's 'Bogus Economic' at Joint Review Panel.” Vancouver Observer. Retrieved from http://www. vancouverobserver.com/politics/former-bc-hydro-ceo-condemns-enbridges-boguseconomics-joint-review-panel

[52] Chisholm, M. May 6, 2014. "Citizens Unleash Constitutional Challenge Against Kinder Morgan NEB Pipeline Review." Vancouver Observer. Retrieved from http://www. vancouverobserver.com/news/citizens-unleash-constitutional-challenge-against-kindermorgan-neb-pipeline-review 
[53] Cohen, J. J., J. Reichl, and M. Schmidthaler. 2014. "Re-focussing Research Efforts on the Public Acceptance of Energy Infrastructure: A Critical Review.” Energy 76: 4-9.

[54] Compliance Coal Corporation. March 2, 2015. Letter to B.C. Associate Deputy Minister of Environment. Retrieved from http://a100.gov.bc.ca/appsdata/epic/documents/ p351/1425335959998_VTJhJ01cFfZPD3GhbYqm6gMyQsRmgptvywM2LPbCKZhyzl4D Q6db!1378338455!1425335740573.pdf

[55] Corscadden, K., A. Wile, and E. Yiridoe. 2012. "Social Licence and Consultation Criteria for Community Wind Projects.” Renewable Energy 44: 392-397.

[56] CSIRO. March 1, 2010. "Social Licence to Operate." Retrieved from http://www.csiro.au/ en/Research/MRF/Areas/Community-and-environment/Social-licence-to-operate.

[57] CTV News. Oct. 22, 2012. "Thousands Protest Northern Gateway Pipeline." Retrieved from http://www.ctvnews.ca/canada/thousands-protest-northern-gatewaypipeline-1.1005815

[58] Council of the Federation. July 2013. "Canadian Energy Strategy: Progress Report to the Council of the Federation." Retrieved from http://www.canadaspremiers.ca/ phocadownload/publications/cof_energy_strategy_2013_eng.pdf.

[59] Couture, T., and Y. Gagnon. 2010. "An Analysis of Feed-in Tariff Remuneration Models: Implications for Renewable Energy Investment.” Energy Policy 38(2): 955-965.

[60] Daniels v. Canada, 2016 SCC 12. Retrieved from https://scc-csc.lexum.com/scc-csc/scccsc/en/item/15858/index.do.

[61] Deephouse, D. L. 1996. "Does Isomorphism Legitimate?" The Academy of Management Journal 39(4): 1024-1039.

[62] Deephouse, David, and Marc Suchman. 2008. "Legitimacy in Organizational Institutionalism." The Sage Handbook of Organizational Institutionalism. Edited by Royston Greenwood, Christine Oliver, Kerstin Sahlin-Andersson, and Roy Suddaby. Thousand Oaks, CA: SAGE Publishing, 49-77.

[63] Deignan, B., E. Harvey, and L. Hoffman-Goetz. 2013. "Fright Factors About Wind Turbines and Health in Ontario Newspapers Before and After the Green Energy Act." Health, Risk \& Societ, 15(3): 234-250.

[64] del Rio, P., and M. Burgillo. 2008. "Assessing the Impact of Renewable Energy Deployment on Local Sustainability: Towards a Theoretical Framework.” Renewable and Sustainable Energy Reviews 12: 1325-1344.

[65] del Rio, P., and M. Burgillo, 2009. "An Empirical Analysis of Renewable Energy Deployment on Local Sustainability." Renewable and Sustainable Energy Reviews 13: 1314-1325.

[66] Delgamuukw v. British Columbia, [1997] 3 SCR 1010. Retrieved from http://scc-csc. lexum.com/scc-csc/scc-csc/en/item/1569/index.do 
[67] Delvaux, P. A. G., Y. Rabuteau, and K. Stanley. 2013. “Civil Society Involvement and Social Acceptability of Marine Energy Projects: Best Practices of the Marine Energy Sector.” MERiFIC: France.

[68] Dennis, Philip A. 1975. "The Role of the Drunk in a Oaxacan Village." American Anthropologist 77(4): 856-863.

[69] Denzau, Arthur T., and Douglass C. North. 1994. "Shared Mental Models: Ideologies and Institutions." Kyklos 47: 3-31.

[70] Devine-Wright, P. 2005. "Beyond NIMBYism: Towards an Integrated Framework for Understanding Public Perceptions of Wind Energy.” Wind Energy 8(2): 125-139.

[71] Devine-Wright, P. 2006. "Social Representations of Intermittency and the Shaping of Public Support for Wind Energy in the UK." International Journal of Global Energy Issues 25(3-4): 243-256.

[72] Devine-Wright, P. 2011. "Public Engagement with Large-Scale Renewable Energy Technologies: Breaking the Cycle of NIMBYism." Wiley Interdisciplinary Reviews: Climate Change 2(1): 19-26.

[73] Devine-Wright, P. 2011. "Place Attachment and Public Acceptance of Renewable Energy: A Tidal Energy Case Study.” Journal of Environmental Psychology 31(4): 336-343.

[74] Dinshaw, F. July 12, 2015. "David Suzuki Rescues Capsized Canoers at Site C Dam Protest." National Observer. Retrieved from http://www.nationalobserver.com/2015/07/12/ news/david-suzuki-rescues-capsized-canoers-site-c-dam-protest

[75] Doelle, D. 2009. "Role of Strategic Environmental Assessments in Energy Governance: A Case Study of Tidal Energy in Nova Scotia's Bay of Fundy.” Journal of Energy \& Natural Resources Law 27(2): 112-144.

[76] Canadian Council of Ministers of the Environment. 2009. Regional Strategic Environmental Assessment in Canada: Principles and Guidance. Winnipeg: Canadian Council of Ministers of the Environment.

[77] Doern, G. B., and M. Gattinger. 2003. Power Switch: Energy Regulatory Governance in the Twenty-First Century. Toronto: University of Toronto Press.

[78] Doern, G. B., M. Hill, M. Prince, and R. Schultz. 1999. Changing the Rules: Canada's Changing Regulatory Regimes and Institutions. Toronto: University of Toronto Press.

[79] Dorian, J. P., H. T. Franssen, and D. R. Simbeck. 2006. "Global Challenges in Energy." Energy Policy 34: 1984-1991.

[80] Douglas, Mary. 1966. Purity and Danger. New York: Routledge.

[81] Douglas, Mary. 1986. How Institutions Think. Syracuse: Syracuse University Press.

[82] Dowling, J., and J. Pfeffer. 1975. "Organizational Legitimacy: Social Values and Organizational Behavior.” Pacific Sociological Review 18: 122-136. 
[83] Dusyk, N. 2011. "Downstream Effects of a Hybrid Forum: The Case of the Site C Hydroelectric Dam in British Columbia, Canada." Annals of the Association of American Geographers 101(4): 873-881.

[84] Eisgruber, L. 2013. "The Resource Curse: Analysis of the Applicability to the Large-Scale Export of Electricity from Renewable Sources.” Energy Policy 57: 429-440.

[85] Eliesen, M. Oct. 30, 2014. "Letter of Withdrawal," Retrieved from https://docs.neb-one.gc.ca/ll-eng/llisapi.dll/fet ch/2000/90464/90552/548311/956726/2392873/2449925/2451033/2543157/C118-6-1_Marc_Eliesen_Letter_of_Withdrawal_-_A4E1Q6.pdf?nodeid=2543843\&vernum=-2

[86] Ellis, G., J. Barry, and C. Robinson. 2007. "Many Ways to Say 'No', Different Ways to Say 'Yes': Applying Q-Methodology to Understand Public Acceptance of Wind Farm Proposals." Journal of Environmental Planning and Management 50(4): 517-551.

[87] Ellis, G., R. Cowell, P. Strachan, J. Szarka, and C. Warren. 2009. "Wind Power: Is There a Planning 'Problem'?” Planning Theory and Practice 10: 521-547.

[88] Energy and Mines Ministers' Conference. 2012. “Toward Greater Pan-Canadian Collaboration: A Progress Report.” Retrieved from https:/www.nrcan.gc.ca/sites/www. nrcan.gc.ca/files/energy/files/pdf/EN_Energy\%20Progress\%20Report.pdf

[89] Energy Policy Institute of Canada. 2012, "A Canadian Energy Strategy Framework." Retrieved from http://www.canadasenergy.ca/canadian-energy-strategy/

[90] Environics Research Group. June 30, 2009. "Granting a Social Licence to Operate: Public Opinion and Mining in Remote/Rural Communities.” Retrieved from http://epe.lac-bac. gc.ca/100/200/301/pwgsc-tpsgc/por-ef/natural_resources/2009/086-08-e/report.pdf

[91] European Wind Energy Association. 2015. Wind in Power: 2014 European statistics. Retrieved from http://www.ewea.org/fileadmin/files/library/publications/statistics/EWEAAnnual-Statistics-2014.pdf

[92] Fallahnejad, M. H. 2013. "Delay Causes in Iran Gas Pipeline Projects.” International Journal of Project Management 31(1): 136-146.

[93] Fast, S. 2013. "Social Acceptance of Renewable Energy: Trends, Concepts, and Geographies." Geography Compass 7(12): 853-866.

[94] Fast, S., and W. Mabee, 2015. "Place-Making and Trust-Building: The Influence of Policy on Host Community Responses to Wind Farms.” Energy Policy 81: 27-37.

[95] Fekete, J. March 6, 2015. “"Minority' Using 'Social Licence' to Block Resource Projects, Joe Oliver Says.” Ottawa Citizen. Retrieved from http:/ottawacitizen.com/news/politics/ minority-using-notion-of-social-licence-to-try-to-block-resource-projects-joe-oliver-says

[96] Financial Post. Dec. 24, 2013. "Imperial Oil's Mackenzie Pipeline Pricetag Swells to \$20-billion." Retrieved from http://business.financialpost.com/news/energy/imperial-oilsmackenzie-pipeline-pricetag-swells-to-20-billion. 
[97] Fischer, F. 2000. Citizens, Experts, and the Environment: The Politics of Local Knowledge. Durham, NC: Duke University Press.

[98] Fort McKay First Nation v Alberta Energy Regulator, 2013 ABCA 355. Retrieved from http://www.canlii.org/en/ab/abca/doc/2013/2013abca355/2013abca355.html

[99] Fort Nelson First Nation Lands Department. June 17, 2015. "Dene Nation Speaks out on Proposed Controversial Regulations for Fracking: Multiple Presenters Stand in Line Late into Evening to Voice Concerns." Retrieved from http://lands.fnnation.ca/news/denenation-speaks-out-proposed-controversial-regulations-fracking-multiple-presenters-stand

[100] Fortin, M-J, A-S Devanne, et S. LeFloch. 2009. « L'acceptabilité sociale de l'éolien au Québec: Apprendre dans la turbulence. » Liaison Énergie-Francophonie, no. 7, Énergie et évaluation environnementale 83(2): 90-96. Retrieved from https://hal.archives-ouvertes.fr/ hal-00474561/document)

[101] Fortin, M-J, et Y. Fournis. 2014. « Vers une définition ascendante de l'acceptabilité sociale: Les dynamiques territoriales face aux projets énergétiques au Québec. » Natures Sciences Sociétés 22: 231-239.

[102] Fortin, Marie-José, and Sophie Le Floch. 2012. "Challenging Wind Turbine Projects in the Name of Landscape: Beyond 'Nimby,' Discussing the Development of Territories." Energy and Citizenship in Québec. Edited by Martin Pâquet and Stéphane Savard. 2343. New Perspectives in Québec Studies. Québec: Globe. Revue internationale d'études québécoises. Retrieved from http://www.erudit.org/livre/npqs/2012/003022co.pdf)

[103] Franks, Daniel M., and Tamar Cohen. 2012. "Social Licence in Design: Constructive Technology Assessment Within a Mineral Research and Development Institution." Technological Forecasting and Social Change 79(7): 1229-1240.

[104] Franks, D. M., R. Barnes, D. Brereton, T. Cohen, M. Garcia-Vasquez, T. Horberry, D. Lynas, B. McLellan, K. McNab, B. O. Santibáñez, and F. Weldegiorgis. 2013. Designing Mining Technology for Social Outcomes: Final Report of the Technology Futures Project. Prepared for CSIRO Minerals Down Under Flagship, Minerals Futures Cluster Collaboration, by the Centre for Social Responsibility in Mining \& the Minerals Industry Safety and Health Centre, Sustainable Minerals Institute, The University of Queensland. Brisbane. Retrieved from https://www.csrm.uq.edu.au/publications/designing-miningtechnology-for-social-outcomes-final-report-of-the-technology-futures-report-project.

[105] Garud, R., J. Gehman, and A. Karunakaran. 2014. "Boundaries, Breaches, and Bridges: The Case of Climategate." Research Policy 43(1): 60-73.

[106] Garus, K. 2015. “Denmark Breaks its Own Wind Record.” Sun and Wind Energy Magazine. Retrieved from http://www.sunwindenergy.com/wind-energy/denmark-breaksown-wind-record

[107] Gattinger, Monica, 2012. "Canada-United States Energy Relations: Making a MESS of Energy Policy.” American Review of Canadian Studies 42(4): 460-473. 
[108] Gehman, J., R. Garud, and L. K. Treviño. 2013. "Values Work: A Process Study of the Emergence and Performance of Organizational Values Practices." Academy of Management Journal 56: 84-112.

[109] Gendron, C. 2014. « Penser l'acceptabilité sociale : au-delà de l'intérêt, les valeurs. » Communiquer. Revue de communication sociale et publique, 117-129.

[110] Gibson, R. B., H. Benevides, M. Doelle, and D. Kirchhoff. 2010. "Strengthening Strategic Environmental Assessment in Canada: An Evaluation of Three Basic Options.” Journal of Environmental Law and Practice 20(3): 175-211.

[111] Gillingham, Kenneth, Richard G. Newell, and Karen Palmer. 2009. "Energy Efficiency Economics and Policy.” National Bureau of Economic Research working paper 15031. Retrieved from http://www.nber.org/papers/w15031.

[112] Gillis, D., June 18, 2013. “Enbridge Won’t Take ‘No' for an Answer, Despite 96\% Opposition.” The Common Sense Canadian. Retrieved from http://commonsensecanadian. ca/enbridge-wont-take-no-for-an-answer-despite-96-opposition/

[113] Glucker, A. N., P. P. J. Driessen, A. Kolhoff, and H. A. C. Runhaar. 2013. "Public Participation in Environmental Impact Assessment: Why, Who and How?" Environmental Impact Assessment Review 43: 104-111.

[114] Goulding, A. J. 2013. “A New Blueprint for Ontario’s Electricity Market.” Commentary, 389. Toronto: CD Howe Institute.

[115] Government of British Columbia. 2010. Bill 17 - 2010: Clean Energy Act. Retrieved from http://www.leg.bc.ca/39th2nd/1st_read/gov17-1.htm

[116] Government of British Columbia, Ministry of Finance. March 25, 2015. "Commitment to Finalize LNG Income Tax Framework Fulfilled." Information Bulletin, Retrieved from http://www2.news.gov.bc.ca/news_releases_2013-2017/2015fin0025-000399.htm

[117] Government of Canada. 1985. National Energy Board Act R.S.C., 1985, c. N-7. Retrieved from http://laws-lois.justice.gc.ca/eng/acts/N-7/FullText.html

[118] Government of Canada. Dec. 29, 2010. Land Claims Agreement Between the Inuit of Labrador and Her Majesty the Queen in Right of Newfoundland and Labrador and Her Majesty the Queen in Right of Canada, Indigenous and Northern Affairs Canada. Retrieved from http://www.aadnc-aandc.gc.ca/eng/1293647179208/1293647660333

[119] Government of Canada. Sept. 2, 2015. Justice Laws Website: Nunavut Land Claims Agreement Act (S.C. 1993, c. 29). Retrieved from http://laws-lois.justice.gc.ca/eng/ acts/N-28.7/page-1.html\#h-1

[120] Government of Canada. Sept. 2, 2015. Bill C-38, Jobs, Growth and Long-term Prosperity Act. Retrieved from http://www.parl.gc.ca/content/hoc/Bills/411/Government/C-38/C$38 \_4 / \mathrm{C}-38 \_4 . P D F$

[121] Government of Canada. Sept. 2, 2015. The James Bay and Northern Quebec Agreement. Retrieved from http://www.gcc.ca/pdf/LEG000000006.pdf 
[122] Government of Canada, Ministry of Finance. 2012. Jobs, Growth and Long-Term Prosperity: Economic Action Plan 2012. Ottawa: Her Majesty the Queen in Right of Canada.

[123] Government of Canada, Office of the Prime Minister, Minister of Natural Resources Mandate Letter, 2015, http://pm.gc.ca/eng/minister-natural-resources-mandate-letter

[124] Government of Canada, Jan. 27, 2016, "Government of Canada Moves to Restore Trust in Environmental Assessment," press release, retrieved from http://news.gc.ca/web/articleen.do? $\mathrm{mthd}=$ index\&crtr.page $=1 \&$ nid $=1029999$

[125] Government of New Brunswick, Office of the Premier. Dec. 18, 2014. "Government Introduces Moratorium on Hydraulic Fracturing in New Brunswick." Press release. Retrieved from http://www2.gnb.ca/content/gnb/en/news/news_release.2014.12.1404.html

[126] Government of Newfoundland \& Labrador, Ministry of Natural Resources. Oct. 10, 2014. "Minister Announces Independent Panel for Review of Hydraulic Fracturing," Retrieved from http://www.releases.gov.nl.ca/releases/2014/nr/1010n04.aspx

[127] Government of the Northwest Territories, Sept. 17, 2015. "Discussions on Hydraulic Fracturing Regulations to Continue into 18th Legislative Assembly." Retrieved from http://www.gov.nt.ca/newsroom/news/discussions-hydraulic-fracturing-regulationscontinue-18th-legislative-assembly.

[128] Graham, J. B., I. J. Smith, and J. R. Stephenson. 2009. "Public Perceptions of Wind Energy Developments: Case Studies from New Zealand," Energy Policy 237: 3348-3357.

[129] Gray, Earle. 2000. Forty Years in the Public Interest: A History of the National Energy Board. Vancouver/Toronto: Douglas \& McIntyre.

[130] Greenpeace. Sept. 2, 2015. "History and Mission.” Retrieved from http://www. greenpeace.org/usa/history-mission/

[131] Gunningham, Neil, Robert A. Kagan, and Dorothy Thornton. 2003. Shades of Green: Business, Regulation, and Environment. Redwood City, CA: Stanford University Press.

[132] Gunningham, N., R. A. Kagan, and D. Thornton. 2004. "Social Licence and Environmental Protection: Why Businesses Go Beyond Compliance.” Law \& Social Inquiry 29: 307-341.

[133] Haida Nation v. British Columbia (Minister of Forests), 2004 SCC 73. Retrieved from http://scc-csc.lexum.com/scc-csc/scc-csc/en/item/2189/index.do

[134] Hall, N. L., and T. Jeanneret. 2015. "Social Licence to Operate: An Opportunity to Enhance CSR for Deeper Communication and Engagement," Corporate Communications: An International Journal 20(2): 213-227.

[135] Han, S. H., S. Yun, H. Kim, Y. H. Kwak, H. K. Park, and S. H. Lee. 2009. "Analyzing Schedule Delays of Mega Project: Lessons Learned from Korea Train Express." IEEE Transactions on Engineering Management 56: 243-256. 
[136] Harris Decima. 2015. "Public Opinion Research on Energy Issues - Spring 20142015," prepared for Natural Resources Canada, Contract Number: 23483-150003/001/ CY, Retrieved from http://epe.lac-bac.gc.ca/100/200/301/pwgsc-tpsgc/por-ef/natural_ resources/2015/004-14-e/index.html.

[137] Harshaw, H. W. 2012. "British Columbia Oil and Gas Resource Management Opinion Survey 2011: Final Report." Vancouver, BC: University of British Columbia Faculty of Forestry.

[138] Healey, P. 2006. Collaborative Planning: Shaping Places in Fragmented Societies. New York: Palgrave Macmillan.

[139] Hepburn, G. 2009. “OECD Report: Alternatives to Traditional Regulation.” Retrieved from http://www.oecd.org/dataoecd/17/5/42245468.pdf.

[140] Herrmann, L. Jan. 11, 2012. "Canadian Resources Minister Calls Enviros 'Radical Groups'”, Digital Journal. Retrieved from http://www.digitaljournal.com/article/317726

[141] Higgs, G., R. Berry, D. Kidner, and M. Langford. 2008. "Using IT Approaches to Promote Public Participation in Renewable Energy Planning: Prospects and Challenges." Land Use Policy 25: 596-607.

[142] Hill, S. D., and J. D. Knott. 2010. "Too Close for Comfort: Social Controversies Surrounding Wind Farm Noise Setback Policies in Ontario." Renewable Energy Law \& Policy Review 153.

[143] Hindmarsh, R., and C. Matthews. 2008. "Deliberative Speak at the Turbine Face: Community Engagement, Wind Farms, and Renewable Energy Transitions in Australia." Journal of Environmental Policy and Planning 10(3): 217-232.

[144] Hoekstra, G. Feb. 5, 2014. "Majority of British Columbians Oppose Northern Gateway Pipeline: Poll." Vancouver Sun. Retrieved from http://www.vancouversun.com/technology/ Majority+British+Columbians+oppose+Northern+Gateway+pipeline+poll/9469513/story. html

[145] Howard-Grenville, J., C. Coglianese, and J. Nash. 2008. "Constructing the Licence to Operate: Internal Factors and Their Influence on Corporate Environmental Decisions." Law \& Policy 30: 73-107.

[146] Hu, Z., G. Pu, F. Fang, and C. Wang. 2004. "Economics, Environment, and Energy Life Cycle Assessment of Automobiles Fueled by Bio-Ethanol Blends in China." Renewable Energy 29(14): 2183-2192.

[147] Hughes, L. 2012. "A Generic Framework for the Description and Analysis of Energy Security in an Energy System.” Energy Policy 42: 221-231. doi: 10.1016/j.enpol.2011.11.079

[148] Institute for Energy Economics and Financial Analysis. October 2014. "Material Risks: How Public Accountability is Slowing Tar Sands Development." Retrieved from http:// www.ieefa.org/wp-content/uploads/2014/10/IEEFA.OCI_Material-Risks.compressed.pdf 
[149] International Energy Agency. 2014. World Energy Outlook 2014. Accessed Feb 11, 2015. Retrieved from http:/www.worldenergyoutlook.org/media/weo2010.pdf

[150] International Institute of Environment and Development. 2002. "Breaking New Ground: Mining, Minerals and Sustainable Development," ISBN 1-85383-907-8. Retrieved from http://pubs.iied.org/9084IIED.html.

[151] Ipsos Reid. 2012. "Public Opinion on the Environment 2012: Quantitative Report," prepared for Environment Canada, Contract \# K0A37-120024/001/CY. Retrieved from http://epe.lac-bac.gc.ca/100/200/301/pwgsc-tpsgc/por-ef/environment_canada/2012/00412-e/report/quant_report.pdf

[152] Jami, Anahita A. N., and P. R. Walsh. 2014. "The Role of Public Participation in Identifying Stakeholder Synergies in Wind Power Project Development: The Case Study of Ontario, Canada." Renewable Energy 68: 194-202.

[153] Jergeas, G. 2008. "Analysis of the Front-end Loading of Alberta Mega Oil Sands Projects," Project Management Journal 39(4): 95-104.

[154] Jobert, A., P. Laborgne, and S. Mimler. 2007. "Local Acceptance of Wind Energy: Factors of Success Identified in French and German Case Studies." Energy Policy 35(5): 27512760 .

[155] Jones, J. Dec. 23, 2013. “Mackenzie Valley’s New Price Tag: \$20-Billion (and rising).” Globe and Mail. Retrieved from http://www.theglobeandmail.com/report-on-business/ international-business/us-business/mackenzie-valleys-new-price-tag-20-billion-and-rising/ article16095114/.

[156] Joyce, S. and I. Thomson. 2000. "Earning a Social Licence to Operate: Social Acceptability and Resource Development in Latin America." CIM Bulletin 93(1037): 4953.

[157] Kagan, Robert A., Neil Gunningham, and Dorothy Thornton. 2003. "Explaining Corporate Environmental Performance: How Does Regulation Matter?" Law \& Society Review 37(1): 51-90.

[158] Keller, J. Nov. 14, 2014. 'First Nations Launch Federal Court Challenge of B.C.'s Site C Dam." Globe and Mail. Retrieved from http://www.theglobeandmail.com/news/britishcolumbia/first-nations-launch-federal-court-challenge-of-bcs-site-c-dam/article21568662/.

[159] Keller, J. Nov. 27, 2014. "Burnaby Mountain Protest Charges Dropped.” Huffington Post. Retrieved from http://www.huffingtonpost.ca/2014/11/27/burnaby-mountainprotest_n_6233274.html

[160] Kennedy, C. Feb. 27, 2015. "Snap Shot: How Some Industry Players are Using the Phrase 'Social Licence'.' The Social Licence website. http://thesociallicense.ca/snap-shot-howsome-industry-players-are-using-the-phrase-social-license 
[161] Kennedy, J., M. Ignasiak, and S. Duncanson. 2013. “Alberta First Nations Challenge Constitutionality of Federal Regulatory Reforms," Osler Blog. Retrieved from https://www.osler.com/en/resources/regulations/2013/alberta-first-nations-challengeconstitutionality.

[162] Kernaghan, Webb. 2005. "Sustainable Governance in the Twenty-First Century: Moving Beyond Instrument Choice." Designing Government: From Instruments to Governance. Edited by Pearl Eliadis et al. Montreal: McGill-Queen's University Press, 242-280.

[163] Kerr, S., J. Colton, F. Conway, A. Hull, K. Johnson, S. Jude, A. Kannen, S. MacDougall, C. McLachlan, T. Potts, J. Vergunst, and L. Watts. 2014. "Establishing an Agenda for Social Studies Research in Marine Renewable Energy.” Energy Policy 67: 694-702.

[164] Kostova, T., and S. Zaheer. 1999. “Organizational Legitimacy Under Conditions of Complexity: The Case of the Multinational Enterprise." Academy of Management Review 24: $64-81$.

[165] Lacey, J., and J. Lamont. 2014. "Using Social Contract to Inform Social Licence to Operate: An Application in the Australian Coal Seam Gas Industry." Journal of Cleaner Production 84: 831-839.

[166] Lahey, W. 2009. "Pillar 2 - Environmental Regulation of Energy Projects in Canada: Challenges and Solutions." Energy Framework Initiative. Retrieved from http://www.cga. ca/wp-content/uploads/2012/02/Pillar-2-Final-Paper-Laheyl.pdf

[167] Lamin, A., and S. Zaheer. 2012. "Wall Street vs. Main Street: Firm Strategies for Defending Legitimacy and Their Impact on Different Stakeholders." Organization Science 23: 47-66.

[168] Langford, M. 2008. Social Rights Jurisprudence: Emerging Trends in International and Comparative Law. Cambridge, U.K.: Cambridge University Press.

[169] Langniß, O., J. Diekmann, and U. Lehr. 2009. "Advanced Mechanisms for the Promotion of Renewable Energy - Models for the Future Evolution of the German Renewable Energy Act." Energy Policy 37(4): 1289-1297.

[170] Lavoie, J. July 3, 2014. "Site C Dam is Final Straw for B.C.'s Treaty 8 First Nations." Desmog Canada. Retrieved from http://www.desmog.ca/2014/07/03/site-c-final-straw-bcstreaty-8-first-nations

[171] Legislative Assembly of British Columbia. 2014. "Bill 4 - 2014: Park Amendment Act, 2014". Retrieved from http://www.leg.bc.ca/40th2nd/1st_read/gov04-1.htm

[172] Legislative Assembly of British Columbia. March 29, 2014. "Progress of Bills, $2^{\text {nd }}$ Session, $40^{\text {th }}$ Parliament." Retrieved from http://www.leg.bc.ca/40th2nd/votes/progress-of-bills.htm

[173] Leijon, M., M. Lindahl, A. Rehn, A. Skoglund, and R. Waters. 2010. "On the Physics of Power, Energy and Economics of Renewable Electric Energy Sources - Part I." Renewable Energy 35: 1729-1734. 
[174] Linnitt, C. May 2, 2014. "Tsleil-Waututh First Nation Announces Federal Legal Challenge Against Kinder Morgan Oil Pipeline Review Process.” DeSmog Canada. Retrieved from http://www.desmog.ca/2014/05/02/tsleil-waututh-first-nation-announces-legal-challengeagainst-kinder-morgan-oil-pipeline

[175] Logan, N. Sept. 23, 2014. "N.B. Election: Did Shale Gas and Fracking Sway the Vote?" Global News. Retrieved from http:/globalnews.ca/news/1577434/n-b-election-did-shalegas-and-fracking-sway-the-vote/

[176] Lui, E. April 11, 2014. “A Trip to New Brunswick to Learn About Shale Gas Development and What Communities are doing About it." Rabble. Retrieved from http://rabble.ca/ blogs/bloggers/making-waves/2014/04/trip-to-new-brunswick-to-learn-about-shale-gasdevelopment-and-w

[177] Lynch-Wood, Gary, and David Williamson. 2007. "The Social Licence as a Form of Regulation for Small and Medium Enterprises.” Journal of Law and Society 34: 321-341.

[178] Mabee, W. E., T. Carpenter, and J. Mannion. 2012. "Comparing the Feed-in Tariff Incentives for Renewable Electricity in Ontario and Germany." Energy Policy 40: 480489.

[179] MacDougall, S. 2015. "The Value of Delay in Tidal Energy Development," Energy Policy 87: 438-446.

[180] Maurer, J. G. 1971. Readings in Organization Theory: Open-System Approaches. New York: Random House.

[181] McCarthy, S. Jan. 27, 2016, “Ottawa adds Additional Steps to Pipeline Reviews," Globe and Mail. Retrieved from http://www.theglobeandmail.com/news/politics/liberals-toannounce-new-transition-rules-for-assessing-pipelines/article28412555/.

[182] McCrabb, R. Jan. 29, 2014. “\$500M Natural Gas Plant Planned for Middletown.” Dayton Daily News. Retrieved from http://www.daytondailynews.com/news/news/500m-naturalgas-plant-very-significant-developmen/nc5hW/.

[183] McDougall, John N. 1982. Fuels and the National Policy, Toronto: McClelland and Stewart.

[184] McMahon, Gary. 1998. "Mining and the Community: Results of the Quito Conference." Quito, Ecuador: The World Bank.

[185] Métis Nation of Ontario. 2015. "Part 3: Establishing a Métis Right - The Powley Test." Retrieved from http://www.Métisnation.org/harvesting/the-powley-story/establishing-aMétis-right---the-powley-test

[186] Meyer, J. W., and W. R. Scott. 1983. Centralization and the Legitimacy Problems of Local Government. Organizational Environments: Ritual and Rationality. Thousand Oaks, CA: SAGE Publishing, 199-215.

[187] Mikisew Cree First Nation v. Canada (Minister of Canadian Heritage). 2005 SCC 69. Retrieved from http://scc-csc.lexum.com/scc-csc/scc-csc/en/item/2251/index.do 
[188] Mikisew Cree First Nation v. Canada (Governor General in Council), 2014 FC 1244. Retrieved from http://www.usask.ca/nativelaw/documents/2014-fc-1244.pdf

[189] Miller, S., and D. Sequeira, D. 1998. Doing Better Business Through Effective Public Consultation and Disclosure: A Good Practice Manual, volume 1. International Finance Corporation. Retrieved from http:/wwwwds.worldbank.org/external/default/ WDSContentServer/IW3P/IB/1999/10/19/000094946_99093005545763/Rendered/PDF/ multi_page.pdf

[190] MiningFacts.org. "What is the Social Licence of Operate (SLO)?” Retrieved from http:// www.miningfacts.org/Communities/What-is-the-social-licence-to-operate/

[191] Moffat, K., and A. Zhang. 2014. "The Paths to Social Licence to Operate: An Integrative Model Explaining Community Acceptance of Mining." Resources Policy 39: 61-70.

[192] Morden, P. April 3, 2015. “Lambton County Wind Farm Approval Appealed.” Sarnia Observer. Retrieved from http://www.theobserver.ca/2015/04/03/wind-project-courtchallenge-continues

[193] Morgan, G. Nov. 4, 2014. "Cost of Keystone XL has Jumped Nearly 50\% During Six Years of Delays, Says TransCanada CEO.” National Post. Retrieved from http://business. financialpost.com/news/energy/cost-of-keystone-xl-has-jumped-nearly-50-during-sixyears-of-delays-says-transcanada-ceo.

[194] Morrison, John. 2014. The Social Licence: How to Keep Your Organization Legitimate. New York: Palgrave Macmillan.

[195] Mosher, J. N., and K. W. Corscadden. 2012. "Agriculture's Contribution to the Renewable Energy Sector: Policy and Economics - Do They Add Up?" Renewable and Sustainable Energy Reviews 16(6): 4157-4164.

[196] Mudasser, M., K. W. Corscadden, and E. K. Yiridoe. 2015. “Cost-Benefit Analysis of Grid-Connected Wind-Biogas Hybrid Energy Production, by Turbine Capacity and Site." Renewable Energy 80: 573-582.

[197] National Energy Board. April 2, 2014. "Ruling on Participation," Hearing Order OH-001-2014. Retrieved from https://docs.neb-one.gc.ca/ll-eng/llisapi.dll/fet ch/2000/90464/90552/548311/956726/2392873/2449981/2445932/A14-1___Letter_-_ Application_for_Trans_Mountain_Expansion_Project_-_Ruling_on_Participation_-_ A3V6I5.pdf?nodeid=2445819\&vernum=-2.

[198] National Energy Board. 2015. "National Energy Board Hearing Process Handbook." Retrieved from http://www.neb-one.gc.ca/prtcptn/hrng/hndbk/index-eng.html.

[199] National Energy Board. 2015. "Court Challenges To National Energy Board or Governor in Council Decisions.” Retrieved from http://www.neb-one.gc.ca/pplctnflng/crt/index-eng. html 
[200] Natural Resources Canada. 2012. “Canada’s Annual Energy and Mines Ministers' Conference - Energy.” Retrieved from https://www.nrcan.gc.ca/media-room/ backgrounders/2012/3283.

[201] Nelsen, Jacqueline Laura. 2007. "Social Licence to Operate : Integration into Mine Planning and Development." Master of Applied Science, University of British Columbia. Retrieved from http://hdl.handle.net/2429/31783.

[202] New Zealand Wind Energy Association. 2015. "New Zealand Wind Farms, Operating, Under Construction, Consented or Proposed.” New Zealand Wind Energy Association. Retrieved from http://www.windenergy.org.nz/mahinerangi-wind-farm

[203] Newman, D. November 2014. "Be Careful What You Wish for: Why Some Versions of 'Social Licence' are Unlicenced and may be Anti-Social." Macdonald Laurier Institute Commentary. Retrieved from http:/www.macdonaldlaurier.ca/files/pdf/ MLICommentaryNewmansociallicence1114webready.pdf.

[204] Nikiforuk, A. April 23, 2014. "No Cross-Exam in Trans Mountain Hearing Hurts NEB Credibility: Economist." The Tyee. Retrieved from http://www.thetyee.ca/ News/2014/04/23/No-Cross-Exam-Hurts-NEB-Credibility/

[205] Nimby Wars. 2009. “What is a Nimby?” Retrieved from http://nimbywars.com/what-is-animby

[206] Nordensvärd, J., and F. Urban. 2015. "The Stuttering Energy Transition in Germany: Wind Energy Policy and Feed-in Tariff Lock-in.” Energy Policy 82: 156-165.

[207] Northern Gateway. Sept. 2, 2015. Retrieved from http://www.gatewayfacts.ca/About-TheProject/Project-Overview.aspx

[208] Nymark, A., and J. Edge. 2010. “Competitiveness, Innovation and Regulatory Reform.” Regulatory Governance Initiative, Carleton University.

[209] O’Keefe, D. Dec. 15, 2014. "Energy East Lacks Social Licence: Trudeau.” Ricochet. Retrieved from https://ricochet.media/en/259/energy-east-lacks-social-licence-trudeau

[210] O’Neil, P. March 17, 2015. "Tom Mulcair Fights the Squeeze in Metro Vancouver Ridings." Vancouver Sun. Retrieved from http:/www.vancouversun.com/news/ Mulcair+fights+squeeze+Metro+Vancouver+ridings/10897656/story.html.

[211] Odeh, A. M., and H. T. Battaineh. 2002. "Causes of Construction Delay: Traditional Contracts.” International Journal of Project Management 20(1): 67-73.

[212] Oldreive, M. E. June 2013. "The Role of Strategic Environmental Assessments for Emerging Marine Renewable Energy Sectors: The Nova Scotian Example.” Journal of Environmental Assessment Policy and Management 15(02).

[213] Oliver, C. 1991. "Strategic Responses to Institutional Processes." Academy of Management Review 16: 145-179. 
[214] Ontario Energy Board. 2009. Getting to Know the Ontario Energy Board: Resource Guide for Regulated Utilities. Toronto: Ontario Energy Board.

[215] Ontario Power Authority \& Independent Electricity System Operator. 2013. Engaging Local Communities in Ontario's Electricity Planning Continuum: Enhancing Regional Electricity Planning and Siting. Retrieved from http://www.onregional-planning-andsiting-dialogue.ca/pdf/Regional_Planning-Siting_Report.pdf.

[216] Orangi, A., E. Palaneeswaran, and J. Wilson. 2011. "Exploring Delays in Victoria-Based Australian Pipeline Projects.” Procedia Engineering 14: 874-881.

[217] Orton, T. July 13, 2014. "BC Nature Files Legal Challenge Against Enbridge's Northern Gateway Pipeline." Business in Vancouver. Retrieved from https://www.biv.com/ article/2014/7/bc-nature-files-legal-challenge-against-enbridges-/.

[218] Owen, J. R., and D. Kemp. 2013. "Social Licence and Mining: A Critical Perspective." Resources Policy 38(1): 29-35.

[219] Panwar, N. L., S. C. Kaushik, and S. Kothari. 2011. "Role of Renewable Energy Sources in Environmental Protection: A Review." Renewable and Sustainable Energy Reviews 15(3): 1513-1524.

[220] Parsons, R., J. Lacey, and K. Moffat. 2014. "Maintaining Legitimacy of a Contested Practice: How the Minerals Industry Understands its 'Social Licence' to Operate." Resources Policy 41: 83-90.

[221] Parsons, R., and K. Moffat. 2014. “Constructing the Meaning of Social Licence." Social Epistemology 28(3-4): 340-363.

[222] Parsons, T. 1960. Structure and Process in Modern Societies. Free Press.

[223] Pasqualetti, M. J. 2011. "Social Barriers to Renewable Energy Landscapes." Geographical Review 101: 201-223.

[224] Pfeffer, J. 1981. "Management as Symbolic Action: The Creation and Maintenance of Organizational Paradigms." Research in Organizational Behavior 3: 1-52.

[225] Pfeffer, Jeffrey, and Gerald R. Salancik. 1978. The External Control of Organizations. New York: Harper \& Row.

[226] Pinch, Trevor J., and Wiebe E. Bijker. 1987. "The Social Construction of Facts and Artifacts: Or How the Sociology of Science and the Sociology of Technology Might Benefit Each Other." Social Construction of Technological Systems. Edited by Wiebe E. Bijker, Thomas P. Hughes, and Trevor J. Pinch. Cambridge: MIT Press, 17-50.

[227] Plourde, André. 2005. "The Changing Nature of National and Continental Energy Markets." Canadian Energy Policy and the Struggle for Sustainable Development. Edited by G. Bruce Doern. Toronto: University of Toronto Press, 51-82. 
[228] Plourde, A., and E. Whittingham. 2009. "Pillar 4 - A complicated Tale: Developing Energy in Canada is not a Simple Matter." Energy Framework Initiative. Retrieved from http://www.energyframework.ca/papers/pillar-4-social-license/?page=2

[229] Poitras, J. Dec. 22, 2014. “'Social Licence' Clouds Debates over Fracking, Pipelines.” CBC News. Retrieved from http://www.cbc.ca/news/canada/new-brunswick/sociallicence-clouds-debates-over-fracking-pipelines-1.2881039

[230] Potter, Ben. June 2014. “Opposition to Energy Projects Could Push up Bills,” Australian Financial Review. Accessed April 16, 2015, http://www.afr.com/markets/commodities/ energy/opposition-to-energy-projects-could-push-up-bills-20140601-ivntb

[231] Preprost, M. July 20, 2015. "Two First Nations Withdraw from Fight Against Site C Dam.” Business in Vancouver. Retrieved from https://www.biv.com/article/2015/7/twofirst-nations-withdraw-fight-against-site-c-da/

[232] Prystupa, M., and J. Uechi. Nov. 27, 2014. "RCMP Responds with Respect as Grand Chief Arrested on Burnaby Mountain.” Vancouver Observer. Retrieved from http:// www.vancouverobserver.com/news/grand-chief-stewart-phillip-prepares-arrest-burnabymountain

[233] R. v. Powley. 2003 SCC 43. Retrieved from http://scc-csc.lexum.com/scc-csc/scc-csc/en/ item/2076/index.do

[234] Raufflet, E., S. Baba, N. Delannon, and C. Perras. 2013. "Social Licence.” Encyclopedia of Corporate Social Responsibility. Edited by S. O. Idowu, N. Capaldi, L. Zu, and A. D. Gupta. New York: Springer, 2223-2230.

[235] Raven, R. P. J. M., R. M. Mourik, C. F. J. Feenstra, and E. Heiskanen. 2009. "Modulating Societal Acceptance in New Energy Projects: Towards a Toolkit Methodology for Project Managers." Energy 34: 564-574.

[236] Respecting Aboriginal Values and Environmental Needs, "Join the Circle - No Site C." Retrieved from http://raventrust.com/join-the-circle-no-site-c/.

[237] Ricci, M., P. Bellaby, and R. Flynn. 2010. "Engaging the Public on Paths to Sustainable Energy: Who has to Trust Whom?” Energy Policy 38: 2633-2640.

[238] Rindova, V. P., T. G. Pollock, and M. L. A. Hayward. 2006. "Celebrity Firms: The Social Construction Of Market Popularity." Academy of Management Review, 31: 50-71.

[239] Rio Tinto Alcan Inc. v. Carrier Sekani Tribal Council. 2010 SCC 43. Retrieved from http://scc-csc.lexum.com/scc-csc/scc-csc/en/item/7885/index.do

[240] Rivard, C., D. Lavoie, R. Lefebvre, S. Séjourné, C. Lamontagne, and M. Duchesne. 2014. "An Overview of Canadian Shale Gas Production and Environmental Concerns." International Journal of Coal Geology 126: 64-76.

[241] Rowland, R. April 13, 2014. “Kitimat Residents Vote 'No' in Pipeline Plebiscite.” Globe and Mail. Retrieved from http://www.theglobeandmail.com/news/british-columbia/ kitimat-residents-vote-in-northern-gateway-oil-pipeline-plebiscite/article17949815/ 
[242] Royal, R. 2008. “Community Consultation.” Renewable Energy Focus 9(1): 48-49.

[243] Sacred Trust Initiative. Sept. 2, 2015. About Sacred Trust. Retrieved from http:// twnsacredtrust.ca/

[244] Sambasivan, M., and Y. W. Soon. 2007. "Causes and Effects of Delays in Malaysian Construction Industry.” International Journal of Project Management 25(5): 517-526.

[245] Sandman, P. 2010. "Nimby," in Encyclopedia of Science and Technology Communication. Edited by Susanna Hornig Priest. Thousand Oaks, CA: SAGE Publishing. Retrieved from http://www.psandman.com/col/nimby.htm

[246] Sanoh, A., A. S. Kocaman, S. Kocal, S. Sherpa, and V. Modi. 2014. "The Economics of Clean Energy Resource Development and Grid Interconnection in Africa.” Renewable Energy 62: 598-609.

[247] Schaltegger, S., and R. Burritt. 2000. Contemporary Environmental Accounting: Issues, Concepts and Practice. Sheffield: Greenleaf Publishing, 111.

[248] Scott, W. Richard. 1995. Institutions and Organizations. Thousand Oaks, CA: SAGE Publishing.

[249] Sierra Club BC. June 16, 2015. "Opposition to Enbridge Grows since Federal Approval." Press release. Retrieved from http://www.sierraclub.bc.ca/media-centre/press-releases/ opposition-to-enbridge-grows-since-federal-approval

[250] Skolnick, T .J. Aug. 10, 2011. “Digging Deeper into New Brunswick's Fracking Controversy.” The Tyee. Retrieved from http://thetyee.ca/Blogs/ TheHook/Environment/2011/08/10/Digging-Deeper-Into-New-BrunswicksFracking/\#sthash.6QijdiTn.dpuf

[251] Sovacool, Benjamin K., and Ishani Mukherjee. 2011. "Conceptualizing and Measuring Energy Security: A Synthesized Approach.” Energy, PRES 2010, 36 (8): 5343-5355.

[252] Stanfield, S. March 4, 2015. "Raven Coal Mine Application Withdrawn." Comox Valley Record. Retrieved from http://www.comoxvalleyrecord.com/news/295050861.html.

[253] Stodalka, W. Sept. 20, 2015. “Judge Closes One Door, Opens Another on Site C Legal Challenge," Victoria Times Colonist. Retrieved from http:/www.timescolonist. com/business/judge-closes-one-door-opens-another-on-site-c-legal-challenge1.2063818\#sthash.fJoJ4baF.dpuf

[254] Stokes, L. C. 2013. “The Politics of Renewable Energy Policies: The Case of Feed-in Tariffs in Ontario, Canada.” Energy Policy 56: 490-500.

[255] Student Energy. 2015. Global Energy Literacy Research Project. Accessed March 30, 2015. Retrieved from: http://www.studentenergy.org/images/downloads/SE-GELRP.pdf

[256] Suchman, M. C. 1995. "Managing Legitimacy: Strategic and Institutional Approaches." Academy of Management Review, 20: 571-610. 
[257] Sustainable Business Council. Sept. 2, 2015. “Social Licence to Operate Paper.” Retrieved fromhttp://www.sbc.org.nz/_data/assets/pdf_file/0005/99437/Social-Licence-to-OperatePaper.pdf.

[258] Taku River Tlingit First Nation v. British Columbia (Project Assessment Director). 2004 SCC 74. Retrieved from http://scc-csc.lexum.com/scc-csc/scc-csc/en/item/2190/index.do

[259] Tarr, A. 2012. "Socio-Economic Opportunities and Challenges for Developing Community-Owned Small-Scale Tidal Energy in the Bras d'Or Lakes, Cape Breton." MBA research report. Cape Breton University: Nova Scotia.

[260] Teh-White, K. Nov. 10, 2011. "Social Licence to Operate is not Simply Theory but New Way to Manage.” Sydney Morning Herald. Retrieved from http://www.smh.com. au/business/social-licence-to-operate-is-not-simply-theory-but-new-way-to-manage20111109-1n7e8.html\#ixzz3jUoE8Azl

[261] Thomson, Ian, and Robert G. Boutilier. 2011. "Social Licence to Operate." SME Mining Engineering Handbook, $3^{\text {rd }}$ edition. Edited by P. Darling. Englewood, CO: Society for Mining, Metallurgy and Exploration, 1779-1796.

[262] Thomson, Ian, Robert Boutilier and Leeora Black. 2011. "The Social Licence to Operate: Normative Elements and Metrics." Presented at the First International Seminar on Social Responsibility in Mining, Santiago, Chile, October 2011.

[263] Thomson, I., R. G. Boutilier, J. Mamani and J. D. de Medina. 2010. “Starting It Right! Mineral Exploration and the Social Licence to Operate." Mining Law 4(2): 13-20.

[264] Thomson, Ian, and Susan Joyce. 2008. "The Social Licence to Operate: What it is and Why Does it Seem so Difficult to Obtain?" Presented at the Prospectors and Developers Association of Canada Convention, Toronto, Ontario, Canada, March 2008.

[265] Thornton, D., R. Kagan and N. Gunningham. 2003. "Sources of Corporate Environmental Performance.” California Management Review 46(1): 127-141.

[266] Thornton, Dorothy, Neil Gunningham, and Robert A. Kagan. Sept. 1, 2008. “Compliance Costs, Regulation, and Environmental Performance: Controlling Truck Emissions in the US.” Regulation \& Governance 2(3): 275-292.

[267] Thornton, D., N. Gunningham, and R. Kagan. 2009. "When Social Norms and Pressures Are Not Enough: Environmental Performance in the Trucking Industry." Law \& Society Review 43(2): 405-436.

[268] Tsilhqot'in Nation v. British Columbia. 2014 SCC 44. Retrieved from https://scc-csc. lexum.com/scc-csc/scc-csc/en/item/14246/index.do

[269] United Nations. 2008. "United Nations Declaration on the Rights of Indigenous Peoples." Retrieved from http://www.un.org/esa/socdev/unpfii/documents/DRIPS_en.pdf

[270] United Nations. 2013. "The United Nations Declaration on the Rights of Indigenous Peoples: A Manual for National Human Rights Institutions.” Retrieved from http://www. ohchr.org/Documents/Issues/IPeoples/UNDRIPManualForNHRIs.doc 
[271] United States Preventative Services Task Force. 2009. "Breast Cancer Screening." Retrieved from http://www.uspreventiveservicestaskforce.org/Page/Document/ UpdateSummaryFinal/breast-cancer-screening

[272] Van der Horst, D. 2007. "NIMBY or not? Exploring the Relevance of Location and the Politics of Voiced Opinions in Renewable Energy Siting Controversies.” Energy Policy, 35(5): 2705-2714.

[273] Vivian, A. June 19, 2015. "Fracking in the NWT." The Lawyers Weekly. Retrieved from http://lawyersweekly.ca/articles/2409

[274] Wakefield, J. April 20, 2015. "Site C Faces First Volley in Barrage of Legal Challenges." Alaska Highway News. Retrieved from http://www.alaskahighwaynews.ca/regional-news/ site-c/site-c-faces-first-volley-in-barrage-of-legal-challenges-1.1829269

[275] Walker, G., and N. Cass, 2007. "Carbon Reduction, 'The Public' and Renewable Energy: Engaging with Socio-Technical Configurations.” Area 39(4): 458-469.

[276] Walker, C., J. Baxter, and D. Ouellette. 2014. "Beyond Rhetoric to Understanding Determinants of Wind Turbine Support and Conflict in two Ontario, Canada Communities." Environment and Planning 46: 730-745.

[277] Washington, M., and E. J. Zajac. 2005. "Status Evolution and Competition: Theory and Evidence.” The Academy of Management Journal 48(2): 282-296.

[278] Watershed Sentinel. February 2012. “First Nations who Oppose Enbridge.” Retrieved from http://www.watershedsentinel.ca/content/first-nations-who-oppose-enbridge

[279] Watson, Peter. Nov. 21, 2014. "In the Eye of the Storm," Speech to the Economic Club of Canada, Canadian Energy Summit, Calgary, Alberta. Retrieved from https://www.nebone.gc.ca/bts/nws/spch/2014/nystrm/index-eng.html

[280] Watts, L. 2009. “Orkney Lab: An Archipelago Experiment in Futures. Imagining Landscapes. Edited by T. Ingold and M. Janowski. Retrieved from http://www.sand14. com/relocatinginnovation/download/watts_orkneylab_ingoldjanowski.pdf

[281] Watts, L. 2014. "Where Data is Made from a Numberless Sunset - The Work of a Poetic Ethnographer.” Retrieved from http://www.sand14.com/wpcontent/uploads/2014/10/ watts_poeticethnographer.pdf

[282] Watts, L., and B. Winthereik. 2014. "Energy as Alien.” New Energies: Land Art Generator Initiative, Copehagen. Edited by E. Monoian and R. Ferry. Retrieved from http://alienenergy.dk/wp-content/uploads/2014/10/EnergyAsAlien_PDF.pdf

[283] Weber, Max. 1922. Economy and Society: An Outline of Interpretive Sociology. Berkeley, CA: University of California Press.

[284] West, J., I. Bailey, and M. Winter. 2010. "Renewable Energy Policy and Public Perceptions of Renewable Energy: A Cultural Theory Approach.” Energy Policy 38, $5,739-5,748$. 
[285] Whatmore, S. J. 2009. "Mapping Knowledge Controversies: Science, Democracy and the Redistribution of Expertise," Progress in Human Geography 33(5): 587-598.

[286] Wiersma, B., and P. Devine-Wright. 2014. "Public Engagement with Offshore Renewable Energy: A Critical Review." Wiley Interdisciplinary Reviews: Climate Change 5: 493-507. doi:10.1002/wcc. 282.

[287] Wolsink, Maarten. Sept. 1, 2000. "Wind Power and the NIMBY-Myth: Institutional Capacity and the Limited Significance of Public Support." Renewable Energy 21: 49-64.

[288] Wolsink, Maarten. 2007. "Wind Power Implementation: The Nature of Public Attitudes: Equity and Fairness Instead of 'Backyard Motives.'. Renewable and Sustainable Energy Reviews 11: 1188-1207.

[289] World Wind Energy Association. 2014. World Wind Resource Assessment Report. WWEA Technical Paper Series (TP-01-14). Retrieved from http://www.wwindea.org/wpcontent/uploads/filebase/technology/WWEA_WWRAR_Dec2014_2.pdf.

[290] World Wind Energy Association. 2015. "New Record in Worldwide Wind Installations." Retrieved from http://www.wwindea.org/new-record-in-world wide-wind-installations/

[291] Wüstenhagen, R., M. Wolsink and M. J. Burer. 2007. "Social Acceptance of Renewable Energy Innovation: An Introduction to the Concept.” Energy Policy 35: 2683-2691.

[292] Zimmerman, M. A., and G. J. Zeitz. 2002. "Beyond Survival: Achieving New Venture Growth by Building Legitimacy.” Academy of Management Review 27(3): 414-431. 


\section{About the Authors}

John Colton is Professor of Sustainability and Community Development Studies at Acadia University. His research interests include sustainable community development, socio-economic impacts associated with renewable energy development, community engagement strategies, and aboriginal tourism and community development. He is coauthor of the Community and Business Toolkit for Tidal Energy Development and the Tidal Energy Community Engagement Handbook. He is a founding member of the Acadia Tidal Energy Institute.

Kenneth Corscadden is an electrical engineer with over 20 years academic and industrial research experience. He has held senior industrial research positions with a range of companies and has managed projects around the world with applications in energy conservation, primarily in pulp and paper industry. His academic career includes positions at Acadia University and Dalhousie University where he is currently the Associate Dean Research and Graduate Studies. His research program covers a range of projects that consider energy efficiency, sustainability and the implementation of renewable resources. He is also interested in the interaction and the impact of energy policy on socioeconomics of renewable energy. Applications include agriculture, high volume production and instrumentation and control.

Stewart Fast is a Senior Research Associate at the Institute for Science, Society and Policy at the University of Ottawa and a Fellow of the Queen's Institute for Energy and Environmental Policy. His major research focus relates to public and community engagement with energy infrastructure."

Monica Gattinger is Director, of the Institute for Science, Society and Policy, Chair of Positive Energy, and an Associate Professor in the School of Political Studies at the University of Ottawa. Monica specializes in energy policy and governance, and arts and cultural policy, and her expertise is regularly sought out by private, public and civil society leaders at the domestic and international levels. She is a member of the Editorial Boards of the University of Ottawa Press and the journal Canadian Public Administration.

Joel Gehman is Assistant Professor of Strategic Management \& Organization at the University of Alberta School of Business. His research examines how global sustainability concerns affect organizational strategies, technology innovation, and regulatory requirements, and reciprocally, how organizations, innovation and regulations affect global sustainability concerns. He graduated from Cornell University (BS) and the Pennsylvania State University (PhD). You can find him on Twitter@joelgehman.

Martha Hall Findlay is an Executive Fellow and Director of the Digital Economy Program at the School of Public Policy, University of Calgary. She is Chair of the Advisory Council for Positive Energy, member of the Advisory Council of the New York Global Leaders Dialogue, and served as Chair of the Advisory Council of the Partnership for Resource Trade. Martha was twice elected as a Member of Parliament, served as Official Opposition Critic and was a member of several House of Commons Standing Committees. Martha has over 25 years of business, legal and corporate governance experience (domestic as well as international) with major multi-national corporations as well as start-ups, primarily in telecommunications, fintech and international trade.

Dylan Morgan holds a PhD in environmental economics from the University of Ottawa, which he completed in 2014. His primary research interests are the policy and economic implications of environmental subsidies and the effects that publically available pollution information has on firm level environmental performance. Dylan currently resides in Ottawa where he works as an analyst and policy advisor for Environment and Climate Change Canada.

Kekinusuqs, Judith Sayers is a Strategic Adviser to First Nations and Corporations and provides advice on many issues including relationship building and negotiating equitable agreements. She is an adjunct professor with the University of Victoria's Gustavson School of Business. Judith is the former Chief of the Hupacasath First Nation located in Port Alberni, BC.

Jennifer Winter is an Assistant Professor of Economics and Director of Energy and Environmental Policy at The School of Public Policy, University of Calgary. Her research is focused on the effects of government regulation and policy on the development of natural resources and energy, and the consequences and trade-offs of energy development. Jennifer is actively engaged in increasing public understanding of energy and environmental issues, and was recognized for this with a 2014 Young Women in Energy Award.

Adonis Yatchew is Professor of Economics at the University of Toronto and Editor-in-Chief of the Energy Journal. He completed his undergraduate work in mathematics and economics at the University of Toronto, and his Ph.D. in economics at Harvard University. He has held visiting appointments at Trinity College, Cambridge, the University of Chicago and Australian National University, among others. His graduate level text Semiparametric Regression for the Applied Econometrician was published by Cambridge University Press. He has advised public and private sector companies on energy, regulatory and other matters for over 25 years and has provided testimony in numerous regulatory and litigation procedures. Adonis Yatchew currently teaches undergraduate and graduate courses in energy economics, graduate courses in econometrics, and 'Big Ideas' courses on energy in the School of Environment. 


\title{
ABOUT THE SCHOOL OF PUBLIC POLICY
}

The School of Public Policy has become the flagship school of its kind in Canada by providing a practical, global and focused perspective on public policy analysis and practice in areas of energy and environmental policy, international policy and economic and social policy that is unique in Canada.

The mission of The School of Public Policy is to strengthen Canada's public service, institutions and economic performance for the betterment of our families, communities and country. We do this by:

- Building capacity in Government through the formal training of public servants in degree and non-degree programs, giving the people charged with making public policy work for Canada the hands-on expertise to represent our vital interests both here and abroad;

- Improving Public Policy Discourse outside Government through executive and strategic assessment programs, building a stronger understanding of what makes public policy work for those outside of the public sector and helps everyday Canadians make informed decisions on the politics that will shape their futures;

- Providing a Global Perspective on Public Policy Research through international collaborations, education, and community outreach programs, bringing global best practices to bear on Canadian public policy, resulting in decisions that benefit all people for the long term, not a few people for the short term.

Our research is conducted to the highest standards of scholarship and objectivity. The decision to pursue research is made by a Research Committee chaired by the Research Director and made up of Area and Program Directors. All research is subject to blind peer-review and the final decision whether or not to publish is made by an independent Director.

\author{
The School of Public Policy \\ University of Calgary, Downtown Campus \\ 906 8th Avenue S.W., 5th Floor \\ Calgary, Alberta T2P $1 \mathrm{H} 9$ \\ Phone: 4032103802
}

\section{DISTRIBUTION}

Our publications are available online at www.policyschool.ca.

\section{DISCLAIMER}

The opinions expressed in these publications are the authors' alone and therefore do not necessarily reflect the opinions of the supporters, staff, or boards of The School of Public Policy.

\section{COPYRIGHT}

Copyright (C) 2016 by The School of Public Policy.

All rights reserved. No part of this publication may be reproduced in any manner whatsoever without written permission except in the case of brief passages quoted in critical articles and reviews.

\section{DATE OF ISSUE \\ May 2016}

\section{MEDIA INQUIRIES AND INFORMATION}

For media inquiries, please contact Morten Paulsen at 403-220-2540. Our web site, www.policyschool.ca, contains more information about The School's events, publications, and staff.

\section{DEVELOPMENT}

For information about contributing to The School of Public Policy, please contact Paul Beaudry by telephone at 403-220-4624 or by e-mail at paul.beaudry1@ucalgary.ca.

\section{ISSN}

1919-112x SPP Research Papers (Print)

1919-1138 SPP Research Papers (Online) 


\section{RECENT PUBLICATIONS BY THE SCHOOL OF PUBLIC POLICY}

THE OPENING OF THE NORTHERN SEA ROUTES: THE IMPLICATIONS FOR GLOBAL SHIPPING AND FOR CANADA'S RELATIONS WITH ASIA http://policyschool.ucalgary.ca/?q=content/opening-northern-sea-routes-implications-global-shipping-and-canadas-relations-asia Hugh Stephens | May 2016

\section{EFFICIENT METROPOLITAN RESOURCE ALLOCATION (TECHNICAL PAPER)}

http://policyschool.ucalgary.ca/?q=content/efficient-metropolitan-resource-allocation-technical-paper Richard Arnott | May 2016

\section{MACROPRUDENTIAL POLICY: A SUMMARY}

http://policyschool.ucalgary.ca/?q=content/macroprudential-policy-summary Alfred Lehar and Mahdi Ebrahimi Kahou | May 2016

THE VALUE PROPOSITION OF PREVENTION: THE IMPACTS OF PURE NORTH S'ENERGY FOUNDATION'S PREVENTIVE CARE PROGRAM ON ACUTE CARE UTILIZATION IN ALBERTA

http://policyschool.ucalgary.ca/?q=content/value-proposition-prevention-impacts-pure-north-s\%E2\%80\%99energy-foundation\%E2\%80\%99spreventive-care-progra

J.C. Herbert Emery | April 2016

\section{A SURVEY OF THE LITERATURE ON LOCAL CONTENT POLICIES IN THE OIL AND GAS INDUSTRY IN EAST AFRICA \\ http://policyschool.ucalgary.ca/?q=content/survey-literature-local-content-policies-oil-and-gas-industry-east-africa Chilenye Nwapi | April 2016}

\section{MAKE THE ALBERTA CARBON LEVY REVENUE NEUTRAL}

http://policyschool.ucalgary.ca/?q=content/make-alberta-carbon-levy-revenue-neutral Kenneth McKenzie | April 2016

IT'S NOT JUST ABOUT BABY TEETH: PREVENTING EARLY CHILDHOOD CARIES

http://policyschool.ucalgary.ca/?q=content/it\%E2\%80\%99s-not-just-about-baby-teeth-preventing-early-childhood-caries Jennifer Zwicker, Carolyn Dudley and Herbert Emery | April 2016

A MAJOR SETBACK FOR RETIREMENT SAVINGS: CHANGING HOW FINANCIAL ADVISERS ARE COMPENSATED COULD HURT LESS-THAN-WEALTHY INVESTORS MOST

http://policyschool.ucalgary.ca/?q=content/major-setback-retirement-savings-changing-how-financial-advisers-are-compensated-could-hurtPierre Lortie | April 2016

THE THEORY AND EVIDENCE CONCERNING PUBLIC-PRIVATE PARTNERSHIPS IN CANADA AND ELSEWHERE http://policyschool.ucalgary.ca/?q=content/theory-and-evidence-concerning-public-private-partnerships-canada-and-elsewhere Anthony Boardman, Matti Siemiatycki and Aidan Vining | March 2016

THE COSTLIEST TAX OF ALL: RAISING REVENUE THROUGH CORPORATE TAX HIKES CAN BE COUNTER-PRODUCTIVE FOR THE PROVINCES http://policyschool.ucalgary.ca/?q=content/costliest-tax-all-raising-revenue-through-corporate-tax-hikes-can-be-counter-productive-prov Bev Dahlby and Ergete Ferede | March 2016

\section{CUTTING PROVINCIAL CORPORATE INCOME TAX RATES TO PROMOTE INVESTMENT, EMPLOYMENT AND ECONOMIC GROWTH}

http://policyschool.ucalgary.ca/?q=content/cutting-provincial-corporate-income-tax-rates-promote-investment-employment-and-economic-gro Bev Dahlby and Ergete Ferede | March 2016

INTO THE MIRE: A CLOSER LOOK AT FOSSIL FUEL SUBSIDIES

http://policyschool.ucalgary.ca/?q=content/mire-closer-look-fossil-fuel-subsidies Radoslaw Stefanski | March 2016 